De trabajadores a proveedores.

\title{
La Responsabilidad Social Empresarial y la tercerización laboral en los ingenios azucareros
}

\author{
María Camila Jiménez Nicholls \\ Trabajo de grado para optar por el título de socióloga
}

Directora:

Natalia Teresa Berti

Universidad del Rosario

Escuela de Ciencias Humanas

Bogotá 


\section{Tabla de contenido}

A. Introducción: El Valle del Cauca y la agroindustria de la caña de azúcar ....5

A.1. Tercerización laboral y Responsabilidad Social Empresarial. Contexto conceptual .11

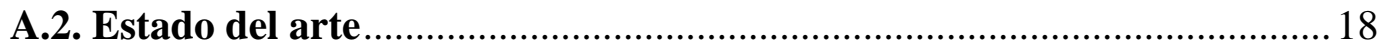

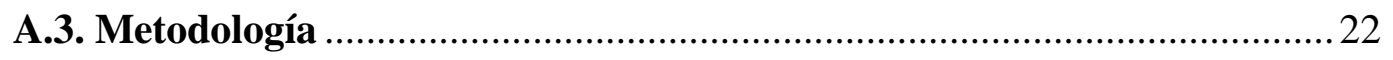

B. Capítulo 1. Paternalismo y neoliberalismo: dos ejes para el análisis de las condiciones de vida y trabajo en los ingenios.

B.1. Paternalismo como eje de análisis de la relación obrero-patronal y sus

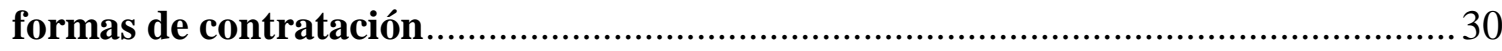

B.1.1. El paternalismo y su contexto político nacional ............................... 31

B.1.2. Condiciones de vida y de trabajo durante la etapa de paternalismo en los ingenios.

B.2. Neoliberalismo como proyecto político y económico: nuevos cambios en

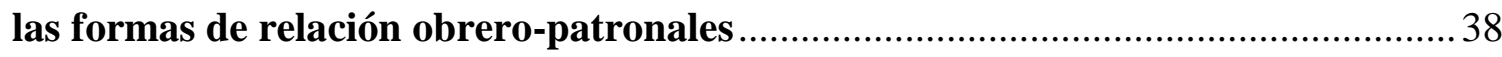

B.2.1. Contexto nacional del neoliberalismo............................................ 38

B.2.2. Relación estado-industria azucarera............................................... 40

B.2.3 Legislación que permite la tercerización .......................................... 41

C. Capítulo 2. Relaciones laborales: ingenios, sindicatos y corteros de caña....44

C.1. Construcción de narrativas de otredad e ingenios como agentes

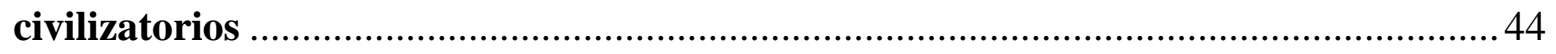

C.1.1 Corteros y el oficio de cortar de caña ............................................. 45

C.1.2. Narrativas de otredad basadas en imaginarios de analfabetismo, manejo del dinero, vicios y sus familias.

C.2. De relación laboral a relación comercial: los ingenios y los corteros.....51

C.2.1. Las distintas formas de contratación en el proceso de tercerización laboral y los paros del 2005 y 2008 .52 
C.2.2. El establecimiento de la relación comercial: Servicios de Cosecha Dorado

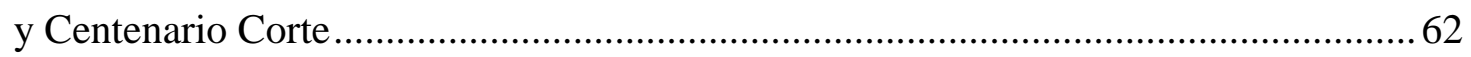

C.2.3. Pacto Global como respuesta a la crisis corteros-ingenios ....................65

C.3. Asociación colectiva o Representación..................................................66

D. Capítulo 3. Responsabilidad social empresarial .................................... 72

D.1. Paternalismo o RSE: continuidades, rupturas, grupos de interés y

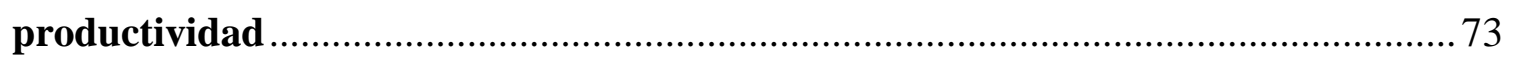

D.1.1. Del paternalismo tradicional a la burocratizada RSE: las rupturas y continuidades .74

D.1.2. Los efectos adversos que dejan las distintas formas de relación entre el

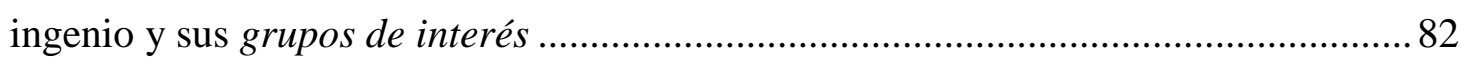

D.2. La RSE una arena en disputa ................................................... 90

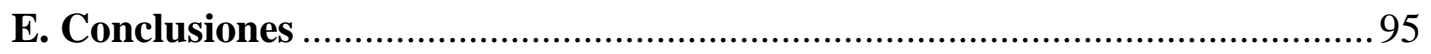

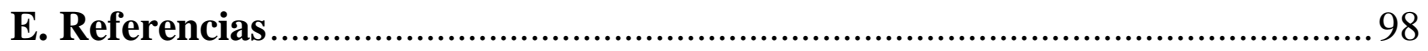

\section{Listado de ilustraciones}

Ilustración 1 Capilla del Ingenio Pichichí ............................................................. 7

Ilustración 2 Foto de un Calambuco tomada de Boliviatours (s/f) .......................... 36

\section{Listado de Tablas}

Tabla 1: Ingenio El Centenario-Cantidad de trabajadores

Tabla 2: Ingenio El Centenario-Tipo de contratación

Tabla 3: Ingenio El Centenario- Trabajadores discriminados por sexo

Tabla 4: Ingenio El Dorado-Cantidad de Trabajadores

Tabla 5: Ingenio El Dorado- Trabajadores discriminados por sexo 
Tabla 6: Entrevistas a profundidad

Tabla 7: Ingenios y empresas de corte

Tabla 8: Ingenios, empresas de corte y sindicatos

\section{Índice de abreviaciones}

CGT Confederación General del Trabajo

CTA Cooperativas de trabajo asociado

CTC Confederación de Trabajadores de Colombia

CUT Central Unitaria de Trabajadores

EAT Empresas asociativas de trabajo

GRI Global Reporting Initiative

RSE Responsabilidad Social Empresarial

SAS Sociedades Anónimas Simplificadas

TLC Tratado de Libre Comercio 


\section{De trabajadores a proveedores. La Responsabilidad Social Empresarial y la tercerización laboral en los ingenios azucareros}

\section{A. Introducción: EI Valle del Cauca y la agroindustria de la caña de azúcar}

La agroindustria de la caña de azúcar se ubica en el valle geográfico del río Cauca. Esta región comprende el norte del departamento del Cauca, la cuenca que atraviesa el Valle del Cauca y el sur del departamento de Risaralda. Por las características de los suelos de las distintas regiones se presentan rendimientos diferenciados. Por ejemplo, en el norte del Cauca se produce "entre 90 a 100 toneladas de caña por hectárea a diferencia de las zonas de acá del Valle del Cauca, que son más privilegiados, donde los promedios están entre 120 y 140 toneladas por hectárea" (Andrés Casto, presidente de un sindicato de industria: 21 de julio de 2015). Por esta razón, el salario de los corteros en el departamento del Cauca puede ser menor en comparación a los corteros del Valle, "en el corte de caña es más fácil ganarse 500 mil pesos acá en el Valle del Cauca que ganárselos allá” (Andrés Casto: 21 de julio de 2015).

Hoy en día la industria azucarera está integrada por catorce ingenios, que para el año 2000 empleaban de forma directa a 28.018 personas, 12.000 menos que en 1980 (ONU y CEPAL, 2002) ${ }^{1}$. Doce de ellos asociados a Asocaña y dos no asociados, en total disponen de 238.204 hectáreas cultivadas de caña de azúcar, de este total el 25\% de los terrenos pertenece a los 14 ingenios y el otro $75 \%$ de los terrenos es de 2750 proveedores de caña ${ }^{2}$, materia prima fundamental para la industria que produce azúcar, mieles y sus derivados, además son productores de bioetanol y son cogeneradores de energía eléctrica. Para el año 2016 se produjeron: 2,4 millones de toneladas de azúcar; 434.431 litros de bioetanol como parte del programa gubernamental de oxigenación de las gasolinas en Colombia que entró en vigencia en el año 2005; y $1.417 \mathrm{GWh}$ aprovechadas por la industria y $592 \mathrm{GWh}$ vendidas a la red nacional de energía ${ }^{3}$ (Asocaña, 2017).

\footnotetext{
${ }^{1}$ Los datos de la ONU y la CEPAL no permiten analizar si la disminución de 12 mil puestos de trabajo es por procesos de tercerización laboral o porque efectivamente se disminuyeron los puestos de trabajo asociados a esta industria.

${ }^{2}$ La mayoría de los productores o agricultores están afiliados a Procaña.

${ }^{3}$ Según Asocaña (2014) la cogeneración es un procedimiento mediante el cual se produce de forma simultánea energía eléctrica, mecánica y térmica. Esto se logra utilizando el bagazo de la caña, lo que queda al extraerle sus jugos, como combustible para alimentar sus calderas y utilizar el vapor como energía para el funcionamiento de sus procesos.
} 
La industria azucarera actual tiene como antecedente la aparición de los trapiches y la molienda de la caña, cuando Santiago Eder en la Hacienda La Rita inició un cultivo cafetero y más tarde en los mismos terrenos fundó el Ingenio Manuelita hacia 1901. Después de la instalación del ingenio Manuelita en el Valle del Cauca, de la construcción del ferrocarril al Pacífico y del Canal de Panamá se generaron buenas condiciones para que se instauraran más ingenios en la región (Rojas 2017).

Hacia la segunda mitad del siglo XX la industria azucarera se consolidó con la constitución de varias entidades (Rojas 2017). La primera fue Asocaña que en 1959 se constituyó como entidad gremial. Hoy agrupa casi todos los ingenios y tiene como objetivo fortalecer el poder de negociación de sus asociados con el estado y empresas en el ámbito internacional. En 1961 se constituyó la Comercializadora Internacional de Azúcares y Mieles (Ciamsa) encargada de coordinar las exportaciones e importaciones de la industria azucarera colombiana. Después, en 1973, los cultivadores de caña se asociaron a través de Procaña una entidad de carácter gremial, sin ánimo de lucro, que ejerce la representación de las personas naturales o jurídicas que cultivan caña de azúcar (Procaña, sd).

En 1977 se creó Tecnicaña, agremiación de los profesionales y técnicos del sector. En el mismo año se estableció Cenicaña, una corporación privada sin ánimo de lucro, por iniciativa de Asocaña como un centro de investigación y asesoramiento técnico para el cultivo de caña de azúcar. Esta es la entidad encargada de desarrollar nuevas variedades de caña, más productivas, más precoces en su cosecha y más resistentes a las enfermedades, así como control de plagas y enfermedades, análisis de los suelos, entre otros (Rojas 2017). Este complejo empresarial ha sido determinante en el desarrollo de la industria y de la población vallecaucana.

Hasta hace poco los ingenios azucareros en su interior albergaban pequeños pueblos que contaban con servicios como medicina, agua potable, electricidad, teléfono, transporte, educación y hasta capilla. En el Dorado, por ejemplo, vivían el dueño y su familia, los trabajadores y empleados junto a sus familias, las monjas y el padre. La fábrica de procesamiento del azúcar compartía el terreno con una pequeña escuela, la capilla, el barrio, el teatro y un par de casinos. Hoy los ejecutivos, y la mayoría de trabajadores y empleados, se trasladaron a vivir a las ciudades, pero quedaron testimonios arquitectónicos de lo que 
fueron estos pueblitos. Todavía se ven algunos trapiches, casi abandonados o que ya no cumplen su función original, y grandes arboledas que adornan las vías de acceso.

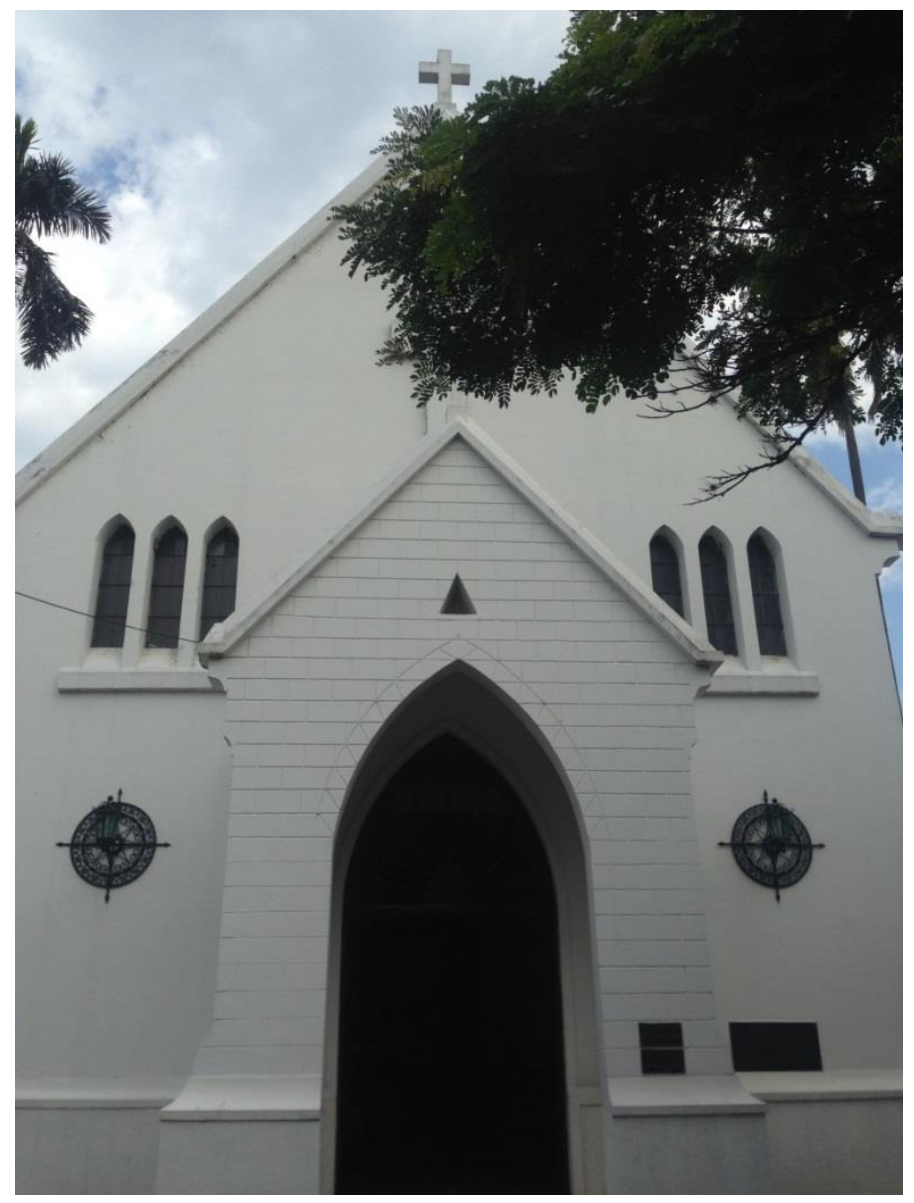

Ilustración 1 Capilla del Ingenio Pichichí

A mediados del siglo pasado, el personal dedicado al corte de caña y sus familias, muchas de ellos afro-descendientes provenientes del Pacífico, vivían en condiciones poco dignas en campamentos construidos por los ingenios. Hasta hace pocos años, las empresas transportaban a los corteros desde sus casas a las plantaciones, hacinados en camiones que los recogían iniciando la aurora y los dejaban al caer la tarde. Los calambucos originales, vagones o la carcasa de un bus remolcado por un tractor, han sido reemplazados recientemente por buses comunes. Eran duras condiciones de vida, como dura ha sido su labor.

El oficio del cortero sigue siendo arduo y exigente físicamente. Los corteros ostentan los más altos índices de accidentalidad y enfermedades entre los trabajadores rurales. Este 
oficio desaparecerá lentamente puesto que la industria le está apostando a la mecanización del corte, para no depender del factor humano, resentido por las difíciles condiciones de vida, en que se desenvuelven (Adolfo Madrid, abogado laboralista del sector azucarero: 27 de julio de 2017). Los propios corteros no quieren que sus hijos continúen en esta actividad y por ello luchan para que sus hijos puedan recibir una educación que les permita un trabajo menos exigente físicamente (Adolfo Madrid: 27 de julio de 2017).

A pesar de algunos cambios sustanciales en la calidad de vida de los corteros, en comparación a sus condiciones durante el establecimiento de la industria, hoy en día continúan los problemas como la tercerización laboral y la fragmentación del colectivo de trabajadores. Esta relación ha presentado cambios significativos con la introducción de contratos tercerizados por medio de las CTA, los contratos sindicales, contratistas, entre otros y empresas de corte permitidos por la legislación laboral. En este contexto, la primera década de los 2000 estuvo marcada por dos grandes conflictos laborales entre los ingenios y los corteros de caña. Los paros del 2005 y del 2008 resultaron siendo hitos que cambiaron no solo la vida de los corteros y sus familias sino también la de la industria azucarera en general.

Después de los conflictos obrero-patronales de la década pasada, los ingenios tomaron medidas para hacerle frente a las críticas de la sociedad civil y a la publicidad negativa al adherirse al Pacto Global, iniciativa voluntaria de Naciones Unidas. Es decir, no enfrentaron dicha crisis a través de los canales preestablecidos de relaciones industriales o recursos humanos, sino que decidieron renovar sus formas de relacionarse con los distintos actores asociados a la industria. Dicha renovación iba enfocada a establecer cambios en los programas sociales que la industria había realizado a través de la iglesia; donde las soluciones se basaron en la construcción de vivienda y en la educación de los trabajadores y sus hijos.

Este pasaje de modelos paternalistas a la RSE consiste en una organización tecnocrática y burocratizada de beneficios "extra-salariales" que las empresas (y el estado) no reconocen como derechos que los trabajadores podrían alcanzar con sueldos y condiciones de trabajo dignas. La adscripción al Pacto Global implicó la revisión de antiguas ayudas sociales personalizadas y arbitrarias, manejadas por el patrón y la iglesia; la instalación de nuevas áreas de bienestar social al interior de los ingenios; y la consecuente reorganización de la relación de los ingenios con sus colaboradores, proveedores, accionistas y la comunidad. 
Todo lo cual se sistematiza para comunicar anualmente a la comunidad nacional e internacional sobre los resultados alcanzados por medio de los programas con fines específicos dirigidos por profesionales. De esta forma las empresas se blindan de las críticas frente a la situación laboral de los corteros y buscan evadir legislaciones y controles más rigurosos por parte del estado.

De hecho, los nuevos programas de RSE han ayudado a legitimar la presencia de la agroindustria en esta región, bajo los programas de asistencia social. Según Rojas (2012) por medio de dichos programas los ingenios han logrado mostrar la cara amable de la industria a través de la inversión en la educación. Se convierte en lo que el autor llama "el buen vecino" que fortalece su presencia en la región y por tanto imposibilita los cuestionamientos; las empresas cumplen un rol de benefactores, "en lugares en los que la presencia del estado ha sido históricamente escasa y en los que los empresarios no siempre mostraron su cara amable" (Rojas 2012, 29).

Es en este contexto de altos niveles de precarización laboral y de implementación de nuevas formas de relación obrero patronal relacionadas con la RSE y la vinculación al Pacto Global como respuesta a la crítica de la sociedad civil al accionar de los ingenios pretendo responder a la pregunta ¿cómo opera la responsabilidad social empresarial en un contexto de altos niveles de tercerización laboral?

Frente a las protestas los ingenios han utilizado diferentes mecanismos que les permiten "la imposición de estrategias que posibilitan la intermediación, y de paso la no existencia de relaciones laborales directas con las personas que trabajan en distintos procesos, condenando a los trabajadores a precarias condiciones laborales" (Rojas 2012, 19). Esta estrategia facilita la fragmentación del conjunto de los trabajadores, en especial los corteros de caña de azúcar, al diferenciar formas de contratación directas e indirectas y generar espacios de negociación separados.

Asimismo, los ingenios han combinado esta estrategia con modelos de responsabilidad social empresarial (en adelante RSE), los cuales, al igual que las antiguas prácticas paternalistas, desplazan la disputa por mejores condiciones de vida y de trabajo a un terreno despolitizado donde los conflictos entre las empresas y sus actores de interés se gestionan por medio de formularios y procedimientos previamente pautados que no dan lugar 
a la protesta o confrontación abierta. Al mismo tiempo, evitan la confluencia de las demandas de los trabajadores - directos e indirectos - y de la comunidad. No obstante, en el contexto de precarización laboral de la mano de la tercerización, algunos trabajadores tercerizados y la sociedad civil resignifican la RSE como una nueva arena de disputa en la cual aprenden a tramitar de manera efectiva sus demandas por mejores condiciones de vida y de trabajo.

En este sentido, se revisan los conceptos de RSE y tercerización laboral; se presentan los estudios previos sobre la industria azucarera en la región a fin de ubicar los aportes de esta investigación desde el campo de la sociología; y se exponen los métodos y técnicas utilizados. Luego se desarrollan tres capítulos y las conclusiones.

El primer capítulo tiene como objetivo exponer cómo el paternalismo, como una relación particular obrero-patronal asociado a ciertas formas de contratación, y el neoliberalismo, como proyecto político-económico, han producido cambios en las condiciones de vida y de trabajo de los trabajadores de la industria azucarera y la legislación que fundamenta los nuevos cambios en los tipos de contratación.

El segundo capítulo tiene como propósito mostrar el proceso de precarización laboral al que fueron sometidos los corteros de caña desde su salida de los ingenios, donde eran trabajadores directos, hasta las nuevas formas de contratación por medio de sociedades anónimas, ahora como proveedores de caña de los ingenios, así como los hitos que han marcado dichas transformaciones. Además, explicar el papel que jugaron los sindicatos como un tercer actor activo de esta relación sobre todo durante y después de los paros.

El tercer capítulo se enfoca en la configuración de la RSE y tiene como objetivo exponer cómo opera la RSE, qué continuidades o rupturas existen entre este aspecto de la nueva forma de relación obrero-patronal y el paternalismo, así como el tratamiento diferenciado a sus grupos de interés a través de los indicadores propios del Global Reporting Initiave (GRI). Además, ver cómo los corteros resignifican la RSE y la convierten en una arena de disputa para acceder a mejores condiciones de vida y de trabajo. 


\section{A.1. Tercerización laboral y Responsabilidad Social Empresarial. Contexto conceptual}

Para responder a la pregunta ¿cómo opera la responsabilidad social empresarial en un contexto de altos niveles de tercerización laboral? se proponen dos conceptos para desarrollar el contexto conceptual: la tercerización laboral y la responsabilidad social empresarial.

\section{Tercerización laboral: una manifestación de la precariedad laboral en América Latina}

Los procesos de tercerización de los corteros de caña que se viven en Colombia y específicamente en la industria azucarera hacen parte de un proceso más amplio de precarización laboral en todo el continente americano. La precariedad laboral debe ser entendida tanto en un contexto espacial como temporal, "en su complejidad como síntoma de los cambios y mutaciones en la dinámica e interior del patrón de acumulación capitalista, y como parte de una respuesta del capital a su propia crisis" (Vejar 2014, 151). Asimismo, la precariedad debe entenderse en el contexto desigual de la estructura productiva latinoamericana donde resaltan la subcontratación, el subempleo, la subocupación, la sobre cualificación como formas predominantes en el mundo del trabajo lo cual genera trabajadores de diferentes estratos donde unos están en desventaja frente a otros (Vejar 2014).

La precarización además debe ser entendida en una temporalidad asociada al desarrollo del capitalismo, que avanza de manera desigual en cuanto al movimiento, la dirección y el contenido. En ese sentido la precariedad laboral surgió en el contexto de neoliberalización en América Latina como una forma de disciplinar la fuerza de trabajo y se asocia a la fragilidad, escasez, insatisfacción, degradación y erosión del trabajo; asimismo se combina con una larga historia de degradación, pérdida y prolongación de una falta en el trabajo que dejó la promesa no cumplida del estado de bienestar. La instauración del paradigma neoliberal en América Latina dicta nuevas formas de precarización que no son mejores o peores a las anteriores, simplemente, son diferentes (Vejar 2014).

En ese sentido la Escuela Nacional Sindical (2014) da otros parámetros adicionales para entender la precariedad en el contexto colombiano, más allá de la contextualización espacio-tiempo del problema. La Escuela expone que el trabajo precario va mucho más allá de no tener un salario bajo que no le permita acceder a bienes y servicios necesarios para una vida digna. Para esto se basa en principios de la OIT que permiten esbozar que el trabajo 
precario implica una carencia de un ingreso social y de múltiples tipos de seguridad laboral por parte de los trabajadores precarizados.

El ingreso social refuerza el grado de seguridad de quienes trabajan y se compone de las siguientes características: la auto-producción, es decir, la alimentación, bienes y servicios producidos por sí mismos; el salario o pago que recibe por su labor productiva; el apoyo de la familia o comunidad local; los beneficios de la empresa generalmente derivados de una convención colectiva o de dádivas ofrecidas por el empleador a algunos empleados (un ejemplo de esto son los programas de RSE que brindan los ingenios); los beneficios del estado, la seguridad social, asistencia social, transferencias estatales, subsidios estatales, entre otras; y por último, los beneficios derivados de los ahorros e inversiones privados (Escuela Nacional Sindical 2014, 13).

Según la Escuela Nacional (2014) los niveles de precariedad laboral “dependen del grado en que se puede unir cada uno de estos componentes. Obviamente, el ingreso social puede variar entre trabajadores que tienen el mismo puesto de trabajo y tipo de contrato laboral, cuando esto existe” (Escuela Nacional Sindical 2014, 13). Este grado de precariedad puede aumentar si el derecho a la asociación colectiva, estipulado en el convenio 87 de la OIT, no es efectivo. Pues esto incapacita a los trabajadores a que puedan satisfacer sus demás derechos laborales, "debido a que el derecho a organizarse y tener una voz colectiva es un derecho habilitante que ayuda a garantizar los procedimientos que mitigan el desequilibrio de poder inherente en la relación de empleo" (Escuela Nacional Sindical 2014, 14).

En ese contexto, según Basualdo y Morales (2014), la tercerización laboral es una estrategia de las organizaciones empresariales en la cual una empresa establece un contrato con terceros y les confía el cumplimiento de actividades que pueden ser de apoyo o periféricas. No obstante "los límites entre actividades principales y secundarias suelen ser arbitrarios, difusos y relativos" (Basualdo \& Esponda 2014, 23). La tercerización laboral para el suministro de mano de obra temporal, establece lo que la OIT nombra relaciones triangulares.

En otras palabras, esta modalidad permite establecer contratos entre la empresa beneficiaria y la empresa proveedora para emplear trabajadores que serán puestos a disposición de la empresa beneficiaria, “quien definirá y supervisará las tareas del personal 
suministrado. Asimismo, será quien determine si el personal va a desempeñarse en locales propios o externos". En caso de que dichos trabajadores laboren en los terrenos de la empresa beneficiaria, la empresa proveedora "tendrá una actuación secundaria y se limitará a pagar los salarios" (Basualdo \& Esponda 2014, 23). Esto delega a las empresas proveedoras los riesgos y responsabilidades propios de la contratación directa de personal, tales como, negociar con el sindicato, pagar indemnizaciones por despidos, resolver problemas de ausentismo, etc.

En esta relación de tipo triangular se establece un contrato comercial entre dos empresas la beneficiaria y la subcontratista, la subcontratista a la vez establece contratos de tipo laboral con sus trabajadores. Entre la empresa beneficiaria y los trabajadores continúa existiendo una relación con contenido laboral pero sin las obligaciones que por ley se establecen (Basualdo \& Morales 2014). En la industria azucarera en Colombia en las primeras décadas del 2000 se observan distintas formas de tercerización laboral, pero algunas delegan más responsabilidades en los corteros que otras. En ese sentido se pueden mencionar los contratos sindicales, las empresas asociativas de trabajo (EAT), las cooperativas de trabajo asociado (CTA), los contratistas, entre otras. En todos los casos las empresas proveedoras son responsables de conseguir los corteros y pagarles los costos propios de un contrato laboral, mientras que los ingenios siguen dirigiendo el corte de caña.

Adicionalmente, en el contexto particular de los corteros de caña de azúcar, es imposible desligar el tema de la precarización y la tercerización laboral sin tener en cuenta el concepto de raza, pues en su mayoría los corteros de caña son afro-descendientes y eso ha dado pie a la construcción de narrativas de otredad basadas en imaginarios de raza y clase que refuerzan el uso de la subcontratación como estrategia corporativa. En algunos casos, haciendo uso de estos imaginarios, se justifican los fracasos de las distintas formas de subcontratación pasando a los trabajadores tercerizados la carga de la culpa y desligando, al menos de manera discursiva, la responsabilidad de los ingenios que son los culpables de las condiciones precarias.

Según Restrepo (2013) la especificidad de este proceso de racialización radica en la formación de dos sujetos políticos, un nosotros y un ellos, y unas subjetividades en nombre de la existencia, supuesta o efectiva, de un grupo étnico. Así, entiende etnización “como el 
proceso en el cual unas poblaciones son constituidas y se constituyen como grupo étnico", se produce la diferencia cultural (Restrepo 2013, 15). Un proceso de coproducción e inscripción de otros, diferentes/marcados, y nosotros, diferentes/no-marcados, en un entramado social de exclusiones e inclusiones propias de la dialéctica de reproducción/contestación permanente de la hegemonía y subalternidad (Restrepo 2002, 35).

La tercerización y precarización laboral además están presentes en una época de establecimiento de lo que Dolan y Rajak (2016) llaman la gramática de la RSE que no opera solamente en un nivel retórico, sino que de hecho utiliza herramientas prácticas y discursivas que se movilizan con el fin de contener la oposición lo cual le permite a las compañías sobrevivir y a la vez expandirse. Y en este contexto de subcontratación estas autoras afirman que la RSE sirve para reforzar, en vez de desafiar, las jerarquías existentes o el statu-quo; al tiempo que otorga a las empresas un mecanismo de protección que paradójicamente trabaja para limitar (en lugar de extender) su responsabilidad ética y desplazar el riesgo hacia los contratistas.

\section{Responsabilidad social empresarial}

El paternalismo, según Valero (2013), puede ser entendido como un instrumento de control que se inspiró en valores arcaicos opuestos a los principios de la modernidad como la libertad y la autonomía. Quien ejerce poder, aporta protección y deferencia, a cambio de lealtad y obediencia. Esto, según Valero (2013) genera una interacción en doble vía entre empresario y trabajador. Desde la RSE, aunque a través de estrategias de recolección de datos y reporte de los mismos por medio de indicadores, se retoman antiguos hábitos paternalistas con los que "se espera lograr que los sometidos sean leales, agradecidos y pasivos" (Valero 2013, 31). En este escenario los beneficios que se brindan desde la RSE, así como las distintas expresiones de bondad patronal, dejan efectos adversos de control de la vida del trabajador. Esto es una evidencia de que la RSE es una continuación del paternalismo en cuanto a los efectos adversos que dejan. Que para Valero (2013), dadas las condiciones en que se producen esas prácticas, son también una calculada obsequiosidad que corresponde a propósitos de control social, legitimidad de la autoridad y mejor manejo de la fuerza de trabajo. 
Según Valero (2013) en cuanto a los cambios con el periodo clásico paternalista, en la era de la RSE el empresario como un sujeto individual ha sido reemplazado por un equipo de técnicos especializados que bajo una lógica de cálculo optan por relaciones directas y personalizadas con los trabajadores. Aunque subordinada a estrategias de costos y beneficios, vinculadas a planes productivos empresariales y mediadas por códigos, protocolos, directrices y normas, el conjunto de beneficios concedido a los trabajadores es tratado como extraordinario y destacable y por tanto se vuelve susceptible de ser divulgado frente a trabajadores y a la comunidad en general.

La RSE se instala en la industria azucarera a inicios de la segunda década del 2000 con la adhesión de varios ingenios a la iniciativa de Naciones Unidas denominada Pacto Global y permite reelaborar la relación obrero-patronal paternalista en el contexto de la tercerización laboral. Esto se asocia a la instalación o reforma de las áreas de Relaciones Industriales y/o de Recursos Humanos desde las cuales se aprovecha "cualquier ocasión para dejar la impronta de los valores fundamentales (cuidadosamente seleccionados) de la organización en sus empleados" (Willmott 2007).

En el contexto de tercerización, la RSE se instala en los ingenios y tiene como característica primordial el carácter voluntario. El cual para Banerjee (2008) es una muestra de que los intereses de los inversionistas al mostrar sus corporaciones como sostenibles o responsables, son una evidencia de la necesidad de evadir controles legales o legislación más fuerte por parte de los estados donde operan. Un ejemplo de esto son los lineamientos promovidos desde el Consejo Empresarial Mundial para el Desarrollo Sostenible: mantener la libertad empresarial a través de iniciativas voluntarias en vez de la coerción regulatoria o normativa (Banerjee 2008, 66).

El carácter voluntario de la RSE se mantiene a través de la instalación de lo que Benson y Kirsch (2010) llaman culturas de auditoria ${ }^{4}$. En el caso de comercio de diamantes estudiado por Cross (2016) la cultura de la auditoria permite a las empresas mostrarse como como buenos ciudadanos corporativos con un buen rendimiento normativo; mientras les permite reafirmar su compromiso con el libre mercado como es requerido por sus

\footnotetext{
${ }^{4}$ Audit Culture (Benson \& Kirsch 2010).
} 
sightholders ${ }^{5}$. La instalación de dichos mecanismos faculta a los actores dominantes de las industrias minimizar o limitar su exposición a la publicidad negativa, al tiempo que asegura que sus prácticas en las cadenas de suministro permanezcan "competitivas" (Cross 2016, 116).

El punto fundamental es la forma en que se realizan las auditorias asociadas a la RSE pues fabrican una ilusión de transparencia, por medio de prácticas performativas y coreográficas, que muestran tanto como ocultan. Esto se convierte en un performance que reproduce las condiciones que la auditoría describe (Dolan y Rajak 2016, 14). En ese sentido, la voluntariedad es un continuo, entre el paternalismo y la RSE puesto que son beneficios que se "perciben como parte de la liberalidad y concesión que discrecionalmente se concede; prevalece la idea de que se trata de una costumbre y una dádiva, más que un derecho o norma institucionalizada" (Valero 2013, 350). No obstante ahora se presenta con objetivos a cumplir, grupos a beneficiar, se hacen seguimientos, evaluaciones y se audita. La RSE tiene formas más sofisticadas de entregar y conceder beneficios a sus grupos de interés.

El problema radica en que los beneficios que reciben los colaboradores y otros grupos de interés al no haber sido adquiridas por medio de negociaciones sindicales o pactos colectivos, no representan un derecho para el trabajador, por tanto pueden ser retiradas cuando los ingenios lo consideren pertinente. La RSE al ser voluntaria y al evitar la coerción estatal está atada a discreción del empleador lo cual deja sin defensa legal a los trabajadores y a la sociedad civil. Esto es una similitud con el paternalismo, sin embargo en la RSE esto se comunica de una manera particular, ya no se trata solamente de evitar conflictos laborales y disciplinar (civilizar) a la mano de obra, y convencer al estado de su importancia y asegurar cierta protección de mercado interno, sino que también incluye una comunicación con la comunidad nacional e internacional que de paso ayuda al acceso a los mercados externos e internos.

Además, la RSE a través de sus indicadores, como los del GRI, e informes logran mostrar a las compañías como responsables, al tiempo que externalizan o desplazan sus

\footnotetext{
${ }^{5}$ Es una forma de contrato a tiempo definido, utilizada por el grupo De Beers, con clientes conocidos como Sightholders. Estos clientes se encuentran entre los principales vendedores y procesadores de diamantes en el mundo. Quienes a su vez deben de pasar por ciertos procesos para llegar a estar en el grupo de empresas proveedoras reconocidas por De Beeers (Cross 2016).
} 
obligaciones hacia las cadenas de suministro (Dolan \& Rajak 2016); y de esta manera se establecen diferencias en los beneficios que brindan a los distintos grupos de interés. Por lo tanto no todos se benefician por igual, por ejemplo no tienen los mismos beneficios un colaborador que un proveedor. En ese sentido, la promesa de inclusión para algunos indefectiblemente trae consigo el costo de exclusión, precariedad y pérdida de derechos para otros.

Esto es una muestra de la contradicción fundamental implícita en la RSE, la capacidad discursiva de permitirle a las corporaciones reafirmar y desplazar, simultáneamente, responsabilidades. Que además se evidencia en el mutuo ascenso de la RSE y la subcontratación como estrategias corporativas (Dolan \& Rajak 2016). Este trato diferenciado en el paternalismo operaba diferente, pero también lograba fragmentar al conjunto de los trabajadores (al aseado y honrado que merecía recibir ciertos tratos y al molesto y contestatario que no). Pero la forma en que se hace desde la RSE es más efectiva porque se entrecruza con las formas de contratación: trabajadores directos e indirectos.

El proceso de reportar todo lo que se realiza en el ingenio en los informes de sostenibilidad anuales a través de indicadores y otros procedimientos pasa por la estandarización de las personas a través de procesos y categorías. Procesos por medio de los cuales se logra traducir, interpretar o medir sujetos humanos o territoriales para hacerlos más visibles, más legibles y gobernables (Scott 1998). Este proceso según Dolan y Rajak (2016) muestra que las tecnologías de la RSE también pretenden hacer legibles los sujetos por medio de protocolos estandarizados y lineamientos de las buenas prácticas donde se incorpora una ética supra cultural para gobernar espacios y actores divergentes, llevándolos al campo regulatorio y moral de las corporaciones (Dolan \& Rajak 2016).

En las reestructuraciones productivas y ajustes de las últimas décadas el paternalismo ha demostrado que tiene la capacidad de cambiar y mutar en diferentes estructuras sociales “desde el rol de la benevolencia personalizada de los pioneros de las primeras fábricas [...] hasta las modalidades que hoy coexisten con discursos y metodologías de la llamada RSE" (Valero 2013, 16). En contra de la idea de que este había llegado a su fin con la modernización de las relaciones laborales, existen ciertos contextos donde ha demostrado la capacidad de resurgir, adaptarse y resistir al cambio. En las similitudes entre el antiguo y el neo 
paternalismo asociado a la RSE se encuentra la "idea de desplegar políticas de integración y bienestar orientadas a conjurar la organización autónoma de los trabajadores; lo anterior dentro de un manejo de amplia discrecionalidad y protagonismo empresarial" (Valero 2013, 346).

\section{A.2. Estado del arte}

En el estudio de la industria azucarera se destacan dos grandes vertientes: una económicoadministrativa y otra sociológica, histórica y antropológica. Desde las ciencias económicoadministrativas se resaltan temas como el establecimiento de la industria azucarera junto a ciertas instituciones asociadas que facilitaron su desarrollo (Ramos 1996; Posada y Posada 1996; Alacevich 2010); después hay un salto desde el establecimiento de la industria hasta la época más reciente, y los estudios se enfocan en la cantidad y calidad de empleos que genera el "conglomerado azucarero" (ONU y CEPAL 2002; Arbeláez, Estacio y Olivera 2010); el impacto de la producción de biodiesel en la región (MME y BID 2012); y la instalación de la RSE en la industria azucarera (Ronderos 2011).

Desde la sociología, la antropología y la historia los estudios de la industria azucarera se enfocan en las dinámicas en las plantaciones y las implicaciones de la división social del trabajo (Mintz 1974; 1980), el despojo legal para hacerse con la tierra y la proletarización de los campesinos negros (Taussig y Rubbo 2011 [1975]; Taussig 2010 [1980]), la instalación de la agroindustria y los factores que influyeron en su crecimiento (Rojas 2017; Rojas 2014), el peso del sindicalismo en la segunda mitad del siglo XX (Hurtado y Urrea-Giraldo 2004), la desregulación del mercado (Urrea-Giraldo 2010), la precariedad laboral (Pérez \& Álvarez 2009), la tercerización laboral y paros de corteros (Urrea-Giraldo 2007; Aricarpa 2006; López-Durango 2014) el género y las corteras de caña (Lasso-Ortega 2015) y la raza (Rojas 2012; Rojas 2006). A diferencia de la primera que se enfoca en el caso de Puerto Rico, el resto trabaja el caso colombiano.

Desde las ciencias económicas Ramos (1996), antiguo directivo de Asocaña, explica que el establecimiento y concentración de la industria azucarera en el Valle del Cauca, se debió a la suspensión de importaciones de azúcar, asociada a la política de sustitución de importaciones de Lleras Restrepo. Para el autor una posible reforma agraria y huelgas de trabajadores de varios de los ingenios llevaron a que los empresarios formaran una asociación 
gremial en 1959. Según Posada y Posada (1966) el establecimiento de la Corporación Autónoma Regional del Valle del Cauca (CVC) en 1954 benefició a la industria, pues desde dicha corporación se impulsaron proyectos de electrificación de la región cultivada de caña y la adecuación del río Cauca que permitieron extender en más de 80.000 hectáreas los terrenos aptos para su cultivo. No obstante, estas acciones terminaron afectando y secando los humedales de las madres viejas del rio Cauca afectando la diversidad de fauna y flora propia de esos ecosistemas.

Ya en el 2000 la ONU y la CEPAL (2002) explicaron que se estableció un conglomerado bajo un modelo de desarrollo hacia adentro que condujo al establecimiento de grandes empresas con "una fuerte integración vertical, alto número de empleos, abultados gastos de mantenimiento, y escasos niveles de sinergia o complementariedad entre ellos. Un ejemplo propio del modelo de producción fordista" (ONU y CEPAL 2002, 18). Sin embargo, estos autores reducen el concepto de producción fordista a la organización técnica del trabajo y no consideran los aspectos normativos y las prácticas en las relaciones obrero-patronales que permitieron esa organización en otras latitudes.

Otro estudio de la primera década del 2000 analiza la producción de bioetanol o diésel a partir de la caña de azúcar, el Ministerio de Minas y Energía y el BID (2012) analizaron los impactos que su producción ha tenido en la región. Para esto se cita un estudio que realizó la OIT en el 2004 sobre el ingenio Mayagüez donde resaltan la contratación por medio de los contratos sindicales. Además en el informe se explica entre otras, que la adhesión a las CTA era abierta y voluntaria, existe participación democrática de todos los asociados y el ingenio no les impone directrices, políticas ni reglamentos. Estas dos formas de contratación de los corteros, y otras que no menciona el informe, permitieron la precarización de los trabajadores y después de las protestas de esta primera década fueron abolidas por la alta precarización laboral.

Por último, dentro de este grupo de estudios se resalta el análisis de la RSE en términos laborales, fiscales y ambientales realizado por Ronderos (2011). Con respecto al tema laboral para el momento de su estudio, las cooperativas de trabajo asociado (en adelante CTA) seguían siendo la forma de contratación predominante que además permitieron a las empresas evadir el pago de ciertas prestaciones estipuladas por la ley. Según el autor, las empresas azucareras estaban exentas de la responsabilidad de velar por los beneficios 
derivados de la legislación laboral vigente en materia salarial y prestacional de los corteros.

Ahora bien, entre los estudios realizados desde la antropología, la sociología y la historia se destaca Mintz (1985) quien analiza el impacto que tuvo la producción de azúcar en América y Europa y cómo este producto pasó de ser un lujo a una necesidad del día a día. El autor realizó dos etnografías (Mintz 1974; Mintz 1985) en Puerto Rico, la primera para conocer la historia de las plantaciones y la segunda para realizar una historia de vida de un trabajador de la caña de azúcar. En estos estudios plantea la forma en que la producción de azúcar altera los patrones del trabajo y el impacto que genera la división social del trabajo.

Con respecto a la adquisición de los terrenos para el cultivo de caña, Taussig y Rubbo (2011 [1975]) explican cómo se dio una confrontación directa, incluso a través del despojo legal en complicidad con elites de locales, con campesinos y comunidades negras quienes pasaron de campesinos y cultivadores a asalariados en las haciendas de terratenientes. Estos autores realizaron su trabajo de campo con corteros de caña y trabajadores de la industria pertenecientes a comunidades negras de Puerto Tejada; así como trabajo de archivo para rastrear los cambios desde el fin de la esclavitud hasta la instalación de la proletarización de los campesinos y la migración de las mujeres a la ciudades para trabajar en el servicio doméstico por la escasa tierra para cultivar.

Según Rojas (2017) el establecimiento de la industria a comienzos del siglo XX, después de la instalación del ingenio Manuelita en el Valle del Cauca, se impulsó con la construcción del ferrocarril y el Canal de Panamá. Más tarde desde Asocaña se promovió la instalación de Cenicaña con el propósito de tecnificar el cultivo caña (así como años antes se había promovido la Misión Chardón para el análisis del cultivo, los suelos y las variedades de caña), generando así las condiciones institucionales para la expansión del cultivo y el establecimiento de la industria azucarera. Durante este siglo se establecieron vínculos determinantes entre la economía, el conocimiento de la academia y las políticas favorables del estado para su consolidación.

Para Rojas (2017) lo anterior es una muestra de que se logró un control en la región que incluye, además del uso de los terrenos, estrategias de control frente a la fuerza de trabajo (como la tercerización laboral), usos de fuentes hídricas, características y ubicación de la infraestructura vial, además de significativos efectos sobre la institucionalidad estatal y 
privada en campos como la asistencia agrícola y la educación. Para el autor, el triunfo de la Revolución Cubana fue también un determinante para el crecimiento y modernización de la industria azucarera colombiana.

Con respecto a los trabajadores de la industria Hurtado y Urrea-Giraldo (2004) afirman que el movimiento sindical obrero de la caña, aparece en el norte del departamento del Cauca entre la segunda mitad de la década del 50 y la primera del 60 a través de la Federación de Trabajadores del Valle (Fedetev) asociada a la CTC, en aquella época muy cercana al partido liberal. Para la década del 70 este movimiento sindical azucarero se debilitó y quedó solamente asociado a la fábrica y al ingenio. Según los autores la procedencia de trabajadores migrantes del Pacífico nariñense con bajo capital escolar y cultural fueron características fundamental para que se establecieran como una población dócil a la disciplina laboral. Al tiempo que fueron favorables en la constitución de sindicatos patronales.

Para Urrea Giraldo (2010) en el año 2000 comienza un proceso importante de subcontratación en la industria azucarera una muestra de esto, fueron las CTA que operaban como empresas de intermediación laboral, sin imponer responsabilidades propias de los contratos laborales. Para la primera década de este siglo las agencias temporales de empleo, las CTA y otras modalidades de intermediación laboral respondieron por todo el empleo manufacturero por fuera de la contratación directa.

En cuanto a la precariedad laboral en la industria azucarera Pérez y Álvarez (2009) realizaron un estudio con los recibos de pago de 438 trabajadores de las CTA La Manuela y La Nueva y encontraron que después de todos los descuentos que le hacen a los trabajadores solo reciben el $48 \%$ de su salario. Además los autores tomaron el salario base de los corteros ${ }^{6}$ contratados de manera directa y los subcontratados por medio de CTA para compararlos y concluir que los ingenios se ahorraron en promedio 46 mil millones al mantener a sus trabajadores contratados por medio de las CTA (Pérez y Álvarez 2009, 53). El problema es

\footnotetext{
${ }^{6}$ Pérez y Álvarez (2009) afirman que el salario de los corteros para el año de estudio este estaba alrededor de los 2 SMMLV, es decir unos $\$ 850$ mil pesos. Sin embargo esta cifra se toma antes de los descuentos que hacen las CTA a los trabajadores para su sostenimiento, ni los aportes de seguridad social. Además existen diferencias entre los corteros contratado de manera directa por el ingenio con uno contratado por medio de las CTA. Los directos recibían un ingreso neto de $\$ 937$ mil mientras que los subcontratados recibían será de \$519 mil. Basado en esta diferencia entre los ingresos los autores toman los recibos de pago de 438 trabajadores de las CTA La Manuela y La Nueva y lo multiplicaron por la cantidad de corteros asociados a la industria para calcular la deuda del sector azucarero con estos trabajadores.
} 
que ellos toman una muestra de dos CTA que no resultan representativas de todo el sector para después hacer unos cálculos que pretenden dar cuenta de toda la problemática de tercerización. Los autores utilizan estos cálculos, y otros sobre la problemática ambiental, para ponerle precio a la "deuda social" que el sector tiene con la sociedad civil.

La revisión de literatura muestra que han sido múltiples los estudios sobre la industria azucarera, especialmente, en cuanto al tema de la precarización y la tercerización laboral donde se abordan específicamente las problemáticas asociadas a las CTA (Lasso-Ortega 2015; MME y BID 2012; Urrea Giraldo 2010; Álvarez y Roa, 2009; Aricarpa 2006) y de la RSE (Ronderos 2011; Rojas 2014). No obstante, no se han abordado de manera amplia, las nuevas formas de tercerización presentes en la industria azucarera por medio de las empresas de corte, ni su relación con la RSE como una respuesta institucional a los conflictos obreropatronales de la primera década del 2000. Por tanto, este trabajo tiene como propósito hacer un aporte a la comprensión de la función de la RSE, leída como un nuevo paternalismo burocratizado que los trabajadores tercerizados configuran como un ámbito en disputa, en un contexto de altos niveles de tercerización laboral.

\section{A.3. Metodología}

A partir de los paros de corteros del 2005 y 2008 los ingenios tecnificaron aún más sus instalaciones en cuanto al tema de seguridad. Ahora, tienen registros de "quién viene a la oficina, cuál es el objeto de la visita [...] la huella de la persona, las cédulas de ciudadanía, control exacto de la hora de ingreso y de la hora de salida y qué persona autoriza el ingreso" (Andrés Castro: 21 de julio de 2015). Inclusive hay guardias de seguridad en las puertas de acceso y ya no es tan fácil entrar. Estas empresas se han convertido en enclaves de seguridad que según Welker (2009), son el resultado de una relación entre la aplicación de programas de RSE y la seguridad corporativa como una forma de mantener por fuera de la empresa, tanto a personas de la comunidad como a los trabajadores mismos (en horarios no laborales) por medio guardias de seguridad armados, altas paredes, alambres de púas, etc.

En virtud del acceso restringido a las instalaciones de los ingenios y circulación en los mismos se desestimó la posibilidad de realizar una etnografía y la estrategia metodológica se centró en entrevistas, observaciones específicas y análisis de documentos legales. A fin de establecer contactos con las áreas de Relaciones Industriales y de Gestión Humana de 
diferentes ingenios debí tramitar permisos por medio de Asocaña. Estos permisos fueron otorgados en los ingenios El Centenario y El Dorado ${ }^{7}$ donde se realizaron 24 entrevistas en profundidad y observación participante para la recolección de datos (Ver Tabla $\mathrm{N}^{\circ} 1$ ).

En ese sentido, es fundamental aclarar que El Centenario es uno de los ingenios más grandes, produce etanol, cogenera energía, produce derivados de la caña de azúcar, además ha adquirido varios ingenios dentro y fuera del país y tiene acciones en otros como El Dorado. No obstante, a pesar de las significativas partes accionarias que este ingenio ha adquirido, los trabajadores de las empresas adquiridas no se benefician de las convenciones colectivas o derechos adquiridos de la empresa adquiriente. Además, tienen programas de RSE muy grandes dentro y fuera (por medio de su fundación) del ingenio.

Tabla 1 Ingenio EI Centenario-Cantidad de Trabajadores. Fuente: informes de sostenibilidad anuales

\begin{tabular}{|c|c|c|c|c|c|c|c|c|c|c|c|c|}
\hline & \multicolumn{2}{|c|}{2010} & \multicolumn{2}{|c|}{2011} & \multicolumn{2}{|c|}{2012} & \multicolumn{2}{|c|}{2013} & \multicolumn{2}{|c|}{2014} & \multicolumn{2}{|c|}{2015} \\
\hline & $\begin{array}{l}\text { Número } \\
\text { trabajadores }\end{array}$ & Porcentaje & \begin{tabular}{|l|} 
Número \\
trabajadores
\end{tabular} & Porcentaje & \begin{tabular}{|} 
Número \\
trabajadores
\end{tabular} & Porcentaje & $\begin{array}{l}\text { Número } \\
\text { trabajadores }\end{array}$ & Porcentaje & $\begin{array}{l}\text { Número } \\
\text { trabajadores }\end{array}$ & Porcentaje & \begin{tabular}{|l|} 
Número \\
trabajadore \\
$\mathrm{s}$
\end{tabular} & Porcentaje \\
\hline \begin{tabular}{|l|} 
Personal Operativo \\
\end{tabular} & 1293 & 48,7 & 1333 & 45,8 & 1532 & 50,9 & 1609 & 84,3 & 1606 & 84,7 & 1624 & 85,6 \\
\hline Personal Administrativo & 158 & 6,0 & 167 & 5,7 & 173 & 5,7 & 178 & 9,3 & 185 & 9,8 & 208 & 11,0 \\
\hline \begin{tabular}{|l|} 
Contratistas \\
\end{tabular} & 1008 & 38,0 & 1183 & 40,6 & 1070 & 35,5 & & - & & - & & - \\
\hline Temporales & 136 & 5,1 & 159 & 5,5 & 136 & 4,5 & 121 & 6,3 & 106 & 5,6 & 162 & 8,5 \\
\hline Aprendices Sena & 59 & 2,2 & 69 & 2,4 & 99 & 3,3 & & - & & - & & - \\
\hline Totales & 2654 & 100 & 2911 & 100 & 3010 & 100 & 1908 & 100 & 1897 & 100 & 1994 & 100 \\
\hline
\end{tabular}

Tabla 2 Ingenio El Centenario-Tipo de contratación. Fuente: informes de sostenibilidad anuales

\begin{tabular}{|c|c|c|c|c|c|c|c|c|c|c|c|c|}
\hline Tipo de Empleo & \multicolumn{2}{|c|}{2010} & \multicolumn{2}{|c|}{2011} & \multicolumn{2}{|c|}{2012} & \multicolumn{2}{|c|}{2013} & \multicolumn{2}{|c|}{2014} & \multicolumn{2}{|c|}{2015} \\
\hline \begin{tabular}{|l|} 
Contratación directa \\
\end{tabular} & 1451 & 52,4 & 1500 & 49,8 & 1705 & 54,7 & 1787 & 65,6 & 1791 & 64,8 & 1787 & 64,7 \\
\hline Contratación Temporal & 136 & 4,9 & 159 & 5,3 & 136 & 4,4 & 121 & 4,4 & 106 & 3,8 & 121 & 4,4 \\
\hline Contratistas externos & 1008 & 36,4 & 1183 & 39,3 & 1070 & 34,3 & 637 & 23,4 & 674 & 24,4 & 637 & 23,1 \\
\hline Aprendices Sena & 59 & 2,1 & 69 & 2,3 & 99 & 3,2 & 102 & 3,7 & 107 & 3,9 & 102 & 3,7 \\
\hline Jubilados y planes especiale & 115 & 4,2 & 103 & 3,4 & 109 & 3,5 & 76 & 2,8 & 84 & 3,0 & 76 & 2,8 \\
\hline \begin{tabular}{|l|} 
Totales \\
\end{tabular} & 2769 & 100 & 3014 & 100 & 3119 & 100 & 2723 & 100 & 2762 & 100 & 2723 & 100 \\
\hline
\end{tabular}

Tabla 3 Ingenio El Centenario- Trabajadores discriminados por sexo.

Fuente: informes de sostenibilidad anuales

\begin{tabular}{|c|c|c|c|c|c|c|c|c|c|c|c|c|}
\hline Desglose por Sexo & \multicolumn{2}{|c|}{2010} & \multicolumn{2}{|c|}{2011} & \multicolumn{2}{|c|}{2012} & \multicolumn{2}{|c|}{2013} & \multicolumn{2}{|c|}{2014} & \multicolumn{2}{|c|}{2015} \\
\hline Femenino & 133 & 9,2 & 154 & 9,3 & 145 & 8,5 & 150 & 8,4 & 151 & 8,4 & 171 & 9,5 \\
\hline Masculino & 1318 & 90,8 & 1505 & 90,7 & 1560 & 91,5 & 1637 & 91,6 & 1640 & 91,6 & 1661 & 92,7 \\
\hline Totales & 1451 & 100 & 1659 & 100 & 1705 & 100 & 1787 & 100 & 1791 & 100 & 1832 & 102 \\
\hline
\end{tabular}

Por otra parte, El Dorado es un ingenio pequeño que aún tiene rasgos del pasado paternalista donde tanto los dueños como los trabajadores vivían en sus instalaciones, incluso aún hoy hay personas viviendo ahí. Además permanecen intactas la iglesia, el trapiche donde empezó todo y los primeros molinos de la fábrica. El estudio de ambos casos permite dar

\footnotetext{
${ }^{7}$ Se cambiaron los nombres de ambos ingenios como un compromiso asumido para realizar el trabajo de campo.
} 
cuenta de cambios en las relaciones obrero-patronales propias de la industria azucarera y de estos ingenios.

Tabla 4 Ingenio El Dorado-Cantidad de Trabajadores. Fuente: informes de sostenibilidad anuales

\begin{tabular}{|c|c|c|c|c|c|c|c|c|c|c|c|c|}
\hline & \multicolumn{2}{|c|}{2010} & \multicolumn{2}{|c|}{2011} & \multicolumn{2}{|c|}{2012} & \multicolumn{2}{|c|}{2013} & \multicolumn{2}{|c|}{2014} & \multicolumn{2}{|c|}{2015} \\
\hline & \begin{tabular}{|l|} 
Número \\
trabajadore \\
s
\end{tabular} & Porcentaje & $\begin{array}{l}\text { Número } \\
\text { trabajadore } \\
\text { s }\end{array}$ & Porcentaje & \begin{tabular}{|l|} 
Número \\
trabajadore \\
s
\end{tabular} & Porcentaje & \begin{tabular}{|l|} 
Número \\
trabajadore \\
s
\end{tabular} & Porcentaje & \begin{tabular}{|l|} 
Número \\
trabajadore \\
s
\end{tabular} & Porcentaje & \begin{tabular}{|l|} 
Número \\
trabajadore \\
s
\end{tabular} & Porcentaje \\
\hline Personal Operativo & 506 & 65,6 & 532 & 66,9 & 541 & 67,1 & \begin{tabular}{|l|}
507 \\
\end{tabular} & 66,7 & 488 & 67,7 & 479 & 67,8 \\
\hline Personal Administrativo & 265 & 34,4 & 263 & 33,1 & 265 & 32,9 & 253 & 33,3 & 233 & 32,3 & 227 & 32,2 \\
\hline Total & 771 & 100 & 795 & 100 & 806 & 100 & 760 & 100 & 721 & 100 & 706 & 100 \\
\hline
\end{tabular}

Tabla 5 Ingenio El Dorado- Sexo trabajadores. Fuente: informes de sostenibilidad anuales

\begin{tabular}{|c|c|c|c|c|c|c|c|c|c|c|c|c|}
\hline Desglose por Sexo & \multicolumn{2}{|c|}{2010} & \multicolumn{2}{|c|}{2011} & \multicolumn{2}{|c|}{2012} & \multicolumn{2}{|c|}{2013} & \multicolumn{2}{|c|}{2014} & \multicolumn{2}{|c|}{2015} \\
\hline Masculino & 699 & 91,9 & 727 & 91,4 & 740 & 91,8 & 699 & 92,0 & 663 & 92,0 & 648 & 91,8 \\
\hline Femenino & 62 & 8,1 & 68 & 8,6 & 66 & 8,2 & 61 & 8,0 & 58 & 8,0 & 58 & 8,2 \\
\hline Totales & 761 & 100 & 795 & 100 & 806 & 100 & 760 & 100 & 721 & 100 & 706 & 100 \\
\hline
\end{tabular}

En El Centenario las entrevistas fueron realizadas a empleados de las oficinas de Relaciones Industriales: bienestar social, fundación y relación con la comunidad. Así como entrevistas a varios trabajadores directos escogidos por la jefe de bienestar social, fueron realizadas en las oficinas del ingenio y por un tiempo limitado pues estos trabajadores estaban en horario laboral. Todas las entrevistas de las personas de este ingenio fueron realizadas en sus instalaciones a excepción de la del presidente del sindicato, que fue en la sede del mismo. Los datos recolectados en estas entrevistas son parte fundamental del análisis sobre los paros del 2005 y 2008 y los programas de RSE.

En el ingenio El Dorado se entrevistó al gerente y a una trabajadora del área de Gestión Humana. Desde dicha área, me contactaron con el tesorero del sindicato y con un contratista que vivía en el ingenio. Estas entrevistas fueron realizadas en los terrenos del ingenio. El resto fueron realizadas a trabajadores retirados de este ingenio o por fuera del horario laboral y de los terrenos de la empresa. Estos datos fueron el insumo fundamental para el desarrollo del primer capítulo y la caracterización de la vida dentro del ingenio, así como las implicaciones de ambos paros.

Además se realizaron varias entrevistas a otras personas que hacen parte del sector pero que no están ni en uno ni en otro ingenio como se muestra en el siguiente cuadro. 
Tabla 6 Entrevistas a profundidad

\begin{tabular}{|c|c|c|c|c|}
\hline & $\begin{array}{l}\text { Fecha y lugar de } \\
\text { la entrevista }\end{array}$ & $\begin{array}{l}\text { Cambio de } \\
\text { nombre }\end{array}$ & Ingenio & Cargo \\
\hline E1 & $\begin{array}{l}4 \text { de agosto de } \\
2015 \\
\text { Sede del } \\
\text { sindicato }\end{array}$ & José Aragón & Sintrazúcar & $\begin{array}{l}\text { Presidente de Sintrazúcar, } \\
\text { sindicato asociado a la CGT. } \\
\text { Además hace parte de } \\
\text { múltiples organismos } \\
\text { sindicales a nivel regional y } \\
\text { nacional }\end{array}$ \\
\hline E2 & $\begin{array}{l}8 \text { de julio de } \\
2015 \\
\text { Oficina del } \\
\text { ingenio }\end{array}$ & $\begin{array}{l}\text { Alejandro } \\
\text { Rengifo }\end{array}$ & Dorado & $\begin{array}{l}\text { Gerente de El Dorado desde } \\
\text { el año } 2007\end{array}$ \\
\hline E3 & $\begin{array}{l}24 \text { de julio de } \\
2015 \\
\text { En su Casa }\end{array}$ & Oscar Coronel & El Dorado & $\begin{array}{l}\text { Trabajó en la oficina de } \\
\text { contaduría y vivió muchos } \\
\text { años en en el ingenio. En esa } \\
\text { casa murió su esposa y se } \\
\text { volvió a casar con la hija de } \\
\text { otro empleado del ingenio. }\end{array}$ \\
\hline E4 & $\begin{array}{l}16 \text { de octubre de } \\
2015 \\
\text { Oficina del } \\
\text { ingenio }\end{array}$ & Mario Riveros & El Centenario & Mecánico de empaque \\
\hline E5 & $\begin{array}{l}10 \text { de julio de } \\
2015 \\
\text { Ingenio }\end{array}$ & Henry Parra & El Dorado & $\begin{array}{l}\text { Jubilado y ahora contratista } \\
\text { del ingenio }\end{array}$ \\
\hline E6 & $\begin{array}{l}16 \text { de octubre de } \\
2015 \\
\text { Oficina del } \\
\text { ingenio }\end{array}$ & $\begin{array}{l}\text { Humberto } \\
\text { Sánchez }\end{array}$ & El Centenario & $\begin{array}{l}\text { Supervisor de aplicación de } \\
\text { compost. Empezó su carrera } \\
\text { laboral como cortero de } \\
\text { caña. }\end{array}$ \\
\hline E7 & $\begin{array}{l}30 \text { de junio de } \\
2015 \\
\text { Ingenio }\end{array}$ & $\begin{array}{l}\text { Carolina } \\
\text { Trujillo }\end{array}$ & El Dorado & $\begin{array}{l}\text { Trabajadora social del } \\
\text { ingenio }\end{array}$ \\
\hline E8 & $\begin{array}{l}28 \text { de diciembre } \\
\text { de } 2016 \\
\text { En su casa }\end{array}$ & $\begin{array}{l}\text { Ernesto } \\
\text { Lopera }\end{array}$ & $\begin{array}{l}\text { Servicios de } \\
\text { Cosecha } \\
\text { Dorado }\end{array}$ & $\begin{array}{l}\text { Supervisor de corte en } \\
\text { Servicios de cosecha } \\
\text { Dorado. Inició su carrera } \\
\text { laboral como cortero. }\end{array}$ \\
\hline
\end{tabular}




\begin{tabular}{|c|c|c|c|c|}
\hline E9 & $\begin{array}{l}16 \text { de octubre de } \\
2015 \\
\text { Oficina del } \\
\text { ingenio }\end{array}$ & Eder Arzuaga & El Centenario & Cortero \\
\hline E10 & $\begin{array}{l}16 \text { de octubre de } \\
2015 \\
\text { Oficina del } \\
\text { ingenio }\end{array}$ & $\begin{array}{l}\text { Hernando } \\
\text { Galeano }\end{array}$ & El Centenario & $\begin{array}{l}\text { Monitor de corte. Inició su } \\
\text { carrera laboral como cortero. }\end{array}$ \\
\hline E11 & $\begin{array}{l}16 \text { de octubre de } \\
2015 \\
\text { Oficina del } \\
\text { ingenio }\end{array}$ & Héctor Vaca & El Centenario & $\begin{array}{l}\text { Monitor de corte. Inició su } \\
\text { carrera laboral como cortero. }\end{array}$ \\
\hline E12 & $\begin{array}{l}8 \text { de julio de } \\
2015 \\
\text { Sede del } \\
\text { sindicato }\end{array}$ & Jaime Salazar & Sintradorado & Tesorero de Sintradorado \\
\hline E13 & $\begin{array}{l}16 \text { de octubre de } \\
2015 \\
\text { Oficina del } \\
\text { ingenio }\end{array}$ & $\begin{array}{l}\text { Esteban } \\
\text { Salazar }\end{array}$ & El Centenario & $\begin{array}{l}\text { Oficios varios de ingeniería. } \\
\text { Hijo de un cortero. }\end{array}$ \\
\hline E14 & $\begin{array}{l}11 \text { de agosto de } \\
2015 \\
\text { Oficina del } \\
\text { ingenio }\end{array}$ & David Campo & El Centenario & $\begin{array}{l}\text { Director de la Fundación del } \\
\text { Ingenio }\end{array}$ \\
\hline E15 & $\begin{array}{l}4 \text { de agosto de } \\
2015 \\
\text { Oficina del } \\
\text { ingenio }\end{array}$ & León Aguirre & El Centenario & $\begin{array}{l}\text { Líder del paro de corteros } \\
\text { del } 2008 \text {. Actualmente } \\
\text { trabaja como contratista del } \\
\text { ingenio en oficios varios y } \\
\text { hace parte de la escuela de } \\
\text { liderazgo. }\end{array}$ \\
\hline E16 & $\begin{array}{l}16 \text { de octubre de } \\
2015 \\
\text { Oficina del } \\
\text { ingenio }\end{array}$ & $\begin{array}{l}\text { Francisco } \\
\text { Castro }\end{array}$ & El Centenario & Operador de tractomula \\
\hline E17 & $\begin{array}{l}16 \text { de octubre de } \\
2015\end{array}$ & Camilo Uribe & El Centenario & $\begin{array}{l}\text { Mecánico de } 1^{\mathrm{a}} \\
\text { mantenimiento de } \\
\text { centrífugas }\end{array}$ \\
\hline
\end{tabular}




\begin{tabular}{|c|c|c|c|c|}
\hline & $\begin{array}{l}\text { Oficina del } \\
\text { ingenio }\end{array}$ & & & \\
\hline E18 & $\begin{array}{l}4 \text { de agosto de } \\
2015 \\
\text { Oficina del } \\
\text { ingenio }\end{array}$ & $\begin{array}{l}\text { Miriam } \\
\text { Salazar }\end{array}$ & El Centenario & $\begin{array}{l}\text { Jefe del departamento de } \\
\text { bienestar social }\end{array}$ \\
\hline E19 & $\begin{array}{l}7 \text { de julio de } \\
2015 \\
\text { En su casa }\end{array}$ & $\begin{array}{l}\text { Padre Juan } \\
\text { Pardo }\end{array}$ & $\begin{array}{l}\text { Ingenio } \\
\text { Verde }\end{array}$ & $\begin{array}{l}\text { Fue el párroco del ingenio } \\
\text { Verde y ayudó a crear el } \\
\text { Centro de Formación } \\
\text { Integral }\end{array}$ \\
\hline E20 & $\begin{array}{l}6 \text { de agosto de } \\
2015 \\
\text { Ingenio }\end{array}$ & Stella Galvis & El Centenario & $\begin{array}{l}\text { Jefe de relacionamiento con } \\
\text { la comunidad }\end{array}$ \\
\hline E21 & $\begin{array}{l}21 \text { de julio de } \\
2015 \\
\text { Sede del } \\
\text { sindicato }\end{array}$ & Andrés Castro & Sintracultivos & Presidente de Sintracultivos \\
\hline E22 & $\begin{array}{l}22 \text { de julio de } \\
2015 \\
\text { En su casa }\end{array}$ & Julián Lorza & El Dorado & $\begin{array}{l}\text { Contador del ingenio entre } \\
\text { 1960-1980 y vivió allá } \\
\text { durante ese tiempo. }\end{array}$ \\
\hline E23 & $\begin{array}{l}27 \text { de julio de } \\
2017\end{array}$ & $\begin{array}{l}\text { Adolfo } \\
\text { Madrid }\end{array}$ & & $\begin{array}{l}\text { Abogado laboralista del } \\
\text { gremio }\end{array}$ \\
\hline E24 & $\begin{array}{l}15 \text { de agosto de } \\
2017 \\
\text { Universidad }\end{array}$ & $\begin{array}{l}\text { Iván Daniel } \\
\text { Jaramillo }\end{array}$ & $\begin{array}{l}\text { Universidad } \\
\text { del Rosario }\end{array}$ & $\begin{array}{l}\text { Abogado laboralista, } \\
\text { profesor e investigador }\end{array}$ \\
\hline
\end{tabular}


Por último la sistematización de los datos de realizó por medio de un índice comentado que permitió la codificación de las entrevistas basados en categorías emergentes y teóricas (Schreier 2014). Las entrevistas se dividieron en cuatro grupos diferentes que permitían buscar patrones de homogeneidad/ heterogeneidad y de conexiones explicativas para hacer conclusiones a partir de los datos recogidos. Estos grupos eran (1) administrativos, profesionales y supervisores / trabajadores / sindicatos; (2) los entrevistados son, fueron, o sus padres eran corteros / no son; (3) retirados / activos; (4) El Dorado / El Centenario.

\section{B.1. Paternalismo}

B.1.1. Paternalismo como eje de análisis de la relación obrero-patronal y sus formas de contratación (Valero 2013; González 2016; Urrea Giraldo 2010).

B.1.2. Condiciones de vida y de trabajo durante la etapa de paternalismo en los ingenios (concepto emergente).

B.2. Neoliberalismo proyecto político (Brenner y Theodore 2002; Misas 2002)

B.2.1. Contexto nacional de neoliberalismo (González 2016; Vejar 2013; Urrea Giraldo 2010).

B.2.2. Relación estado-industria azucarera (concepto emergente).

B.2.3. Legislación que permite la tercerización laboral (Aricarpa 2006; Ronderos 2011; Observatorio Laboral UR; Observatorio del Mercado del Trabajo 2007).

C.1. Narrativas de otredad e ingenios como agentes civilizatorios

C.1.1. Corteros y el oficio de cortar de caña (concepto emergente) / (agente civilizatorio Fernando Urrea Giraldo 2007).

C.1.2. Narrativas de otredad sobre los corteros basadas en imaginarios de analfabetismo, manejo del dinero, vicios y sus familias (concepto emergente).

C.2. De relación laboral a relación comercial

C.2.1. Las distintas formas de contratación en el proceso de tercerización laboral y los paros del 2005 y 2008 (concepto emergente).

C.2.2. El establecimiento de la relación comercial: Servicios de Cosecha Dorado y Centenario Corte (concepto emergente).

C.2.3. Pacto Global como respuesta a la crisis corteros-ingenios (concepto emergente).

C.3. Asociación colectiva o representación (concepto emergente).

D.1. Paternalismo o RSE: continuidades, rupturas, grupos de interés y productividad

D.1.1. Del paternalismo tradicional a la burocratizada RSE: las rupturas y continuidades (Valero 2013; Dolan \& Rajak 2016; Cross 2016; Banerjee 2008)

D.1.2. Los efectos adversos que dejan las distintas formas de relación entre el ingenio y sus grupos de interés en búsqueda de la productividad (Cross 2016; Banerjee 2008; Benson et al. 2010; Basualdo \& Morales 2014;

Benson y Kirsch 2010).

D.2. La responsabilidad social empresarial una arena en disputa (concepto emergente). 


\section{B. Capítulo 1. Paternalismo y neoliberalismo: dos ejes para el análisis de las condiciones de vida y trabajo en los ingenios}

El objetivo de este capítulo es exponer cómo el paternalismo y el neoliberalismo (entendidos como formas de relación obrero-patronal y proyecto político-económico) inciden en las condiciones de vida y de trabajo de los trabajadores de la industria azucarera. Para entender el contexto en que se desarrolla el sistema paternalista empresarial se realiza un recuento de las condiciones políticas y económicas del país hacia la segunda mitad del siglo XX. Después, se describen las condiciones de vida y de trabajo de aquellas personas que vivían en los ingenios, en ocasiones junto a sus familias, porque por su oficio y la organización de la producción debían estar disponibles en todo momento. En este contexto resulta difícil separar unas de otras.

En el segundo subcapítulo se enuncia qué se entiende por neoliberalismo en este trabajo y sus efectos en las relaciones laborales y las condiciones de vida y de trabajo. Así como ciertas características de las empresas neoliberales. Posteriormente, se presenta la forma en que la (des)regulación laboral neoliberal genera relaciones contradictorias con la industria azucarera. Pues en ocasiones beneficia a la industria a través de incentivos proteccionistas y la promoción de la tercerización laboral, pero en otras ocasiones la castiga bajo la premisa del libre comercio y el fomento de una competencia justa.

Por último, el texto se detiene en el contexto normativo que ha permito al gremio azucarero tercerizar a los corteros en el marco de la ley. En este proceso se superponen varias formas de subcontratación. La exposición de este capítulo se articula alrededor de lo sucedido en el ingenio El Dorado, no obstante se realizan algunas alusiones a El Centenario con el fin de hacer énfasis o marcar alguna diferencia entre ellos.

El Dorado se ubica en el centro del Valle del Cauca. Fue fundado a principios de la década del 40 por Marcelo $\mathrm{Cano}^{8}$ quien posteriormente invitó a su hermana Margarita y otros accionistas minoritarios a hacer parte de la empresa, pues ella tenía una mayor cantidad de tierras sembradas en caña. Durante los primeros años de funcionamiento el mayor accionista y gerente era don Marcelo. Él vivía en el ingenio junto a su esposa y sus cinco hijos. Hacia

\footnotetext{
${ }^{8}$ Los nombres de los fundadores de los ingenios fueron cambiados y se utilizan alias.
} 
la década del 60 tenían alrededor de 1200 empleados, la mayoría trabajaba en el campo en labores de siembra, corte, alce y transporte. Para la misma época de instalación de la industria azucarera otro hermano fundó el ingenio Verde (Julián Lorza ${ }^{9}$, contador del ingenio Dorado entre 1960-1989: 22 de julio de 2015).

El Centenario está ubicado en el sur del Valle del Cauca, a finales de la década del 30 la pareja de esposos Juliana María y Trasíbulo lo fundaron, aunque en principio comenzó como un trapiche de caña, después fue creciendo hasta llegar a ser una de las compañías agroindustriales más grandes del sector. Con el crecimiento del ingenio, la mano de obra disponible en sus alrededores resultaba insuficiente, lo cual impulsó la búsqueda hacia otras regiones, especialmente al Pacífico Nariñense.

Así, muchos trabajadores migraron a trabajar al ingenio, algunos llegaron sin sus familias a vivir en unos campamentos cerca al Centenario. Miriam Salazar, directora del área de bienestar social, explica que este fue uno de los motivos por los cuales se buscó traer a sus familias y brindarles viviendas dignas. Esto puede interpretarse tanto como un mecanismo para mejorar su calidad de vida, como una manera de disciplinar a estos nuevos asalariados que presentaban altos niveles de ausentismo y alcoholismo. Hoy por hoy muchas de las personas que trabajan allí son hijos y familiares de los primeros trabajadores, empleados y fundadores del ingenio.

\section{B.1. Paternalismo como eje de análisis de la relación obrero-patronal y sus formas de contratación}

El objetivo de este subcapítulo es tomar como eje de análisis el paternalismo, para entender la relación entre el estado, la iglesia, la empresa y las implicaciones que esta relación tenía en las condiciones de vida y del trabajo al interior de los ingenios. Específicamente, se nombran algunas hitos de la coyuntura nacional que ayudan a caracterizar el contexto en que se desarrollan dichas relaciones laborales. En la época en que los trabajadores de los ingenios vivían en las empresas junto a los fundadores, padres y monjas de la iglesia católica y las acciones en pro del bienestar social de los trabajadores estaban en manos de estos representantes de la iglesia católica. En ocasiones, la empresa también cubría algunas

\footnotetext{
${ }^{9}$ Los nombres de los entrevistados fueron cambiados y se utilizan alias para proteger su identidad como parte del acuerdo para realizar y utilizar las entrevistas.
} 
funciones como brindar salud, educación, vivienda y servicios públicos. Hacia la década del 80 tras la muerte del fundador del ingenio y en el marco del establecimiento de un proyecto político-económico neoliberal se observan cambios en las condiciones de vida y de trabajo de quienes trabajaban ahí.

\section{B.1.1. El paternalismo y su contexto político nacional}

Según Valero (2013), el paternalismo puede ser entendido como un instrumento de control que se inspiró en valores opuestos a los principios de la modernidad como la libertad, la autonomía y la equidad. El control que se ejerció desde la autoridad tradicional en la cual se enmarca el paternalismo no fue en "virtud de la capacidad de coacción física", en cambio este control se hizo a través de un acuerdo implícito de "compromisos recíprocos" entre quien ejerce el poder y quienes obedecen. Quien ejerce poder aporta protección y deferencia a cambio de lealtad y obediencia.

Esto implica "que las formas paternalistas de relaciones obrero-patronales, han sido hasta cierto punto, una necesidad y una solución inevitable dadas las características de la fuerza laboral vinculada a la empresa y al trabajo industrial en las circunstancias de cada momento" (Valero 2013, 24). Dicha forma de relación no genera responsabilidades para quienes ostentan el poder, pero cumplen con la función de preservar el orden social, al disimular las duras imposiciones a cambio de lealtad. Según Valero (2013), el accionar personalizado y dadivoso de los empresarios puede ser interpretado como bondad patronal y por tanto resulta fundamental analizar las expresiones estacionales que genera este tipo de relaciones, marcadas por el paternalismo dentro de las cuales se evidencia un control total de la vida de los trabajadores que desborda la concepción clásica de compra de la fuerza del trabajo. En ese sentido, la manifestación del poder puede ser visto como mediador en las relaciones sociales.

Desde las formas paternalistas de relación obrero-patronales, los empresarios brindaban servicios, que no eran impuestos por el mercado o el estado, donde se combinaban elementos ideológicos y pragmáticos que estaban alineados con sus objetivos, como el aumento de la productividad. Desde el patronato se trataban todo tipo de temas asociados a los trabajadores como: enfermedades, accidentes, viviendas, educación, ocio sano, pensión por invalidez, viudez, huerfanidad "en ellos el patrón se convertía en organizador de la 
seguridad del obrero, a quien se veía como incapaz de previsión y ahorro" (Valero 2013, 41). En ese escenario las prácticas patronales responden a "una calculada obsequiosidad que corresponde a propósitos de control, legitimidad de la autoridad y manejo de la fuerza de trabajo" (Valero 2013, 41). La iglesia católica jugó un papel fundamental en este contexto donde se fue convirtiendo en un "fuerte elemento integrador de las prácticas paternalistas en las primeras décadas del desarrollo industrial colombiano" (Valero 2013, 382).

La era paternalista clásica en los ingenios se sitúa temporalmente en el Frente Nacional, que según González (2016), surgió como una alternancia en el poder de los partidos liberal y conservador por cuatro períodos presidenciales consecutivos para controlar la violencia bipartidista desbordada que se vivía principalmente en el campo colombiano a raíz del asesinato de Jorge Eliecer Gaitán en 1948. El Frente Nacional se instauró en 1958 en un contexto internacional marcado por la Guerra Fría, la división del comunismo internacional, la Revolución Cubana, los cambios internos de la iglesia católica latinoamericana y su radicalización, los cuales rompen con la previa concepción de país.

Los primeros años del Frente Nacional estuvieron marcados por una supuesta paz y tranquilidad en las ciudades que permitió la reconciliación entre la iglesia y el partido liberal. No obstante en el campo la situación era diferente. Durante las dos primeras administraciones la violencia generó grandes migraciones de los campesinos a las ciudades que generaban una demanda en la ampliación de la cobertura educativa y en general de servicios. Sin embargo, el estado se mostró incapaz de proporcionar servicios públicos, empleo a la creciente población urbana y en general no fue capaz de suplir las nuevas necesidades de la ciudadanía (González 2016).

Más adelante, durante el gobierno de Lleras Restrepo continuó la política de la sustitución de importaciones. Por un lado, se impulsó la construcción de vías para proveer el mercado interno del centro del país. Por el otro, se dio una intervención activa para proteger e incentivar el sector industrial mediante la adjudicación de subsidios a la producción interna y altos aranceles a las importaciones (Urrea-Giraldo 2010). Lo cual según Valero (2013) en Colombia benefició a los empresarios con altas sumas de dinero provenientes de políticas públicas favorables a sus intereses. Esto ayudó a la instalación del mayor centro de concentración de crecimiento económico entre Medellín, Cali y Bogotá donde "los altos 
aranceles a las importaciones industriales funcionaron como un subsidio para las regiones comprendidas en el triángulo y como un impuesto para el resto" (González 2016, 357).

Después de los cuatro períodos presidenciales que duró el Frente Nacional comenzó la administración de López Michelsen en la cual se realizó una reforma laboral que permitió el pago del salario integral, es decir, la empresa paga una cantidad de dinero por el trabajo sin diferenciar el salario de las prestaciones sociales. En el mismo periodo aparecieron las primeras empresas de empleo temporal que servían para la subcontratación en la industria manufacturera. Esta administración dio vía libre a las empresas temporales, a la subcontratación y a los contratos a término fijo que pasaron del sector privado al público (Urrea-Giraldo 2010).

Todo esto tuvo implicaciones a mediano y largo plazo en el sector azucarero. Como veremos a continuación los beneficios que el estado brindó a los empresarios por medio de políticas favorables a sus intereses se evidenciaron en la condiciones de vida y de trabajo de quienes vivían en los ingenios. No obstante con las reformas legales bajo el paradigma neoliberal de precarización laboral, apoyadas en estas reformas anteriores, se afectaron de manera negativa las condiciones de trabajo de los corteros de caña.

\section{B.1.2. Condiciones de vida y de trabajo durante la etapa de paternalismo en los ingenios} La época de consolidación de la agroindustria, y especialmente en los ingenios analizados, se caracterizó por la presencia prácticas paternalistas en las relaciones obrero-patronales las cuales influían de manera directa en la vida de las personas que trabajaban y vivían en las empresas junto a sus familias y a los dueños. Se crearon pequeños pueblos que no tenían alcaldía pero sí tenían un comisariato [tienda], una carnicería, una peluquería, un teatro, una enfermería, unas canchas de tenis o fútbol, e incluso una escuela. Al interior del ingenio estaba "su vínculo familiar y su vínculo comercial, de aquí nadie salía. Esto era como un municipio pequeño dentro de estas instalaciones" (Miriam Salazar, jefe del departamento de bienestar social: 4 de agosto de 2017).

Muchos trabajadores y empleados, e incluso el dueño del ingenio, vivían en los terrenos de El Dorado hasta bien entrada la década de los noventa. El pueblo tenía más o menos 50 casas con acueducto, red de energía y telefónica. Algunos corteros vivían en campamentos al interior o cerca de los terrenos del ingenio "ahí cerca de la oficina, no 
quedaban muy lejos, había otro que estaba a cierta distancia" (Oscar Coronel, trabajó en la oficina de contaduría: 24 de julio de 2015), particularmente, los solteros o quienes tenían a sus familias lejos. Pero hacia 2015 muchas de las antiguas casas pasaron a cumplir otras funciones, otras se adaptaron como apartamentos o habitaciones con baño individual donde quienes viven ahí comparten la cocina y áreas comunes (Alejandro Rengifo, gerente de El Dorado desde el 2007: 8 de julio de 2015).

Al pie de la montaña al fondo del ingenio, hay un lugar donde vivía el fundador y su familia al que le llaman La Hacienda. Más abajo y por fuera del perímetro de La Hacienda, está el pueblito y la iglesia donde vivían, y aún hoy viven, trabajadores y empleados como el contador, el administrador, el director de campo, el químico, etc. En el pueblo vivía un médico que iba por días, hasta que el dueño del ingenio le dijo "se me queda aquí, le doy casa y les doy otras cuestiones y ya estaba todo el tiempo. Lo mismo que los profesores tenían casa, y las monjas vicentinas tenían su convento al lado de la capilla" (Julián Lorza: 22 de julio de 2015).

En El Dorado, según la narración de los entrevistados, existían dos barrios o espacios diferentes en el perímetro del ingenio, uno era el pueblo a las afueras de La Hacienda y el otro era el campamento a donde en principio llegaron a vivir los corteros que migraron solteros. En el pueblito de El Dorado había “capilla, tenía dos escuelas: una para mujeres y otra para hombres. La de mujeres, manejada por las monjas vicentinas y la de hombres, manejada por civiles. La escuela de varones por civiles" (Julián Lorza: 22 de julio 2015) o hermanos de La Salle para hombres (Oscar Coronel: 24 de julio de 2015) ${ }^{10}$.

Los relatos de los entrevistados además dejan ver que los hijos de los administrativos y empleados quienes vivían en el pueblito no asistían a la escuela que quedaba dentro del ingenio. De hecho, para los niños y niñas que vivían en el pueblito había transporte cuatro veces al día en la mañana, al medio día y en la tarde para que pudieran ir a estudiar a Buga. "De hecho, los llevaban al ingenio a almorzar y los devolvían en la tarde para continuar en la segunda jornada y al terminar eran llevados de vuelta al ingenio" (Julián Lorza: 22 de julio 2015).

\footnotetext{
${ }^{10}$ Se conservan las referencias originales de los entrevistados, con sus inconsistencias, frente a los datos de los encargados de la escuela para los hombres.
} 
Además del acueducto contaban con energía eléctrica y líneas telefónicas para comunicarse entre ellos y con el dueño. Pero, principalmente, era para que don Marcelo, “desde su casa pudiera llamar a la oficina y al chofer. Después se tiró la red desde aquí hasta allá y usábamos radioteléfonos donde uno llamaba a la Defensa Civil para que lo comunicaran con quien uno quisiera" (Julián Lorza: 22 de julio de 2015). En esa época existía una tienda llamada comisariato que era administrada por el hijo del dueño del ingenio.

El comisariato cumplía varias funciones como: vender mercado a crédito, que se descontaba del siguiente sueldo; como un espacio para el ahorro de los trabajadores que decidían entregar una porción semanal de su sueldo "uno decía sáqueme de mi pago tal suma y póngalo en el comisariato, suma que podía pedir en cualquier momento"; además, a través del comisariato se realizaban diferentes encargos como electrodomésticos, que los trabajadores podían pagar a través de los ahorros programados o descuentos en cuotas del sueldo. La junta directiva del comisariato incluía algunos trabajados y su contabilidad se hacía por separado (Julián Lorza: 22 de julio de 2015).

Al principio, cuenta Henry Parra, topógrafo jubilado y hoy contratista de El Dorado, había un alambique ${ }^{11}$ en el ingenio, que dejó de funcionar de manera temprana, porque a don Marcelo "como era tan católico, no le gustaba el trago y menos le iba a gustar tener un montón de borrachos por ahí. En el ingenio sí habían casinos, donde uno almorzaba y se podía jugar ajedrez, parqués y billar" (Julián Lorza: 22 de julio de 2015). La distinción de jerarquías entre trabajadores y empleados no se marcaba solo por los lugares de residencia (pueblocampamentos), sino también por el casino que frecuentaban.

Este mundo siempre ha sido así, uno más elitista que otro. Uno del pobre, del cortero de caña, [que] no iba a entrar al casino de los empleados altos, él tenía que ir a su propio casino. Pero si se cachaqueaba, se arreglaba, se bañaba sí podía entrar, porque no se cobraban acciones, pero por costumbre no se metían ahí. Uno era para los administrativos y otro para los de la fábrica y los de campo. Era más parrandero y más fácil que los administrativos fueran al de los trabajadores, porque se gozaba más y se charlaba más y se reía más, porque acá era más cachaco (Julián Lorza: 22 de julio de 2015).

\footnotetext{
${ }^{11}$ Lugar donde se destilaba aguardiente
} 
Al personal que trabajaba en el campo lo recogían cerca de sus casas y lo llevaban hasta sus lugares de trabajo en unos aparatos que se llamaban calambucos. "Calambucos que era como decir usted a un bus quitarle el motor y pegárselo al motor atrás, ese coco pegárselo a un tractor atrás eso era lo que se llamaban Calambucos, esos eran los medios de transporte". O sea, es el "coco que vez de un bus, le quitas el motor y queda la parte de los puestos digámoslo así" (Henry Parra: 10 de julio de 2015).

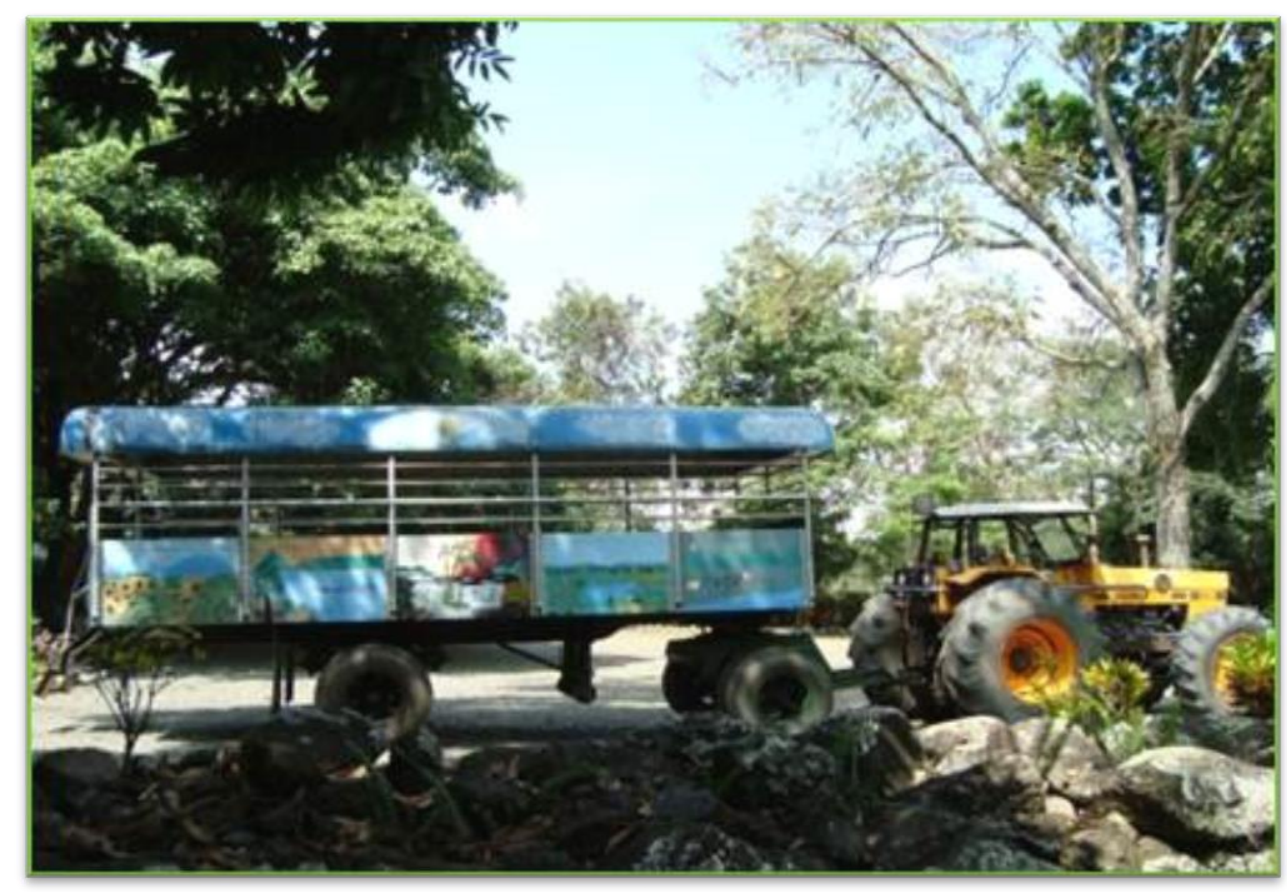

Ilustración 2 Foto de un Calambuco tomada de Boliviatours (s/f)

En cuanto al trabajo temprano con los sindicatos de El Dorado "don Marcelo era un hombre muy cívico y el sindicato era de base ${ }^{12}$, él mismo lo manejaba. Entonces, él se iba a la fábrica y se ponía su casco y saludaba a todos los trabajadores por su nombre" (Julián Lorza: 22 de julio de 2015). El sindicato hacía pliegos, pero nunca paros. Ellos pedían mejores salarios, por ejemplo a los corteros "no se le pagaba salario, si no por tonelada de caña cortada o alzada se les pagaba. Y ellos pedían que le subiera el pago y se arreglaba el problema" (Julián Lorza: 22 de julio de 2015).

\footnotetext{
${ }^{12}$ Es decir, que don Marcelo era quien negociaba directamente con los trabajadores
} 
En esta época el papel de los padres era fundamental para controlar las peticiones que hacían los trabajadores a través de los sindicatos. Ellos quienes también vivían en el ingenio, se aseguraban de que "los trabajadores no se desmidieran pidiendo demasiado, porque nacieron los sindicatos y los sindicatos hacían huelgas, entonces siempre le decían que no acabaran con quien les daba la comida, que bajase porque estaba pidiendo mucho" (Julián Lorza: 22 de julio 2015).

Asimismo, la empresa construyó casas en Buga en diferentes barrios para vendérselas a bajos precios. Las viviendas en el barrio El silencio eran para los obreros, a un precio aproximado de 12 mil pesos, mientras que las casas de la carrera 12 y la carrera 9 eran para los administrativos quienes las adquirieron por 300 mil pesos aproximadamente. Las casas tenían precios bajos, porque el costo del lote fue asumido por el ingenio con el fin de “adjudicar[las] a aquellos trabajadores que tenían más necesidades. Y quedaban debiendo unas platas pequeñas que no pagaban del jornal, si no de la prima y de las cesantías" (Julián Lorza: 22 de julio 2015).

Este modelo de relación obrero-patronal incluía la organización de fiestas patronales por parte del ingenio. "Organizábamos carreras de caballos, de bicicletas, juegos artificiales, riñas de gallos [...] hasta una vez le hice un corralito, digamos un redondel para torear muy chiquito y nos quedó lo más de bueno y él [don Marcelo] nos prestó el ganado" (Oscar Coronel: 24 de julio de 2014). En El Centenario la relación personal y las prácticas dadivosas entre el patrón y los trabajadores era similar.

[En esa época] era la tía del dueño la que venía a preguntarle a usted señora qué le duele, mi mamá se enfermó, se murió, tal cosa, entonces el gerente o director, en ese momento, recibía a la gente de puertas abiertas y mi mamá le pasa eso tenga esta boletica y vaya allá y pide la droga, tenga esta boletica vaya allá que le van a prestar dos pesos, era así. Era muy altruista esa parte social en ese momento [... y] se trabajaba con las monjas, porque aquí se asentó una comunidad de monjas que también fue cuando se decidió fundar el colegio [...] era un trabajo entre monja, padre y tía o mamá de, en ese momento, el dueño que estaba en esos inicios. Era muy altruista (Miriam Salazar: 4 de agosto de 2015).

Esto es un muestra de la relación obrero-patronal estaba marcada por el dueño de la empresa y los representantes de la iglesia que estaban presentes en todos los ámbitos de la 
vida de los trabajadores; desde la vivienda, la educación hasta el tiempo de ocio. Esto muestra el control total de la vida de los trabajadores que exponía Valero (2013).

\section{B.2. Neoliberalismo como proyecto político y económico: nuevos cambios en las formas de relación obrero-patronales}

Hablar de neoliberalismo en Colombia aún genera amplios debates. Por tal razón se retoma la definición de neoliberalismo como un proyecto político y económico, propuesto por Brenner y Theodore (2002), que avanza sobre numerosos derechos adquiridos durante los treinta años célebres del fordismo en el atlántico norte. Y se destaca que Colombia no presenta el mismo punto de partida, ya que la regulación del trabajo asalariado y el apoyo de las empresas estatales al desarrollo urbano e industrial no se asemejan a los casos a partir de los cuales se desarrolló este concepto.

No obstante, la campaña y el gobierno de Gaviria en los 90 contó con el claro apoyo de los principales conglomerados económicos para implementar una serie de reformas características de lo que se denomina neoliberalismo como un proyecto político y económico, tales como, la apertura económica, las reformas del estado, la flexibilización laboral y las privatizaciones, ciertos aspectos y reformas fueron una continuación a políticas del gobierno de Virgilio Barco (Misas 2002). De todas formas, el giro observado en la década del noventa se solapa con el desarrollo de una nueva constitución política que combina elementos del neoliberalismo con intentos de democratización y ampliación de los derechos económicos y sociales en el país.

En el caso de los ingenios, la relación estado-empresarios combina el apoyo en términos de normativas laborales y un mantenimiento de ciertas protecciones frente a la apertura comercial con la penalización de la cartelización y a la tercerización laboral. La transformación de dádivas empresariales en derechos laborales, es seguida por una rápida retracción bajo distintos modelos de tercerización avalados por las normativas de flexibilización laboral, al tiempo que se desplazan los conflictos y se fragmenta al conjunto de los trabajadores con ayuda de la RSE.

\section{B.2.1. Contexto nacional}

La adopción del neoliberalismo en América Latina y especialmente en Colombia, implicó un cambio en las políticas que marcaron nuevas pautas de relación entre las empresas y sus 
trabajadores. En Colombia este nuevo paradigma estuvo marcado por la apertura económica, la entrada en vigencia de la nueva constitución y la liberalización de la economía. A pesar de que la nueva constitución buscaba la ampliación del alcance de la seguridad social, también permitió emprender reformas a la salud, la educación y la política de vivienda basadas en la privatización y el principio de competencia del mercado. Así se instaló lo que Fernán González (2016) llama estado neoliberal o nuevo paradigma neoestatal. Este nuevo paradigma incluyó la reducción del gasto público, la apertura de los mercados, la flexibilización del mercado laboral "dirigida a evitar las presiones de los salarios, las cargas laborales sobre la rentabilidad, a fin de propiciar la generación de empleo" (Corredor 1995 en González 2014, 406).

El relajamiento de las normas laborales en un contexto de apertura económica facilitó la transferencia de costos y riesgos desde las empresas hacia los trabajadores. Al mismo tiempo, la introducción de una nueva perspectiva económica habilita el abandono de la filantropía y el paternalismo. En este sentido, Milton Friedman sostiene que en el marco de una democracia liberal las empresas sólo deben respetar la ley y ser transparentes. En otras palabras, en un sistema de mercado la única responsabilidad de las empresas es, según este autor, "usar sus recursos y comprometerse en actividades dirigidas a incrementar sus beneficios siempre y cuando estén dentro de las reglas de juego, que es lo mismo que decir que participen en una competencia abierta y libre, sin decepción o fraude" (Friedman 1970, 141 en Herrera 2011, 168).

Los ingenios colombianos no abandonaron su relación asistencialista con los trabajadores y las comunidades aledañas. La asistencia fue cambiando hasta convertirse en grandes programas de RSE dirigidos a los distintos grupos de interés (trabajadores y sus familias, comunidad, entorno, entre otros), que le permitía tener una actuación legítima en la región. Continuaron con actividades que parecieran ir más allá de la obtención de beneficios económicos directos y de lo que exige la ley. Incorporaron nuevos enfoques y metodologías manejadas por profesionales, supuestamente más transparentes con respecto a sus criterios, objetivos y resultados. Sin embargo, adoptaron una postura frente a la RSE en la cual la rentabilidad de la empresa no se pone en riesgo. Es más, los programas de RSE deben aportar a la generación de ingresos, o en su defecto a la reducción de costos, para poder ser apoyados 
y promovidos desde la patronal. Paralelamente, aprovecharon la nueva legislación laboral para reducir sus costos, para competir en el mercado nacional e internacional, por medio de la subcontratación y la tercerización.

Esto se combina con las viejas formas de informalidad laboral. Que en Colombia presenta tasas del $70 \%$ en el área urbana y $88 \%$ en el área rural. Además, el $70 \%$ de la población ocupada no tiene cobertura pensional y del 30\% que está cotizando para pensión solo un $10 \%$ se va a jubilar (Observatorio Laboral de la Universidad del Rosario, 2016).

\section{B.2.2. Relación estado-industria azucarera}

En este contexto de políticas neoliberales la relación entre el estado y la industria azucarera en ocasiones ha sido consecuente y en otras ha sido contraria a los intereses empresariales. Por un lado, y de manera alineada a los intereses del sector, desde el gobierno de Álvaro Uribe con el programa de oxigenación de gasolina ${ }^{13}$ se impulsó el cultivo de palma africana y caña de azúcar para la producción de biodiesel y por lo tanto hubo un impulso a la industria azucarera (Urrea Giraldo 2010). Que además se incrementó con el uso obligatorio de este producto en la mezcla con la gasolina que se vende comúnmente.

No obstante, años más tarde la administración del presidente Juan Manuel Santos a través de la Superintendencia de Industria y Comercio en 2015 se impuso multas en contra de la cartelización a doce ingenios, a Ciamsa, Dicsa y Asocaña. Y en 2017 multó nuevamente un ingenio y a varias empresas asociadas a este por tercerización laboral ilegal a través del Ministerio de Trabajo.

Llama la atención que esta multa evidencia un reconocimiento institucional del corte de caña y especialmente de la importancia de los corteros en el proceso de producción de azúcar y demás productos. El Ministerio (2017) se basó en el supuesto de que el corte de caña es una actividad misional permanente en el ingenio y por lo tanto la tercerización resulta ilegal, pues la producción del azúcar y sus derivados comienzan por la adquisición del terreno

\footnotetext{
${ }^{13}$ Gracias al Programa de Oxigenación de la Gasolina, política gubernamental, y a la inversión del sector privado, que solo en el Valle del Cauca asciende a 255 millones de dólares en 6 destilerías, Colombia es hoy el tercer país productor de bioetanol en América Latina, después de Brasil y Argentina (El Tiempo 2017). En 2015 se produjo en conjunto 456 millones de litros (Asocaña 2017). El precio del etanol producido por la industria azucarera es mucho más caro que el de países como Brasil o Estados Unidos por los subsidios que reciben los productores en estos países y que afectan el precio final por galón (Portafolio 2012).
} 
o de la caña en mata e implica un arduo trabajo referente al cultivo, la cosecha, el corte y el transporte.

\section{B.2.3 Legislación que permite la tercerización}

El gremio azucarero en su proceso de tercerización laboral ha combinado varias formas de subcontratación de los corteros de caña tales como los contratistas, las cooperativas de trabajo asociado (CTA), las empresas asociativas de trabajo (EAT) y el contrato sindical, entre otras. Hacia el 2006, el 90\% de los 16 mil corteros que había en la región pertenecía a alguna cooperativa (Aricarpa 2006, 4). Estas cooperativas y las posibilidades laborales asociadas a ellas se dieron, en algunos casos, en detrimento de la vinculación directa a las empresas y los derechos laborales estipulados por ley. Además, introdujeron elementos de inestabilidad laboral que afectaron a los trabajadores (Ronderos 2011).

Según Jaramillo, director del Observatorio Laboral de la Universidad del Rosario, hay cuatro hitos que regulan normativamente la tercerización laboral en el país: el artículo 34 del Código Sustantivo del Trabajo de 1950, el artículo 63 de la Ley 1429 de 2010, el Decreto 583 de 2016 y la Resolución 5670 de 2016 (Daniel Jaramillo: 15 de agosto de 2017). En el artículo 34 del Código se define a los contratistas independientes:

[Son] verdaderos patronos y no representantes ni intermediarios, las personas naturales o jurídicas que contraten la ejecución de una o varias obras o la prestación de servicios en beneficios de terceros, por un precio determinado, asumiendo todos los riesgos, para realizarlos con sus propios medios y con libertad y autonomía técnica y directiva.

Sin embargo, según el Decreto 583 de 2016 se considera ilegal que una institución o empresa pública o privada vincule personal para el desarrollo de actividades permanentes a través de un tercero contratista. Además, la Resolución 5670 de 2016 del Ministerio del Trabajo toma medidas para que las entidades responsables puedan ejercer control sobre la tercerización e intermediación laboral.

En cuanto al contexto normativo Aricarpa (2006) afirma que la Ley 50 de 1990 es un antecedente del proceso de tercerización laboral en los ingenios, pues aunque esta respeta la 
antigüedad de los trabajadores, la ley les permitía que renunciaran a su antigüedad y se acogieran a las nuevas formas de cálculo de salarios y cesantías independientes del tiempo laborado en la empresa. En este proceso de tránsito a la ley 50 muchos corteros renunciaron (o fueron obligados a renunciar) a los ingenios a cambio de una suma de dinero y la promesa de continuar trabajando a través de contratistas (Aricarpa 2006, 14).

Según el Observatorio del Mercado del Trabajo, las CTA surgen con la Ley 134 de 1931, después se regulan con la expedición de dos decretos en el año 1953 y 1958 bajo el nombre de cooperativas de producción y trabajo. Pero solamente la Ley 79 de 1988 y el Decreto 468 de 1990 fijaron el marco jurídico y regularon las actividades propias de las CTA. En teoría esta figura surge para facilitar el ejercicio laboral con poco capital y de manera solidaria a través de beneficios tributarios, pero sus asociados (trabajadores) renuncian a la protección especial que la legislación laboral brinda a los trabajadores asalariados (Observatorio del Mercado del Trabajo 2007, 12).

En este sentido, las cooperativas se utilizaron para cambiar la figura de dependencia “empresa-asalariados por una del tipo cliente-asociados de las CTA, sin mayores cambios de orden productivo, organizacional, ni jerárquico. No hay propiedad de los medios de producción por parte de los trabajadores asociados y menos aún, un manejo autogestionario ni autónomo" (Observatorio del mercado de trabajo 2007, 17). Lo cual iría en contravía del espíritu cooperativo y de la normatividad vigente.

Además, las CTA resultan siendo un problema para los trabajadores porque, primero, las compensaciones tributarias eran asumidas como rentas de trabajo las cuales tenían el mismo tratamiento de los salarios, pero no tenían trato prioritario respecto de otros acreedores. Y, segundo, los asociados son tratados por el estado como asalariados para la afiliación al sistema de compensación familiar, pero son tratados como independientes al momento de cotizar a pensiones y salud. Por último, frente a los riesgos profesionales son tratados como independientes atípicos, y por tanto están obligados a cotizar (Observatorio del mercado de trabajo 2007, 27).

Una segunda forma de subcontratación legal se observa con el Decreto 1100 en su artículo $2^{\circ}$, el cual reglamentan las empresas de trabajo asociado (EAT). Empresas que según Aricarpa (2006), no pueden tener más de 20 miembros, cada uno debe aportar su capacidad 
productiva, representada en bienes muebles e inmuebles, o en dinero para la constitución del capital semilla de la empresa. Al final, las EAT reparten las utilidades proporcionalmente a los aportes de cada uno de los socios y estas utilidades están exentas hasta en un $50 \%$ del pago de impuestos.

En tercer lugar, existe la subcontratación legal por contrato sindical, regulada por el Decreto 1429 de 2010. En este caso, los sindicatos emplean trabajadores con los cuales prestan un servicio a un tercero. Ese tercero puede ser la propia empresa en la que opera el sindicato u otras distintas (Aricarpa 2006, 17). La particularidad de esta forma de subcontratación consiste en que los trabajadores deben afiliarse al sindicato y aportar la cuota sindical, pero la convención colectiva del sindicato con la empresa no les cobija.

Según Aricarpa (2006) son sindicalizados pero no gozan de todos los derechos sindicales. En este caso, la relación laboral se rige por los estatutos del sindicato, que en ocasiones puede dar pie a la evasión del pago de las vacaciones o las cesantías. "Esto contra la evidencia de que existe una relación laboral completa, toda vez que se conjugan los tres elementos que la configuran: trabajo unipersonal, remuneración y subordinación" (Escuela Nacional Sindical 2014, 47).

Finalmente, como se verá en este caso también existen las empresas subcontratistas. Es decir, empresas creadas por terceros actores distintos a los ingenios que son los encargados de contratar a los trabajadores para venderle la mano de obra a las empresas. En la industria azucarera esto se observa en los contratistas que estuvieron presentes antes del paro del 2005 y hoy en las empresas de corte que son sociedades anónimas. 


\section{Capítulo 2. Relaciones laborales: ingenios, sindicatos y corteros de caña}

El objetivo de este capítulo es dar cuenta de los cambios en la relación entre los ingenios y los corteros de caña, a través de los hitos que han marcado esta relación. Además, se muestra el papel que han jugado los sindicatos como un tercer actor en la relación entre los corteros y los ingenios. Para el desarrollo de este capítulo se proponen tres apartados. El primero caracteriza la construcción de narrativas basadas en imaginarios de raza y clase que se han tejido alrededor de los corteros de caña desde la administración de los ingenios. Dichas narrativas han funcionado como una válvula de escape que en ocasiones ha sido utilizada para justificar los fracasos de la tercerización laboral, pasando la carga de la culpa a los corteros y quitando todo tipo de responsabilidad a los ingenios que en principio tomaron la decisión de tercerizar.

El segundo es un recuento de los cambios que se han dado en la relación entre el ingenio y los corteros. Una de las consecuencias que más afecta a los corteros es el paso de una relación laboral a una de tipo comercial. Ya que se utilizan distintas modalidades para convertir a los corteros en proveedores de caña de azúcar, en vez de contratarlos como trabajadores directos de los ingenios. Esto ha obligado a los corteros a buscar nuevos espacios para tramitar los conflictos, como la negociación con funcionarios que aplican programas de RSE creados exclusivamente para los proveedores y la comunidad. En el tercero se propone una descripción del accionar de los sindicatos alrededor de los paros. Pero se remite a épocas anteriores de surgimiento y consolidación del sindicalismo en los ingenios.

Este capítulo se articula alrededor de los paros de corteros del 2005 y 2008 y las distintas formas de contratación presentes en la industria antes, durante y después de estos hitos. No obstante las narrativas de otredad se construyen a partir de las narraciones que realizan trabajadores actuales y antiguos sobre la población de los corteros y se remiten a aquellos primeros trabajadores afrodescendientes que migraron del Pacífico a trabajar en el corte de caña a mediados del siglo XX.

\section{C.1. Construcción de narrativas de otredad e ingenios como agentes civilizatorios}

La construcción de narrativas de otredad basadas en imaginarios de raza y clase tejidas alrededor de los corteros de caña desde la administración de los ingenios han sido utilizadas como una válvula de escape para justificar los fracasos de la tercerización laboral. Para 
explicar esta idea este subcapítulo se estructura a partir de dos partes: primero, se describen los corteros y su oficio y se indica cómo los ingenios utilizan estas narrativas para justificar su actuación como un agente civilizatorio; segundo, se muestran cómo se construyen estas narrativas.

\section{C.1.1 Corteros y el oficio de cortar de caña}

Quienes ejercen el oficio de cortar caña son llamados corteros. Los ingenios envían buses para recogerlos de sus casas y llevarlos hasta los cañaduzales donde se va a trabajar esa jornada. El corte comienza alrededor de las 6:30 de la mañana y termina en las horas de la tarde. Los corteros utilizan machetes muy afilados que liman constantemente para poder abatir la caña. Para que la caña quede bien cortada deben desbastarla al ras del suelo una a una. Es un trabajo arduo porque durante todo el proceso el cortero debe permanecer agachado, tirando fuerte de la planta. Después del corte, apilan la caña para que la máquina alzadora la recoja y la ponga en los trenes cañeros que la transportan hasta los ingenios.

Como se paga a destajo, su salario depende de su destreza en el corte lo cual causa que no todas las personas ganen lo mismo por el trabajo. El salario varía entre un cortero y otro. "Las contrataciones a destajo por obra o labor realizada, tienen ventajas y desventajas, pues por una parte promueven la actividad por individuo, por la otra se dan situaciones de desequilibrio entre los mismos corteros" (Adolfo: 27 de julio de 2017).

Le pagan lo que uno se hace. O sea, que tú de pronto eres un cortero y yo soy otro cortero y yo apreté el machete y me fui 20 toneladas en la semana y tú metes 10. Entonces claro tampoco te da y como se paga es al destajo, lo que uno se haga, entonces pues varias personas no les daba el rendimiento y entonces esas personas se sentían afectadas económicamente (León Aguirre: 4 de agosto de 2015).

Hacia la segunda mitad del siglo XX, numerosos corteros provenían de zonas del país como el Pacífico y en su mayoría eran afrocolombianos. En algunas ocasiones, según Andrés Castro, presidente de un sindicato de industria, los ingenios enviaban emisarios al departamento de Nariño con el fin de conseguir entre 50 y 100 trabajadores por viaje para el corte de caña. Estas personas llegaban a trabajar a los ingenios donde cambiaba por completo su estilo de vida. Los entrevistados dicen que estos trabajadores dejaban de ser campesinos 
o pescadores y pasaban a ser trabajadores asalariados.

Al migrar a los ingenios les tocaba llegar a vivir en campamentos que no siempre tenían las condiciones necesarias para una vida digna (Andrés Castro: 21 de julio de 2015). Para el caso del Ingenio Verde, el padre Juan Pardo cuenta que los corteros llegaban a trabajar ahí junto a sus familias o iban formando sus propias familias alrededor de los ingenios donde vivían en "pocilgas inmundas, viviendo en campamentos como unos esclavos de hace 200 años" (Juan Pardo, sacerdote: 7 de julio de 2015).

Recuerdo que un día estaba yo almorzando, yo almorzaba del arrocito que me daban los trabajadores en los campamentos. Se levantó un hombre que se llamaba John Hinestrosa un moreno, alto, analfabeta y me dice: "padre Pardo, por nosotros no se molesté usted más. Si puede haga algo para que nuestros hijos no corran la perra suerte que hemos corrido nosotros" (Juan Pardo: 7 de julio de 2015).

Según Carolina Trujillo su origen campesino o relacionado con los oficios del campo era, y aún hoy es un problema, porque estaban acostumbrados a trabajar en otros horarios diferentes a los exigidos y aceptados por los ingenios y para ella, eso influye en el abandono del puesto de trabajo (Carolina, trabajadora social de El Dorado: 30 de junio de 2015). En este sentido, Andrés sugiere que "El ausentismo laboral [es] un problema cultural. De pronto la alegría de las personas, el consumo de licor hace que [...] sean un poco irresponsables en cuanto a presentar[se] a laborar y al cumplimiento de un contrato de trabajo" (21 de julio de 2015).

No obstante, en el marco del modelo paternalista tradicional estos trabajadores pasaron por varias fases de procesos educativos que Urrea-Giraldo (2007) denomina como un proceso civilizatorio en los ingenios. Por ejemplo, Humberto, inició su carrera laboral en el corte de caña y hoy es supervisor de aplicación de compost. Entró a trabajar en El Centenario cuando tenía 18 ó 19 años de edad. Comenzó a trabajar como cortero a "por medio de contrato", después le suspendieron el contrato de cortero y el ingenio le dio la oportunidad de entrar a trabajar en "la ministra"14. Luego pasó a manejar un tractor, de ahí a ser

\footnotetext{
${ }^{14}$ La ministra, según Urrea Giraldo (2007) constituye un nuevo cargo que se les otorgó a aquellos corteros que no aceptaron retirarse de manera voluntaria a través de una bonificación para compensar el retiro por parte del ingenio. Es un cargo de oficios varios que para muchos trabajadores se ve como una pérdida de un trabajo especializado para convertirse en un "comodín errante". En este nuevo trabajo se ganan el mínimo y no es
} 
mayordomo y por último a ser supervisor. Para salir de la ministra, Humberto accedió a los procesos de aprendizaje por ciclos del ingenio para terminar el bachillerato y una tecnología (Humberto, supervisor aplicación compost, 16 de octubre de 2015).

Igualmente León, líder del paro de corteros del 2008, entró a trabajar como cortero habiendo alcanzado solo el noveno año. Por medio de la cooperativa en que trabajó pudo terminar el bachillerato los días sábados. Después, a través del Sena aprendió a soldar y hoy en día trabaja en este y otros oficios varios en el ingenio (León Aguirre, líder del paro de corteros del 2008, hoy contratista de El Centenario: 4 de agosto de 2015). Asimismo, Héctor Vaca entró a trabajar con una contratista llamada Viviana Gonzales en El Centenario en 1998 y terminó el colegio por medio de los programas del ingenio (Héctor Vaca, monitor de corte que inició como cortero: 16 de octubre de 2015).

Muchas de las opiniones recolectadas a través de las entrevistas en profundidad y expuestas en el apartado anterior responden a imaginarios de raza y clase de personas que trabajan en los ingenios y que hablan de los corteros como un otro que se construye como tal a través de su racialización. Un proceso de coproducción e inscripción de otros (diferentes/marcados) y nosotros (diferentes/no-marcados) en un entramado social de exclusiones e inclusiones propias de la dialéctica de reproducción/contestación permanente de la hegemonía y subalternadidad (Restrepo 2002).

Estos imaginarios de raza y clase han sido la base para la construcción de narrativas de otredad utilizadas por los ingenios de diferentes maneras en diferentes contextos para justificar sus acciones o ausencia de las mismas con respecto a los corteros. Un ejemplo de esto es lo que Urrea Giraldo (2007), en su texto La rápida expansión de las cooperativas de trabajo asociado, propuso para analizar un ingenio como un agente civilizatorio, que se pone en marcha a través de programas educativos que han estado presentes desde la fundación de los ingenios ya sea a través de la iglesia católica, los dueños o sus familiares o de las burocracias propias de la RSE.

posible ganar por horas extras adicionales. Además los trabajadores que están en la ministra pierden los beneficios de los trabajadores de planta (Urrea Giraldo 2007, 149). 
En este caso existe un colegio desde que se fundó el ingenio y, en principio, tenía como propósito alfabetizar a los trabajadores, pero con el paso del tiempo este se convirtió en un colegio grande que terminó como un proyecto de educación para los hijos de sus trabajadores. Debido al cambio de la función del colegio se abrió un nuevo espacio para los trabajadores los días sábados, para que pudieran terminar el bachillerato u otros cursos que ahí se ofrecen.

Este es un proceso similar al de El Centenario, donde hoy hay un colegio para los niños de los trabajadores y de la región en general y uno para los trabajadores que necesiten terminar sus estudios, así como carreras técnicas y tecnológicas. En ese sentido, podría decirse que este proceso civilizatorio descrito por Urrea-Giraldo puede ser comparable al proceso de El Centenario que se da en todas las fases de los procesos educativos a los que acceden los trabajadores y sus hijos.

La mayor parte de los hijos de los trabajadores antiguos (corteros de caña, operarios de maquinaria agrícola, transportadores de caña, mecánicos, obreros de fábrica en oficios especializados y no especializados) y del cuerpo de empleados y funcionarios medios, profesionales y técnicos del aparato burocrático (administradores, contadores, auxiliares contables, secretarias), han realizado la totalidad del proceso educativo, desde la primaria hasta el bachillerato, en el Colegio. Se trata de una institución educativa fundada en el año 1952 como escuela para obreros, y que posteriormente, a raíz de que la empresa construyera las instalaciones físicas en predios de la misma, se transformaría en un colegio privado para los hijos de empleados y trabajadores del Ingenio El Centenario, con el propósito de "formar hombres de bien para la sociedad" (Urrea Giraldo 2007, 155).

Esto sirve como un punto de partida para entender el paso de los corteros, de un mundo campesino o rural a uno asalariado, donde el ingenio juega un papel fundamental de disciplinamiento de la mano de obra en términos de control de horarios, condiciones de trabajo y de vida, etc.; y proceso de civilización a través de la educación que ha ido cambiando desde la época clásica paternalista, pero que ha sido reformado y retomado desde programas de RSE creados según los ingenios para evitar el consumo de alcohol, de sustancias psicoactivas, de mejoras en el uso del dinero, entre otros programas. A través de 
estas narrativas, se justificaba la necesidad de la existencia de estos procesos civilizatorios donde se asume que los trabajadores son incapaces de previsión y ahorro (Valero 2013).

\section{C.1.2. Narrativas de otredad basadas en imaginarios de analfabetismo, manejo del dinero, vicios y sus familias}

Dentro de la construcción de narrativas de otredad resalta la del imaginario de la alta tasa de analfabetismo de los corteros de caña de azúcar que está presente en los discursos del gerente, los empleados de la RSE, el padre, las trabajadoras sociales y algunos sindicalistas. Pues esta ha sido utilizada por los ingenios como justificación para explicar la falla de los procesos de tercerización a los que fueron sometidos desde inicios del 2000 y para implementar de manera vertical procesos educativos que van desde bachillerato hasta cursos de manejo de dinero implementados por padres y monjas o por grupos especializados de RSE según la época. Estos imaginarios se construyen alrededor de que muchos de los corteros de caña son o eran analfabetas o analfabetas funcionales.

Ernesto quien inició su carrera laboral como cortero y hoy en día trabaja en Servicios de Cosecha Dorado, afirma que los corteros son un grupo que, "en cuanto a la educación, [tiene] un nivel muy bajo. Hay muchos que escasamente tienen una primaria y algunos no alcanzan a tener la primaria. Eso lleva a que [...] se dejen manipular, porque no todos tienen pues la apreciación" (Ernesto Lopera, supervisor de corteros e inició como cortero: 28 de diciembre de 2016). Estas narrativas ponen el énfasis en los atributos físicos de las personas y los prejuicios que se tejen alrededor de los mismos y dejan de lado las formas propias de representación de los corteros.

Desde la administración de los ingenios además existe una preocupación por el supuesto mal manejo del dinero. Según el tesorero de Sintradorado, existe una alta tasa de endeudamiento entre este grupo de trabajadores (Jaime Salazar, tesorero de Sintradorado: 9 de julio de 2015) en muchos casos por medio de prestamistas "gota a gota". Dado que los corteros no tienen una vida crediticia que les permita acceder a créditos formales con los bancos, buscan préstamos por medio de los gota a gota.

Uno hace un análisis en el sector del gremio de corte y el endeudamiento es altísimo. A pesar de que se pone a mirar uno el cortero del ingenio El Dorado gana alrededor de 1.200.000, pero no les alcanza. Hay un método que utilizan mucho y es préstamos callejeros. Pero dejando la tarjeta con que cobran, ellos se 
la dejan a un prestamista y ellos le prestan a un $10 \%$ semanal y pues le prestan 100 mil y semanalmente le descuento 10 mil pesos. Entonces digamos que eso es la cultura que está ahí, que es muy difícil de erradicar de ellos, es algo de ellos, es un problema de ellos (Ernesto Lopera: 28 de diciembre de 2016).

Quienes acceden a estos préstamos saben que los intereses son cercanos al $20 \%$ del total prestado y que les será cobrado por día, por semana o por mes, según el prestamista o el acuerdo; además solamente se necesita firmar una letra de pago y/o presentar los datos de codeudores. Esto ha sido utilizado como una forma de control a los trabajadores. Por ejemplo en la época de los contratistas se les hicieron descuentos correspondientes a salud y a pensión que no llegaron a su destino. Y en la misma época los contratistas utilizaban el endeudamiento para "enganchar" a los trabajadores y asegurarse la mano de obra para la siguiente quincena. Además esta idea de incapacidad de hacer un buen manejo del dinero ha sido utilizada desde la época clásica paternalista por los dueños de los ingenios, los padres y monjas y hoy por los funcionarios de la RSE para justificar la necesidad de cursos y programas encaminados a enseñarles a valorar el dinero, su buen uso y el ahorro.

Otro mecanismo de construcción de la otredad es el de los vicios de los corteros que están íntimamente ligados a la supuesta incapacidad del manejo del dinero. Para Ernesto Lopera los corteros "apenas sienten que tienen una deuda moderada, vuelven otra vez ¿por qué?, porque el consumo de alcohol en estas personas es muy alto" (Ernesto Lopera: 28 de diciembre de 2016). De hecho en El Centenario Miriam Salazar, directora del área de bienestar social, justificó la existencia de un grupo de corteros contratados directamente por el ingenio y otro por empresas de corte por medio de estas narrativas:

La otra filial que hay [Centenario Corte] esa si es la que de pronto, todavía, se resiste a cosas como "no, no quiero ir a trabajar hoy" y me quedé tomando, entonces se suspenden [...] No les interesa ser directos, porque todavía tienen en la cabeza de que no le hacen caso a nadie. Porque el cortero anteriormente trabajaba dos días y tomaba tres (Miriam Salazar: 4 de agosto de 2015).

En la construcción de los imaginarios de raza y clase, Miriam Salazar cuenta que cuando ella entró a trabajar a El Centenario llegaban a las puertas del ingenio las esposas de 
los corteros con el ojo reventado o golpeadas. Una de sus primeras funciones fue hacer una “intervención con esas señoras y salió otro programa que, también manejo yo, la Fuerza del Hogar, que es una charla que yo directamente hago, todos los jueves, con los trabajadores y sus esposas" (Miriam Salazar: 4 de agosto de 2015. Cursivas agregadas). Así, los problemas familiares también han sido utilizados para justificar intervenciones desde programas de RSE enfocados al trabajo con la familia. Estos en ocasiones terminan dejando efectos adversos como el ensanchamiento de control de la vida de los trabajadores, destinatarios de dichos programas, por parte del ingenio a través de los empleados que ponen en marcha la RSE.

Estas narrativas además se basan en reforzar prejuicios e imaginarios asociados a los corteros como la "falta de cultura o vicios" (Alejandro Rengifo: 8 de julio de 2015). Que además se constituyen de manera parcial, pero ayudan a la creación de otro al que se le atribuyen ciertas características que lo hacen parecer como algo único e irrepetible causado por "su cultura" pero desde donde los ingenios desconocen que los corteros no actúan de una u otra manera solo porque son corteros. La corrupción, los vicios, entre otros no son características intrínsecas de ellos como lo quieren hacer ver algunos empleados o directivos de los ingenios.

Bajo esta lógica, el uso de las narrativas de alteridad le permite a los ingenios justificar la tercerización laboral, desde la perspectiva de la culpa de los corteros. Es decir que para las empresas, los corteros, están tercerizados por su propia culpa (porque no saben manejar el dinero, porque son viciosos, porque se roban entre sí) y no porque hacen parte de un amplio proceso de subcontratación que inició a principios de los 2000, y permitió la reducción de costos laborales y la externalización de los riesgos como prácticas corporativas.

\section{C.2. De relación laboral a relación comercial: los ingenios y los corteros}

En este subcapítulo se pretende hacer un recuento de las diferentes formas en que se han relacionado los corteros y los ingenios desde el año 2000, los hitos que han marcado dichas relaciones y las respuestas empresariales. El cambio más importante en esta relación es que dejó de ser de carácter laboral y pasó a ser una de carácter comercial, que ante todo, está regida por las leyes del mercado y no las del Código Sustantivo del Trabajo. Según Urrea Giraldo (2007), la transición entre las distintas formas de contratación no fue homogénea, en ocasiones entre un tipo de contrato y otro se emprendió una competencia que favorecía 
procesos de deterioro en la contratación, por ejemplo según el autor, los sindicatos y las cooperativas de trabajo competían entre sí para pagarle menos a los corteros con el fin de obtener más ganancias. No obstante, al final quienes más se beneficiaron por el proceso de tercerización fueron los ingenios, que en este caso, son los patrones reales.

Este subcapítulo tiene tres apartados. El primero tiene como objetivo mostrar la forma en que los corteros pasaron de ser trabajadores a proveedores de caña de azúcar. Para lograr esto se indican los diferentes tipos de contrato que tuvieron los corteros y las condiciones laborales asociadas a dichos contratos. Así como señalar las dos grandes huelgas del 2005 y 2008 y las respuestas contractuales de los ingenios a estas manifestaciones.

El segundo apartado tiene como objetivo analizar el establecimiento de empresas de corte a través de las cuales se subcontratan a los corteros hoy en día, las cuales permiten que se establezca un tratamiento como proveedores a través de la RSE. Y por último, exponer la adhesión al Pacto Global como una respuesta de las empresas frente a la sociedad civil que demandaba soluciones frente a la precaria situación laboral evidenciada después de los dos paros.

\section{C.2.1. Las distintas formas de contratación en el proceso de tercerización laboral y los paros del 2005 y 2008}

Los corteros han tenido todo tipo de contratos directos e indirectos. Durante un mismo período han coexistido dos o más formas de contratación. Sin embargo, los contratos directos son cada vez más escasos. No obstante en este proceso no hubo despidos masivos, pero se aplicó la Ley 50 de 1990, los pasaron a la "ministra", se jubilaron de manera temprana, aceptaron el retiro voluntario de la empresa por medio de compensaciones, o "fueron ubicándose, algunos jubilándose, otros retirándose, otros ascendiendo. Yo creo que el cortero existió directo como hasta los años 2000” (Ernesto Lopera: 28 de diciembre de 2016).

Hacia la segunda mitad de la década de los noventa, varios ingenios comenzaron un proceso de reestructuración que tenía como propósito aumentar la productividad a través de la reducción de mano de obra, específicamente, de corteros de caña, que son el oficio menos especializado de la cadena de producción (Urrea Giraldo 2007, 149). En El Centenario, un dirigente sindicalista, afirma que "se negoció una indemnización con los trabajadores para que estos salieran de la empresa a trabajar con contratistas, empresas asociativas, para llevar 
a cabo un proyecto productivo" (José Aragón, presidente de Sintraindulce: 4 de agosto de 2015) o para trabajar en oficios varios dentro del ingenio.

Urrea Giraldo (2007) explica que el proceso de subcontratación en los ingenios en un principio estuvo enfocado en el uso de contratistas, de empresas asociativas de trabajo y/o de contratos sindicales antes del paro del 2005. En el año 2001 entre el ingenio El Centenario y el Sindicato Sintrazúcar se suscribió un contrato sindical. José Aragón, directivo sindical en El Centenario y suscriptor del contrato mencionado, describe uno de los beneficios de este tipo de contratación, mercados básicos para los corteros y sus familias:

De que el cortero de caña le dábamos siete libras de arroz semanales para una familia eso es un exabrupto. Para ellos, el cortero de caña, nos dimos cuenta que ellos llevan la olla grande, la olla de libra, porque ellos llevan su libra de arroz y el complemento. Los que tienen carne, carne, los que tienen huevo, pescado o lo que sea. Es una libra de arroz para el trabajo. Entonces ellos nos decían miren ustedes van a matar de hambre a mi familia. Cómo así hermano, ¿pero no le estamos dando?, "no, eso es lo mío de trabajar y ellos qué". Vamos a tener que echar el jabón vamos a tener que echar la crema, porque dentro de lo que nosotros hicimos era que en todos los mercados iba un jabón de olor y una crema dental y papel higiénico y resulta que nos damos cuenta que ellos nunca habían utilizado eso ¡Increíble! [...] Ni crema, ni jabón de olor. Ellos utilizaban era el jabón azul y con eso hacían todo (José Aragón: 4 de agosto de 2015).

Estas narrativas de otredad se basan en imaginarios de raza y clase que evidencian cómo se utilizan estos discursos para justificar la actuación o no de los distintos actores culpables de la tercerización. A pesar de las críticas al contrato sindical, José Aragón justifica esta forma de subcontratación indicando que lo que se buscaba era que estuvieran protegidos por el sindicato, pues automáticamente quedaban afiliados como trabajadores a este. Además tenían un contrato laboral, eran afiliados a la EPS, la ARL, al fondo de pensiones y a la cooperativa de trabajadores y podían ahorrar y contar con un seguro funerario. No obstante una de las exigencias para levantar el paro del 2005 era la cancelación de los contratos sindicales, lo cual es una muestra de que el objetivo de proteger a los trabajadores se desdibuja en la desconexión entre el sindicato y sus representados.

Para la primera mitad de la década de 2000 además de contrato sindical y empresas asociativas de trabajo (EAT) había también contratistas, como la Señora Viviana Gonzales, 
con quienes los ingenios acordaban el suministro de mano de obra para el corte de caña. Bajo esta modalidad de contratación, que era la más común de todas, se empezaron a presentar problemas en cuanto a las condiciones laborales, una de las más graves eran los aportes a salud y a pensión. A los corteros les hacían los descuentos que corresponden por ley a su salario, sin embargo los contratistas no siempre aportaban el dinero a la EPS ni al fondo de pensión. Cuando los trabajadores necesitaban servicio médico, al acudir a la EPS, se encontraban con la noticia de que los contratistas solo habían pagado una semana del mes, lo cual generaba inconvenientes al momento de la atención.

En cuanto al fondo de pensiones hasta hoy persisten los problemas. Hay trabajadores mayores que no han podido pensionarse, porque aunque les descontaban mensualmente sus aportes, estos nunca llegaron a su destino (Ernesto Lopera: 28 de diciembre de 2016). "Esto ha generado controversias judiciales de importancia, que no siempre han sido resueltas en favor de los trabajadores de corte" (Adolfo Madrid: 27 de julio de 2017).

Otro de los grandes problemas presentados en la época de los contratistas fue el del horario laboral. Los corteros llegaban a sus lugares de trabajo a las 6 de la mañana pero no sabían a qué hora podían retirarse, en ocasiones "ellos [los contratistas] a la hora de salida decían que se tenían que quedar a terminar de cortar, porque si no, pues sencillamente no había más trabajo. En el lenguaje cotidiano se llama no hay ficha” (Ernesto Lopera: 28 de diciembre de 2016).

Además, al terminar el año los corteros sufrían por la incertidumbre de no saber si el contrato sería renovado o no. Cada diciembre se liquidaban en su totalidad las cesantías que correspondían por su trabajo a cada trabajador, estas las recibían en efectivo al terminar el contrato. En la liquidación iban incluidas las vacaciones, por tanto por el periodo laborado los corteros no tenían derecho al descanso. Toda la plata correspondiente a las primas, cesantías y salario era gastado en navidad y ellos empezaban el año, nuevamente, "limpios" y esta fue una de las razones que llevaron a los corteros al paro del 2005 (Ernesto Lopera: 28 de diciembre de 2016).

Las tiendas de raya o almacenes de grano fueron, en su momento, una práctica muy usual utilizada por contratistas para venderles a los corteros a crédito. Era usual que a los corteros la plata de la quincena se les acabara antes del siguiente pago, la necesidad de alimentar a su familia los obligaba a recurrir a dichas tiendas (Aricarpa 2006, 15). "Por 
ejemplo una arroba de arroz podía valer, digamos, 8 mil pesos en los supermercados y el contratista lo vendía a 12" (León Aguirre: 4 de agosto de 2015). En estas tiendas no solo vendían a crédito sino que prestaban plata a altos intereses, vendían ropa y electrodomésticos (José Aragón: 4 de agosto de 2015). El problema no era solo que los productos los vendieran más caros, sino que una vez adentro era casi imposible salirse:

Si tú comprabas una remesa ${ }^{15}$ en el granero de los contratistas y eso, ya quedabas allí. Porque no te daba el pago, como para tu salirte del contratista. Claro entonces ya le tocaba quedarse ahí. O sea le descontaban eso y otra vez le tocaba mercar otra remesa, ¿si me entiende? [...] O sea, porque digamos que tú te ganabas 300 del pago y te descuentan la remesa que valía 200, te venían quedando como 100 y ya esos 100 mil pesos no te daban para comprar en otro lado. Entonces tenías que comprar otra vez la remesa (León Aguirre: 4 de agosto de 2015).

"Esto se convertía en un perverso círculo vicioso" (Adolfo Madrid: 27 de julio de 2017). Muchas veces las personas, por necesidad, debían ir a estas tiendas "y del mismo sueldo que nosotros ganábamos, el descuento iba por delante" (Héctor Vaca: 16 de octubre de 2015). El descuento al salario del cortero por la deuda era una imposición de los contratistas y "si te gusta bien y si no pues vaya busque trabajo en otra parte" (Andrés Castro: 21 de julio de 2015). En ocasiones, los corteros podían terminar con deudas que comprometían su sueldo de los próximos dos y hasta tres meses (José Aragón: 4 de agosto de 2015). Esta precariedad en las condiciones laborales fueron abonando el camino para el paro del 2005 donde se pedía acabar con las formas de tercerización existentes en aquel momento (EAT, contrato sindical y contratistas).

Las condiciones de trabajo de lo corteros promovían el descontento generalizado hacia este sistema de contratación, ellos sentían "que el contratista se estaba quedando con todo" (León Aguirre: 4 de agosto de 2015). Además, "la gente cree que la empresa no está, se siente totalmente, que le faltan arandelas al proceso, que quieren que les paguen un poquito más, que se hagan mejores acuerdos" (Héctor Vaca: 16 de octubre de 2015).

En el 2005 "nueve de trece ingenios se vieron afectados en el primer paro de los corteros. Pero ese se hizo de manera individual, a nivel de cada empresa. Comenzó en uno y luego se dieron otros fenómenos y se fue repitiendo" (Andrés Castro: 21 de julio de 2015).

\footnotetext{
${ }^{15}$ En el Valle del Cauca "comprar una remesa" significa comprar alimentos.
} 
Una de las soluciones para levantar el paro del 2005 fue acabar con las anteriores formas de tercerización y contratar, de ahí en adelante, a los corteros por medio de las cooperativas de trabajo asociado. Estas cooperativas se instauraron después de que culminó el paro del 2005 y se mantuvieron vigentes hasta el 2012.

Entonces fue pues de las únicas opciones que se dieron en su momento. Entonces de estar con un contratista a estar en una cooperativa donde ya los ingenios tenían un compromiso de estar ayudando, asesorando para que las cosas funcionaran y ofrecía ciertas garantías para que fuera funcionable, pues se aceptó de esa manera. ¿Qué se gana allí? de que al menos nosotros íbamos a tener claro de que íbamos a asegurar que al menos nuestro sistema de seguridad social se iba a manejar de la manera que era y se iban realizar las cotizaciones de la manera que era. Entonces fue un gran avance (Ernesto Lopera: 28 de diciembre de 2016).

En el caso del ingenio Mayagüez, descrito por Urrea Giraldo (2007), en este momento habían dos tipos de cooperativas: las viejas y las nuevas. Las viejas era el nombre con el que se distinguían las cinco cooperativas de corteros antiguos de la empresa, con edades superiores a los 50 años y provenientes en su mayoría del departamento de Nariño, la costa Pacífica y algunos municipios del norte del Cauca, y que salieron bajo la modalidad de retiro voluntario con bonificación o se acogieron a la pensión anticipada. La empresa los vinculó posteriormente por medio de CTA. Estos trabajadores más antiguos tenían trayectorias laborales en la empresa de más de 16 años y antes tenían contratación directa.

Las nuevas eran de trabajadores recién incorporados al Ingenio Mayagüez, los cuales, antes de asociarse en cooperativas, estaban vinculados bajo el modelo de contratista particular. Los trabajadores "nuevos" son en su mayoría hombres en un rango de edad entre 20 y 35 años, nacidos en Candelaria o en alguno de los municipios cercanos (Cali, Palmira, Pradera). En este caso en particular la empresa pagaba mejores precios por tonelada de caña cortada a las cinco cooperativas de antiguos trabajadores (Urrea Giraldo 2007).

En teoría, el modelo cooperativo permitía a sus asociados trabajar para varias empresas, pero en este caso solo trabajaban para una empresa como suministro de mano de obra para el corte de caña, “como no se sabía hacer digamos, de pronto, otra cosa entre los mismos compañeros ¿qué más íbamos a contratar?” (León Aguirre: 4 de agosto de 2015). El salario era a destajo, igual que en la época de los contratistas. El problema se presentaba al final de 
la semana cuando el sueldo solo alcanzaba a "cubrir lo de la seguridad, el transporte, la dotación, entonces le queda muy poquita plata, porque a uno le pagan lo que se hace" (León Aguirre: 4 de agosto de 2015). En este modelo todos eran socios de la cooperativa, en ese sentido hasta los directivos cortaban caña, todo el mundo debía trabajar, porque "nosotros éramos los dueños de nuestra propia empresa, pero ¿qué teníamos nosotros? No teníamos nada" (León Aguirre: 4 de agosto de 2015).

No sé si de pronto mis compañeros también lo analizaron. Porque cuando uno hacía los balances "uy todo ese poco de plata" y cuando ya se iba cada cosa, repartiendo, digamos lo del aporte de seguridad, lo de la caja de compensación, dotación y en todo lo que se iba pagando uno decía uyyy juepucha no queda es nada (León Aguirre: 4 de agosto de 2015).

Entre el 2005 y el 2008, además de las CTA mencionadas, existían sociedades anónimas simplificadas (SAS) que facilitaban la agremiación del grupo de corteros. En El Dorado alcanzaron a existir tres SAS que negociaron contratos de personal con trapiches (Ernesto Lopera: 28 de diciembre de 2016). Sin embargo, el sostenimiento de estas sociedades y de las cooperativas cada vez se hacía más difícil, ya que los asociados querían recibir, como en la época de los contratistas, al final de cada año laboral todo el dinero de sus cesantías, liquidación y demás (Ernesto Lopera: 28 de diciembre de 2016).

En ambos casos, tanto en las CTA como en las SAS, existen problemas de protección a los derechos laborales. En el caso de las cooperativas el salario no era inembargable, estaba sometido a descuentos para sostenimiento de las empresas y muchas veces esto implicaba que el salario que ellos recibían fuera inferior al mínimo. Tampoco tenían derecho a la libre asociación, a la negociación, ni a la huelga. Porque ellos eran los dueños de su propia empresa lo cual implicaba que la huelga se la hicieran a ellos mismos (Escuela Nacional Sindical 2014, 44-5); y como eran los dueños de la empresa cooperativa habrían sido los encargados de resolverlo (Aricarpa 2006 5). Las cooperativas precarizan el trabajo puesto que estas funcionan como bolsas de empleo para la tercerización laboral (Escuela Nacional Sindical 2014, 44-5). Además,

A menudo ellos deben pagar para empezar a trabajar. Este pago toma la forma de un aporte inicial, no reembolsable, con motivo de la afiliación a la CTA y se suma 
a otras dos contribuciones: un monto como aporte a la capitalización de la cooperativa y una cuota obligatoria mensual no inferior al 5\% de la remuneración mensual y puede, en algunos casos, llegar al 10. [Estos trabajadores están en desventaja] ya que no hay indemnizaciones por despido sin justa causa, no hay negociación colectiva y esto termina causando que las empresas-clientes ejerzan un efecto-disciplina sobre sus trabajadores los cuales ya no pueden contar con la representación y apoyo de un sindicato. De hecho dentro de los beneficios que tienen las empresas al contratar de esta manera a sus empleados se ahorra entre un $12-15 \%$ del presupuesto, según lo estimado por el Gobierno, y es por esto que constituyen un definitivo estímulo para la multiplicación de las CTA (Observatorio del mercado de trabajo 2007, 15).

En cuanto a las SAS, "por la poca exigibilidad legal de las obligaciones con sus trabajadores son proclives a los incumplimientos de la normativa laboral" (Adolfo Madrid: 27 de julio de 2017).

Bajo este modelo de contratación y ante los problemas que se les presentaban a los corteros crecía el anhelo por una contratación directa por parte de los ingenios. Una contratación sin intermediarios que por fin les permitiera mejorar las condiciones laborales, razón que también los había enviado a las calles a luchar por sus derechos en el año 2005. Sin embargo, su situación no había mejorado. "Empezó todo eso a moverse y la influencia política también y empezó Ingenio Azul. Y se vino y digamos que llegó a todo el sector y dijimos no queremos cooperativas, queremos contratación directa" (Ernesto Lopera: 28 de diciembre de 2016). Según Urrea-Giraldo (2010) el paro del 2008 de 16 mil corteros es una muestra del resurgimiento de los conflictos obrero-patronales que ha tenido su origen en la implementación de las CTA” (195).

En 2008, los corteros pedían contratación directa, que se acabaran las cooperativas, "porque, en el sistema de trabajo asociado prácticamente ni eran dueños, de los medios de producción, ni tampoco tenían autonomía como tal frente a las decisiones de los empresarios” (Andrés Castro: 21 de julio de 2015). El descontento fue creciendo y se empezó a planear durante nueve meses el nuevo paro. Los corteros se reunían entre ellos, buscaban asesorías tanto de organizaciones sociales como de sindicatos y demás para tomar una decisión informada al momento de llevar a cabo la protesta. Durante la preparación hubo apoyo de políticos, los más recordados son Alexander López y Piedad Córdoba. Como una estrategia de preparación ellos intentaron ahorrar dinero para el sostenimiento del paro, 
Pero si uno vive es como la policía que vive pelao antes y después del pago jajajaja ¿de dónde iba a ahorrar? Sí, entonces si lo único fue los fonditos que tenían las cooperativas, el mismo pago de los fondos de la seguridad social, de los aportes, de ahí fue que echamos mano de lo que había de los aportes. Y pues muy bravo esa situación (León Aguirre: 4 de agosto de 2015).

"El día no me recuerdo, ni la fecha, exactamente, pero yo estaba en el corte cuando todo el mundo pa afuera, pa afuera todo el mundo [...] que llegó la hora cero" (Hernando Galeano: 16 de octubre de 2015). Los corteros se desplazaron hacia las entradas de los ingenios, el paro duró 58 días. León Aguirre, líder de la protesta, lo llamó cese de actividades permanente, mientras que Alejandro Rengifo, gerente de El Dorado lo llamó bloqueo.

Eso fue un bloqueo. Un paro de trabajadores es cuando pertenecen a tu compañía y te hacen una huelga, pero estos trabajadores no eran trabajadores de la compañía. Ellos tenían sus cooperativas, manejadas por ellos y robadas por ellos. Algunas muy bien manejadas y otras desastrosamente manejadas (Alejandro Rengifo: 8 de julio de 2015).

Como se evidencia en la cita anterior para Alejandro Rengifo esta protesta no podía ser reconocida como un paro, pues los corteros no tenían ningún tipo de vinculación laboral con la empresa y esto le daría un status que para los dueños y directivos de los ingenios no podía tener. Esto es una evidencia de que para los corteros tercerizados lo ingenios continuaban siendo los patrones reales. En El Centenario, uno de los líderes del momento invitaba a sus compañeros al diálogo, "entonces yo decía no muchachos no podemos hacer tal cosa, porque de igual manera nosotros trabajamos para El Centenario" (León Aguirre: 4 de agosto de 2015). A pesar de que en ese momento él hiciera parte de una cooperativa que se llamaba San Orlando.

Tanto en El Centenario como en El Dorado el paro se desarrolló a las puertas de los ingenios. Durante esos 58 días "se aguantan necesidades, uno pues se da el dolor, pero las necesidades son tenaces. Nosotros estuvimos casi dos meses y eso es duro. Picándole zancudo a uno allá afuera, porque el paro era aquí afuera del ingenio" (Eder Arzuaga, cortero de El Centenario: 16 de octubre de 2015). Mantener el paro fue difícil, "eso estuvo tremendo, 
eso fue gravísimo. A un compañero le estaban dañando el ojo. Aquí [en el Centenario] un esmad con un cartucho de esos de gases lacrimógenos” (León Aguirre: 4 de agosto de 2015). "Hubieron heridos y todo eso. Como suele pasar en todas las protestas" (Ernesto Lopera: 28 de diciembre de 2016).

Para Alejandro Rengifo, esto se convirtió en un problema porque impedía la libre circulación no solo de los trabajadores del ingenio si no de aquellos que vivían dentro de sus terrenos junto a sus familias. Los corteros bloquearon las entradas y salidas del ingenio y "eso es secuestro. Cuando tú vives dentro de unas instalaciones, tenés tu casa, tu familia y tus hijos y no te dejan salir eso es un secuestro. Estás secuestrada. Eso no es una cárcel eso fue un secuestro" (Alejandro Rengifo: 8 de julio de 2015). En este caso, la tercerización laboral oculta la relación laboral presente entre los ingenios y corteros, mediada por las CTA. Por esto afirmar que era un bloqueo reproduce esa visión, que se mantiene hasta hoy, de que los corteros son proveedores y no trabajadores. Es decir, que no tienen derecho a reclamaciones laborales ni se encuentran protegidos por el Código Sustantivo del Trabajo.

Como se aprecia en el apartado anterior, la interpretación que se hace de la actuación de los corteros es leída a través de imaginarios de raza y clase; que además han sido las justificaciones utilizadas para someterlos a procesos civilizatorios (a través de la educación desde la iglesia católica en la época del paternalismo y desde los empleados de relaciones industriales y gestión humana en la época de la RSE) y de disciplinamiento (control sobre horarios, condiciones de vida, etc.) por parte de los ingenios en principio asociados al paternalismo y hoy en día a la RSE.

A través de mediadores como la iglesia católica, las alcaldías y la gobernación se buscaron alternativas para levantar el paro. Los corteros pedían contratación directa, como primer punto, para sentarse a negociar el pliego de peticiones (Ernesto Lopera: 28 de diciembre de 2016). En el caso de El Centenario había alrededor de 900 corteros eso complicaba aún más la situación, porque no es nada fácil poner de acuerdo a tantas personas (León Aguirre: 4 de agosto de 2015). Aunque en principio, "el enfoque que se tenía era que hubiera una negociación para todo el sector, una sola mesa para todo el sector. No se logró" (Ernesto Lopera: 28 de diciembre de 2016). 
En el caso de El Centenario se llegó a dos acuerdos. El primero de ellos fue la contratación directa y el segundo fue el de la contratación a través de una empresa de corte, como en El Dorado. Esto significa la continuidad de la tercerización, pero con un nuevo nombre. Además este trato personalizado sirvió como una estrategia empresarial para romper el colectivo que organizó y puso en marcha el paro al hablar con cada cortero por separado y no en colectivo.

Porque nosotros lo que hicimos cuando las cooperativas se acabaron fue llamarlos y decirles bueno señores, en el 2008 queremos que ustedes trabajen con nosotros, entonces era lo que decía en ese momento la mentalidad era no, nos van echar. [No] nos van a contratar y lo que van a hacer es engañarnos y sacarnos, porque la mentalidad de ese momento, la gente no entendía que nosotros los necesitamos. Y cómo les vamos a perjudicar si es que la empresa necesita de ellos, o sea cómo va a ser sencillo usted quitar un grupo de personas, si eso está afectando socialmente a mucha gente, a muchas familias, no era así como pensábamos nosotros, pero ellos sí pensaban así. Entonces, así como tu estás hoy allí, entonces era cada uno de nosotros sentado, explicándole a cada uno qué era la empresa, cuáles eran los beneficios y váyase y piense y ya luego volvían y decían si quiero (Miriam Salazar: 4 de agosto de 2015).

La división del grupo de trabajadores, en este caso los corteros de El Centenario, pueden derivar en una estructura dual con múltiples implicaciones en lugares de trabajo, una de las más significativas es la fragmentación del colectivo laboral al establecer distinciones entre lo "trabajadores de las empresas demandantes (efectivos, propios, directos, permanentes, estables, centrales, de planta, fijos) y los trabajadores de las empresas demandadas (tercerizados, indirectos, temporales, no efectivos, inestables, subcontratados, periféricos)" (Basualdo \& Morales 2014, 22).

Las cooperativas de trabajo asociado no llegaron a su fin con el levantamiento del paro en el 2008; estas se acabaron en el año 2012 con la firma del tratado de libre comercio, como lo afirmó Adolfo Madrid (27 de julio de 2017). Las formas de subcontratación que se llevaron a cabo entre los ingenios y los corteros además de todos los problemas que le causaron a los segundos, es una evidencia de que las distintas formas de subcontratación han sido utilizadas como mecanismos de control y disciplinamiento de los trabajadores. Y a pesar de que dichas formas han desaparecido de los ingenios estudiados, la tercerización laboral continúa pero por medio de las empresas de corte. 


\section{C.2.2. El establecimiento de la relación comercial: Servicios de Cosecha Dorado y Centenario Corte}

El fin de las cooperativas se comenzó a negociar en el ingenio Azul, aunque los corteros pedían contratación directa, el ingenio lo hizo a través de otra empresa "adherida al ingenio, empezó allá y ya se vino como el mismo lineamiento en todos los ingenios, en últimas no había más opción" (Ernesto Lopera: 28 de diciembre de 2016). Luego con la imposición del fin de las CTA y de las SAS por parte del gobierno norteamericano a través del TLC, las empresas de corte se convirtieron en la opción predilecta del sector empresarial para contratar a los corteros. La relación entre los ingenios y los corteros se consolidó como una relación netamente comercial y no laboral como los corteros esperaban.

Estas empresas de corte de caña están en varios ingenios. Son empresas pequeñas, con un capital mínimo y están especializadas única y exclusivamente en el corte. Y "si bien no es el $100 \%$ de lo que se esperaba, que era que pasara directamente a la nómina de los ingenios, es un avance comparado a cómo estaba la situación de contratista o posteriormente las cooperativas" (Andrés Castro: 21 de julio de 2015). Por lo menos en esta nueva forma de contratación han sido atendidas en forma correcta las obligaciones empresariales frente al pago de prestaciones y la vinculación a la seguridad social. Además los corteros tienen la oportunidad de asociarse a un sindicato, así estén por fuera del ingenio y de negociar pactos colectivos y pliegos de peticiones aunque menos favorables que los de los trabajadores directos. Alfonso Madrid, indica que en algunos casos incluso se han obtenido algunas mejoras económicas.

Tabla 7 Ingenio y empresas de corte

\begin{tabular}{|l|l|}
\hline \multicolumn{1}{|c|}{ Ingenio } & \multicolumn{1}{c|}{ Empresa de corte } \\
\hline Manuelita & Servicios de Cosecha Manuelita S.A. \\
\hline Mayagüez & Mayaguiez Corte S.A. \\
\hline Pichichi & Pichichi Corte S.A. \\
\hline Incauca & Incauca Servicios Agrícolas y Cosecha S.A. \\
\hline Providencia & Providencia Cosecha y Servicios Agrícolas S.A. \\
\hline
\end{tabular}


No obstante, este modelo permite que la gerencia siga justificando la contratación indirecta:

Mira no es que sean tercerizados. Ellos [los corteros] tienen una compañía que se llama Servicios de Cosecha Dorado y Servicio de Cosecha Dorado nos presta un servicio de corte de caña. Es como la empresa de Aseo de Bogotá que es una empresa que le presta el servicio a la ciudad de Bogotá. Yo no diría tercerizados, yo diría "especializados en" [...] Entonces cada quien se especializa en sus cosas y el salario promedio de un cortero, al bolsillo, son millón 500, millón 600 mil mensuales, al bolsillo ${ }^{16}$. Más prestaciones sociales, más la seguridad social, más todo lo que eso implica, más sus primas y todo lo que tiene como cualquier trabajador de cualquier empresa (Alejandro Rengifo: 8 de julio de 2015).

A pesar de que estas empresas representan ciertas mejoras en las condiciones de vida y de trabajo de los corteros, tienen un gran problema. Estas empresas "prestadoras de servicio" son para Andrés Castro "empresas espejo" que limitan a los trabajadores su derecho a huelga. Son empresas muy pequeñas que no cuentan ni con grandes capitales ni con los medios de producción, simplemente, tiene los elementos que le suministran a los trabajadores para cumplir su labor. Muchas de estas empresas de corte tienen sus oficinas al interior de los ingenios, como en el caso de El Centenario e incluso como en el caso de Servicios de Cosecha Dorado, el ingenio es dueño del $49 \%$ de las acciones, el otro $51 \%$ es de terceros (Alejandro Rengifo: 8 de julio de 2015).

Esto genera que en caso de una huelga, estas empresas no tengan con qué responder, “simplemente pueden ser liquidadas y ya" (Andrés Castro: 21 de julio de 2015). Mientras los ingenios quedan legalmente protegidos del conflicto directo con los corteros. Porque él o los ingenios que son los dueños de la producción "no se ven afectados absolutamente para nada. A él no le pueden hacer la huelga, porque no son trabajadores del ingenio. Son de una empresa que le presta el servicio al ingenio" (Andrés Castro: 21 de julio de 2015).

El Centenario con su objetivo de fragmentación del grupo de trabajadores al mismo tiempo, tiene establecida una empresa de corte, ubicada en una oficina dentro de sus

\footnotetext{
${ }^{16}$ Según Portafolio (2016) los corteros de caña tiene un salario en promedio de 2,8 salarios mínimos legales vigentes, más los beneficios de las convenciones colectivas de trabajo. Según Ernesto Lopera los corteros de Servicios de Cosecha Dorado ganan en promedio un millón doscientos.
} 
instalaciones a través de la cual contrata a un grupo de corteros, y además tiene corteros que están contratados directamente por el ingenio. El objetivo de la fragmentación está fallando para el ingenio, porque en este caso los trabajadores reconocen que tienen el mismo puesto, hacen las mismas labores, pero sus condiciones son diferentes y están reclamando mejores condiciones laborales frente a las oficinas de relaciones industriales que son las encargadas de llevar a cabo los programas de RSE:

Sí, porque pues acá [El Centenario] están las primas de antigüedad, acá están las bonificaciones, porque esos son los beneficios de la compañía. Entonces eso se volvió que ellos quieren lo mismo que lo que tienen los directos. Que por qué no tienen y no entienden que ellos son una empresa filial más no son directamente con nosotros. Entonces si acá por lo menos vamos a cambiar la dotación, ellos también quieren que la dotación de ellos sea idéntica a la de acá, que si les hacemos un paseo que ellos también quieren y ese es el desgaste. Que entiendan que no puede ser igual porque no es la empresa directamente, pero ellos no quieren cambiar (Miriam Salazar: 4 de agosto de 2015).

No obstante, ha tenido graves desenlaces de distanciamiento entre los trabajadores que están adentro del ingenio y los que están por fuera. "Nosotros somos Centenario S.A., pero usted se imagina como padre dándole mejores condiciones a un hijo que a otro, por Dios, eso no tiene razón de ser [...] Todos somos amigos, guardando las distancias, porque ellos están en Centenario Corte”, son amigos porque son vecinos (Héctor Vaca: 16 de octubre de 2015). "De pronto a ellos las capacitaciones las hacen siempre, como le dijera, separadito, pues para no mezclar con los grupos directos" de pronto esta separación se da para evitar que se generen conflictos entre todos los corteros (Hernando Galeano: 16 de octubre de 2015).

Todas las formas de subcontratación descritas configuran lo que Basualdo y Morales (2014) llaman intermediación laboral donde el nuevo empleador, en este caso las empresas de corte, las CTA, los contratistas, entre otros solo realizan la actividad de proveer la fuerza de trabajo a la empresa principal. Asumiendo así las responsabilidades laborales con los trabajadores suministrados y cualquier conflicto que se presente entre sus trabajadores (los corteros) y la empresa beneficiaria (el ingenio). En este caso en particular el ingenio actúa como el patrón real, aunque el resto de agentes que tercerizan también controlan y supervisan el trabajo. Una de las principales razones para realizar este tipo de subcontratación es la de 
evadir responsabilidades legales frente a los derechos laborales y la capacidad de disponer de los trabajadores "just in time y con condiciones flexibles de contratación y despido" (Basualdo \& Morales 2014, 29).

\section{C.2.3. Pacto Global como respuesta a la crisis corteros-ingenios}

En el año 2010 El Dorado y en el 2011 El Centenario se adhirieron a la iniciativa de Naciones Unidas denominada Pacto Global, una iniciativa que busca alinear a las compañías asociadas para que trabajen en temas de derechos humanos, estándares laborales, medio ambientales y lucha contra la corrupción (UN Global Compact 2005). Su problema radica en que no es una iniciativa vinculante, de hecho uno de los lineamientos promovidos desde el Consejo Empresarial Mundial para el Desarrollo Sostenible es mantener la libertad empresarial a través de iniciativas voluntarias en vez de la coerción regulatoria o normativa (Banerjee 2008). En este sentido, las empresas se alían para monitorearse entre sí, lo cual impide cambios reales y de fondo (Benson \& Kirsch 2010).

La Fundación del ingenio El Centenario nació de la reorientación del tema de "lo social" después del paro del 2008. Esto pasó no solo en este ingenio, sino en toda la industria, porque decidieron organizar más las políticas de responsabilidad social, algo que se venía realizando desde el año 2000 (David Campo, director de la fundación Centenario: 11 de agosto de 2015). Esta reorientación era una necesidad, porque había un "descontento en contra de los ingenios y, en general, las personas se comenzaron a solidarizar con los corteros [...] entonces surge una necesidad en el sector por visibilizar la parte social que han venido realizando a lo largo del tiempo" (Carolina Trujillo: 30 de junio de 2015).

Por esto a partir del 2010 los programas que se hacían en el ingenio, tomaron un nuevo enfoque basado en Pacto Global, "porque antes se manejaba un concepto mucho más asistencialista [o paternalista] y lo que yo te digo la actividad, el dar, el regalar, el hacer" (Stella Galvis, jefe de relacionamiento con la comunidad: 6 de agosto de 2015). El Pacto Global marca el inicio de una nueva era de pautas de relación con los distintos grupos de interés de la empresa y una supuesta ruptura con las formas paternalistas anteriores. No obstante, como se explorará en el siguiente capítulo a pesar de los cambios, existen continuidades entre una etapa y otra. Además, existía una presión en "los mercados tanto 
nacionales como internacionales. Exigían cierta transparencia y ciertos modos de operar como condición para consumir azúcar" (Carolina Trujillo: 30 de junio de 2015).

Mira nosotros nos adherimos al Pacto Global, no me acuerdo hace cuanto si hace 3 ó 4 años. Y digamos que la razón de adherirnos es para demostrar, no a la comunidad nacional sino a la internacional, que nosotros cumplimos con todos los lineamientos globales y a nivel general en Colombia en la parte que tiene relación con el trabajo, con las normatividades laborales, con la responsabilidad social, que cumplimos con absolutamente toda la ley y un poquito más [...] Entonces como no hacemos publicidad una forma de hacer, no publicidad, si no de demostrar que cumplimos con todas las normatividades, pues lo vimos que era con el Pacto Global y nos adherimos con todo. El trabajo, la niñez, en contra de la esclavitud, de todo eso. Los famosos diez mandamientos (Alejandro Rengifo: 8 de julio de 2015).

Las empresas empezaron a hacer parte de todas aquellas iniciativas de respeto por los derechos humanos. "Porque, pues laboralmente hay unas condiciones que no se le pueden quitar al trabajador, pero lo social eso siempre sale de la voluntad del empleador hasta donde el empleador quiera dar" (Miriam Salazar: 4 de agosto de 2015). Que el carácter voluntario se promueva de manera discursiva desde el sector empresarial y que los programas sociales sean a discreción de "la voluntad del empleador" impide evaluaciones de fondo y regulaciones coercitivas por parte de los estados. Además esto implica que los beneficios que brindan las empresas se disfruten mientras la compañía quiere (Banerjee 2008; Benson et al. 2010). Una vez que estos son suspendidos, los trabajadores y distintos beneficiarios no tienen forma de reclamar por los beneficios que perdieron porque nunca fueron derechos adquiridos. En ese sentido, la sociedad civil y los trabajadores quedan expuestos a los caprichos de la empresa.

\section{C.3. Asociación colectiva o Representación}

En este subcapítulo se pretende mostrar el papel qué han jugado los sindicatos como un tercer actor activo en la relación entre los ingenios y los corteros, así como una caracterización de los sindicatos presentes en los ingenios estudiados. La época de las empresas de corte inaugura una nueva etapa de posibilidad de asociación sindical que le permite tramitar de manera legítima a los corteros ciertas demandas, a diferencia de épocas anteriores. En la época de los contratistas no podían porque corrían el riesgo de perder su trabajo y en la de 
las cooperativas tampoco era posible porque resultaba ser un sinsentido la realización de negociaciones colectivas y los pliegos de peticiones, ya que debían ser presentados y tramitados por ellos mismos puesto que eran los dueños de sus empresas.

Tabla 8 Ingenios, empresas de corte y sindicatos

\begin{tabular}{|c|c|c|c|c|}
\hline Empresa & $\begin{array}{l}\text { Sindicato } \\
\text { (Nombre } \\
\text { cambiado) } \\
\end{array}$ & Presencia & $\begin{array}{l}\text { Número de } \\
\text { afiliados en la } \\
\text { empresa }\end{array}$ & $\begin{array}{l}\text { Central } \\
\text { Sindical }\end{array}$ \\
\hline \multirow[b]{2}{*}{ El Centenario } & Sintrazúcar & $\begin{array}{l}\text { Solo está en El } \\
\text { Centenario }\end{array}$ & 1648 & CGT \\
\hline & Sintracampo & $\begin{array}{l}\text { En varias empresas } \\
\text { de la Industria } \\
\text { Agropecuaria }\end{array}$ & $\mathrm{S} / \mathrm{D}$ & CUT \\
\hline $\begin{array}{l}\text { El Centenario } \\
\text { Corte }\end{array}$ & Sintracultivos & $\begin{array}{l}\text { Está en } 9 \text { empresas } \\
\text { del sector entre } \\
\text { ingenios y empresas } \\
\text { de corte }\end{array}$ & $\mathrm{S} / \mathrm{D}$ & CUT \\
\hline \multirow[b]{2}{*}{ El Dorado } & Sintradorado & $\begin{array}{l}\text { Solo está en El } \\
\text { Dorado }\end{array}$ & 600 & CTC \\
\hline & Sintracultivos & $\begin{array}{l}\text { Está en } 9 \text { empresas } \\
\text { del sector entre } \\
\text { ingenios y empresas } \\
\text { de corte }\end{array}$ & 17 & CUT \\
\hline \multirow{2}{*}{$\begin{array}{l}\text { Servicios de } \\
\text { Cosecha } \\
\text { Dorado }\end{array}$} & Sintracaña & $\begin{array}{l}\text { Solo está en } \\
\text { Servicios de Cosecha } \\
\text { Dorado }\end{array}$ & $\mathrm{S} / \mathrm{D}$ & $\mathrm{S} / \mathrm{D}$ \\
\hline & Sintracampo & $\begin{array}{l}\text { En varias empresas } \\
\text { de la Industria } \\
\text { Agropecuaria }\end{array}$ & 358 & CUT \\
\hline
\end{tabular}

Fuente: Ministerio del trabajo y páginas web de los empresas de corte

En el cuadro anterior, se puede observar que existen cinco sindicatos en los dos ingenios del caso de estudio y sus empresas filiales de corte de caña. Tres de los sindicatos tienen presencia única y exclusivamente en una empresa: Sintrazúcar, Sintradorado y Sintracaña. Por su parte, Sintracultivos tiene presencia en otras empresas del gremio azucarero y Sintracampo tiene presencia en otras industrias asociadas al agro en diferentes regiones del país.

Sintracultivos se constituyó en 1974 como sindicato de industria asociado a la CUT. Actualmente tiene presencia en nueve de los doce ingenios, incluido El Centenario Corte y El Dorado. En principio, este sindicato resolvía los problemas desde una mirada más 
"política", que a veces generaba confrontación al momento de las negociaciones. "Polarizaba mucho más la relación entre empleadores y trabajadores y era como más evidente la confrontación, las marchas, las protestas, los mitos y todo lo que maneja el movimiento sindical" (Andrés Castro: 21 de julio de 2015). Era una época en que la relación sindicatoempresa estaba atravesada por los discursos anticomunistas de la Guerra Fría (Urrea Giraldo 2010). Y este era un sindicato que seguía los lineamientos del partido Comunista.

Existe una diferencia entre los sindicatos por rama económica con afiliados en varios ingenios y aquellos que en su nombre hacen alusión al del ingenio como Sintradorado. "Porque son sindicatos de base ${ }^{17}$, y hoy por hoy están como muy cuestionados, ya cumplieron su rol como sindicatos y lo que imperaría en el mundo es el sindicalismo de industria o por rama o actividad económica” (Andrés Castro: 21 de julio de 2015).

Sintrazúcar es el sindicato de los trabajadores de El Centenario. Para el año 1987 el sindicato estaba asociado a la CGT. "Una confederación que se alimenta del humanismo integral, del humanismo cristiano, que en su momento fue anarquista, abstencionista y hoy, por el contrario, estamos en todo, participando de la democracia, política, en todo" (José Aragón: 4 de agosto de 2015). Este sindicato, según su presidente, se diferencia de los sindicatos asociados a la CUT, porque desde su concepción cristiana era más afín y aceptada por los empresarios. Para estos, era más sencillo llegar a acuerdos entre el sindicato y la empresa (José Aragón: 4 de agosto de 2015).

Según Urrea Giraldo (2010) para la segunda mitad del siglo XX se profundizó la represión al movimiento sindical de izquierda que estaba asociado a una parte del partido Liberal y del Comunista. Pero al mismo tiempo se apoyó y promovió ampliamente al sindicalismo manejado por la iglesia y el partido Conservador. Estos últimos, promovían una fuerte disciplina obrera e intentaban evitar las huelgas a toda costa, cuando estas se presentaban, se asumía que buscaban fines oscuros asociados al comunismo (Urrea Giraldo 2010, 144).

En el caso de El Dorado, cuando se estableció el sindicato de trabajadores. Una de las primeras demandas fue establecer como obligatoria la prima que el dueño del ingenio daba

\footnotetext{
${ }^{17}$ El entrevistado nombra a Sintradorado como un sindicato de base, que en este caso, según su descripción del mismo hace referencia a un sindicato patronal.
} 
de manera voluntaria (Oscar Coronel: 24 de julio de 2015). En estas primeras épocas de instalación del sindicato en El Dorado la función de los padres de la iglesia católica fue fundamental. Pues el párroco de la empresa se encargaba del diálogo y el control de los trabajadores, específicamente del sindicato.

[La tarea del padre era hacer] ejercicios espirituales a los trabajadores y ayudaba a que los trabajadores no se desmidieran pidiendo demasiado, porque nacieron los sindicatos y los sindicatos hacían huelgas. Entonces siempre le decían que no acabaran con quien les daba la comida, que bajase porque estaba pidiendo mucho. Y no porque fueran vendidos sino porque se les indicaba a los capellanes que el pedido del sindicato era muy alto y no alcanza. Entonces ellos ayudaban a hacerle comprender (Julián Lorza: 22 de julio de 2015).

Sintracaña y Sintracampo son los sindicatos de Servicios de Cosecha Dorado. Cuando se formó esta empresa en el 2012, Sintracaña era el sindicato mayoritario con aproximadamente 400 asociados, sin embargo ha tenido dificultades con la negociación del pliego de peticiones, de hecho hasta el año 2016 no se había podido negociar. Esto generó que la mayoría de asociados se cambiaran a Sintracampo. Este nuevo sindicato "tiene mucha asesoría, tiene una asesoría mucho más amplia y entonces le facilita ser como más avanzada, fluir más en las negociaciones y como ser más eficiente en ese tema, lo que Sintracaña no ha podido" (Ernesto Lopera: 28 de diciembre de 2016). Sintracampo en el año 2015 firmó un pliego de peticiones que cobija a 358 trabajadores y tiene vigencia hasta el 2019.

Los sindicatos con la misma denominación de la empresa tienen la mayor cantidad de afiliados por empresa, en comparación con los sindicatos de industria u otro tipo de sindicatos. En el caso de El Dorado, su sindicato Sintradorado tiene 600 afiliados en comparación con los 17 de Sintracultivos (Andrés Castro: 21 de julio de 2015). Pero en cuanto a Sintradorado "la gente confunde, vio sindicatos de empresa, son de allá patronales. No, somos de una empresa. Patronales es que el patrón te escogió vaya a hacer este sindicato y fórmelo" (Jaime Salazar: 9 de julio de 2015).

Hoy por hoy una de las grandes controversias entre los sindicatos, gira en torno a una nueva normativa legal que le permite a los sindicatos minoritarios negociar con las empresas. En el caso de El Centenario, Sintrazúcar cuenta con 1648 afiliados y Sintracultivos, que es el sindicato de Centenario Corte, tiene 4 ó 5 afiliados en El Centenario, al igual que 
Sintracampo:

Entonces, si nosotros tenemos 1648 afiliados cómo nos vamos a sentar con unos señores que no están representando a nadie, 5 ó 6 personas, y que nos dicen hagamos el pliego único. Cómo así, qué intereses tienen ellos y los intereses de ellos, con toda seguridad, van en contravía de los nuestros (José Aragón: 4 de agosto de 2015).

La relación entre los sindicatos asociados a las distintas centrales es conflictiva, por tanto en ocasiones puede llegar dificultar el trámite de las demandas por mejores condiciones de trabajo y por la protección de los derechos de todos los trabajadores de la industria. De hecho, Sintrazúcar, el sindicato de los trabajadores de El Centenario, asociado a la CGT sostuvo un contrato sindical con el ingenio para la subcontratación de corteros antes del paro del 2005.

Una de las críticas que hacen los corteros a los sindicatos es que las limitaciones a ejercer el derecho a la huelga en las empresas de corte fue en parte culpa de los mismos sindicatos. Por ejemplo, la CUT a través de Sintracultivos asesoró a los corteros al momento de la negociación para levantar el paro del 2008. La primera de estas negociaciones se dio en el ingenio Azul y fue avalada por los representantes de los corteros y de los sindicatos. Luego, el modelo de contratación actual surgió de estos acuerdos y para Ernesto Lopera, supervisor de corte, que los sindicatos salgan "a criticarlo, pues no sería como lo más prudente, porque es fruto de lo que ellos mismos asesoraron y si es mala la figura actual, fue mala la asesoría que ellos brindaron en su momento" (Ernesto Lopera: 28 de diciembre de 2016).

Con el tema de los corteros hay que reconocer y de manera autocrítica que hubo una falencia de todo el movimiento sindical de las tres centrales obreras: la CUT, la CGT y la CTC que son las más importantes y que tienen presencia en el sector de la caña de azúcar. Digo en qué sentido, en que estas personas por no tener un vínculo directo con los empresarios ya que sus empleadores eran contratistas, muy poco le prestamos atención a su problemática para la forma en que eran sometidos y con condiciones laborales muy inequitativas, diría que injustas (Andrés Castro: 21 de julio de 2015).

El movimiento sindical no le dio una debida diligencia al problema de las condiciones laborales de los corteros, aunque la responsabilidad también recae sobre los empresarios 
porque no hicieron un control efectivo y responsable frente a terceros que le prestaban el servicio de corte de caña. Ya por ejemplo, durante el desarrollo del segundo paro, aunque los sindicatos enviaron representantes para intentar mediar entre los empresarios y los corteros "las posiciones fueron muy radicales, de ambas partes y llevó a que el paro tomara unas dimensiones muy serias y que tuviera pues una duración de más de 30 días en la mayoría de los ingenios" (Andrés Castro: 21 de julio de 2015).

En ese momento varias organizaciones sindicales nacionales e internacionales hicieron colectas para enviar a los corteros, con el fin de ayudar a sostener el paro. Sin embargo, de ese dinero "no vimos ni una moneda, ni un peso de esa plata de apoyo, no nos llegó nada" (León Aguirre: 4 de agosto de 2015). Algunas personas asumieron que dichas ayudas se las habían robado los líderes del paro, otros dijeron que se las habían robado los sindicatos. La única verdad, es que si efectivamente se recogió plata, esta nunca llegó a su destino final.

Hoy en día los sindicatos están acompañando a los corteros en reclamaciones que se remontan a épocas previas a los paros, según Adolfo Madrid, abogado laboralista del sector azucarero, desde hace aproximadamente cuatro años la lucha de los afiliados a la CUT, no se está dando propiamente en el corte, en los cañaduzales hay una calma aparente y se ha reflejado en una estabilidad prolongada; presionados o instigados por las unidades legislativas de algunos congresistas de izquierda, especialmente Alexander López, las reivindicaciones las han trasladado en forma de demandas ante los jueces laborales y de pequeñas causas, las que en principio prosperaron en primera instancia, pero vienen siendo revocadas por los Tribunales en Buga. “ ¡En la actualidad la lucha de los cañales se trasladó a los despachos judiciales!” (Adolfo Madrid: 27 de julio de 2017). 


\section{Capítulo 3. Responsabilidad social empresarial}

El objetivo de este capítulo es exponer cómo opera la Responsabilidad Social Empresarial (RSE), qué continuidades o rupturas existen entre esta nueva forma de relación obreropatronal y el paternalismo. Asimismo ver cómo los corteros convierten a la RSE en una arena de disputa como miembros de la comunidad ${ }^{18}$ o como proveedores. Este es un grupo de trabajadores que, como se expuso en el capítulo anterior, está fragmentado como una estrategia empresarial para dividirlos. Esto se evidencia en tanto que al mismo tiempo hay corteros directos o colaboradores y tercerizados o proveedores.

Este capítulo se compone de dos partes. La primera es una caracterización de los cambios en las relaciones obrero-patronales que se han desarrollado en los ingenios con el paso del modelo paternalista al de la relación personalizada y directa, pero subordinada a una estrategia de costos promovida desde la RSE. Para esto se hace un recuento de las continuidades y rupturas entre uno y otro, así como la relación que establece el ingenio con sus distintos grupos de interés.

En la segunda parte se realiza una exposición de la forma en que los corteros resignifican la RSE y la configuran como una arena en disputa a través de la cual logran acceder a beneficios para mejorar sus condiciones de vida y de trabajo. Esto se hace mostrando los programas a los que tienen acceso los corteros, por un lado, y exponiendo cómo al mismo tiempo que los ingenios excluyen a los corteros de las empresas a través de la subcontratación los reconocen por medio de la RSE, por el otro.

\footnotetext{
${ }^{18}$ Cursivas agregadas, porque estos no son conceptos desarrollados en la teoría sociológica sino que hacen referencia a las definiciones propias de los entrevistados.
} 


\section{D.1. Paternalismo o RSE: continuidades, rupturas, grupos de interés y productividad}

Según Miriam Salazar, jefa de bienestar social, los ingenios se unieron al Pacto Global, iniciativa de Naciones Unidas, como parte de los ajustes necesarios que realizan empresas agroindustriales para competir en el mercado internacional, donde se les exige ser responsables con el fin de ser deseables en el mercado. En un principio se habló de sostenibilidad y la gente pensaba que eso "tenía que ver con el recurso natural, no se entendía muy bien, entonces uno pensaba que era de las fundaciones o las ONG, pero no. Esa figura [de Pacto Global] fue transversal a todas las compañías y ésta no fue ajena a ella" (Miriam Salazar: 4 de agosto de 2015).

Desde que ambos ingenios hacen parte de la iniciativa de Naciones Unidas comenzaron a utilizar la metodología del Global Reporting Iniciative para el reporte anual de actividades por medio de informes de sostenibilidad asociados a las prácticas, discursos y metodologías propios de la RSE. Desde estas nuevas metodologías se reemplaza al empresario como sujeto individual por un equipo especializado "que con una lógica de cálculo opta por relaciones personalizadas y directas con los trabajadores, aunque estrictamente subordinadas a una estrategia de costos, y fuertemente vinculadas a planes productivos" (Valero 2013, 346).

Estos informes se realizan a partir de la recolección de datos cualitativos y cuantitativos que incluyen: gestión de calidad, gobierno, ambiental y social. De esta última se destaca el reporte de temas como empleo, salarios y beneficios, capacitación y evaluación, bienestar, salud y seguridad en el trabajo, derechos laborales, derechos humanos y comunidades (El Dorado 2015). En dichos informes se presenta la información junto a un plan de acción "enfocado a cuatro de los grupos de interés: los colaboradores, las familias, la comunidad y los proveedores" (Carolina Trujillo: 30 de junio de 2015. Cursivas agregadas). En palabras del gerente de El Dorado, la RSE:

No es solamente pague bien, pague lo que es, sino acompañe, colabore, extienda la mano, cuando hay que liquidar se liquida. Con los trabajadores de la compañía, con los que nos prestan servicios, con la comunidad en general, con las familias de los trabajadores nuestros, con familias de la región que no tenemos absolutamente nada que ver y también vemos a ver cómo se les colabora (Alejandro Rengifo: 8 de julio de 2015). 
En este nuevo todo se cuantifica sistemáticamente, en términos de costos y beneficios y se utilizan medios de difusión para mostrar características destacables de las compañías frente a sus trabajadores y a la opinión pública, como un componente de las prácticas de RSE. Mientras que el antiguo accionar paternalista, basado en pautas costumbristas y tradicionales permanece (Valero 2013). En este nuevo escenario de RSE a los colaboradores, o trabajadores directos de los ingenios, la empresa les brinda dádivas adicionales por medio de programas que resultan siendo un beneficio extra al salario; y en algunas ocasiones sus condiciones laborales superan lo exigido por ley.

Los trabajadores directos son especialmente considerados por los programas de RSE y en menor medida los corteros tercerizados. No obstante este segundo grupo de trabajadores canaliza hacia los programas de RSE sus demandas por mejores condiciones de vida y de trabajo. De esta forma, resignifican el rol de las dependencias dirigidas exclusivamente al trato con los proveedores y con la comunidad. Estas dependencias hacen parte de las estrategias de las empresas para desplazar el conflicto a un ámbito que les permite responder con programas que pueden quitar o poner a voluntad. Al mismo tiempo refuerzan la fragmentación del conjunto de los corteros porque desde la empresa se diferencian los tipos de beneficios “extra salariales" según sean colaboradores, proveedores, etc. No obstante, los trabajadores del corte de caña cambian el sentido de la RSE al convertirla en un espacio de disputa e incluirla en sus demandas por mejoras condiciones.

\section{D.1.1. Del paternalismo tradicional a la burocratizada RSE: las rupturas y continuidades}

El paternalismo en su concepción tradicional mostraba como "el empresario combinaba elementos ideológicos y pragmáticos inspirados en la equidad, que al mismo tiempo eran convenientes a su propio interés" los cuales generalmente se materializaban en servicios de vivienda, educación, ocio sano, pensión de invalidez, apoyo en la viudez, enfermedades o accidentes. Por medio de estos servicios el patrón "se convertía en organizador de la seguridad del obrero a quien se veía como incapaz de previsión y ahorro" (Valero 2013, 41). No obstante, la implementación del paternalismo clásico no se dio en todos los ingenios por igual, de la misma forma la RSE no se ha instalado completamente en todas las empresas. 
Esto genera una superposición de viejas y nuevas formas de asistencia social y control de la vida de los trabajadores y sus familias.

El momento de cambio en El Dorado y la instalación de la RSE comenzó con la llegada de Alejandro Rengifo quién realizó una evaluación de los programas que se desarrollaban en ese momento en el ingenio; programas de tipo filantrópico que no tuvieran un fin, ni unos destinatarios específicos no podían ser llevados a cabo (Carolina Trujillo: 30 de junio de 2015). Por su parte en El Centenario los cambios llegaron en el año 2009 cuando se realizó un diagnóstico para hacer una priorización de los grupos de interés y en ese momento se estableció que para cada grupo, habría un área encargada de su atención y todas estaban bajo la sombrilla del área de Relaciones Industriales (Stella Galvis: 6 de agosto de 2015. Cursivas agregadas).

Era una combinación entre lo social, internamente, nuestro cliente interno que es el trabajador y también externo para poder tener un manejo de las relaciones públicas externas de la compañía. Entonces en ese orden de ideas, la compañía decide escoger unos departamentos, puntualmente, bienestar social, que es el que yo dirijo, y en sus planes de acción colocar el tema de la sostenibilidad. Era poder, esto que teníamos acá, internamente, sacarlo a la luz de la comunidad que no [lo] conocía (Miriam Salazar: 4 de agosto de 2015. Cursiva agregada).

Antes, el antiguo paternalismo era manejado por personas caritativas, las ayudas se daban por "altruismo", los dueños o sus familiares manejaban las relaciones de manera personal y a partir de experiencias empíricas. Hoy es manejado por profesionales a través de vínculos impersonales regidos por normas, reglamentos e indicadores. En términos de Valero (2013) cambió el tipo de personas que gestionan la relación de la empresa con los trabajadores, sus familias y la comunidad. En palabras de una de estas profesionales, antes:

[...] el corazón de una dama que sentía que humanamente había que hacer caridad con los demás, porque si yo tengo, yo comparto con los demás. Era netamente altruista, Pero pues, ya la gente que está a cargo de estos puestos, pues tienen una formación y saben que las cosas no se hacen por hacerse, si no que tiene que 
haber un impacto y por eso se siguen haciendo (Miriam Salazar: 4 de agosto de 2015).

Antes las cosas se hacían por altruismo, regalar por regalar y era decidido desde arriba hacia abajo. En ese sentido, Stella Galvis cuenta que antes de la reestructuración "lo que hacían las áreas que trabajaban [con la] comunidad era festejar el día de Halloween ¿sí o no?, dar regalos en Navidad [...] No, ese no es nuestro criterio, nosotros intentamos que nuestros programas sean procesos que generan capacidades" (Stella Galvis: 6 de agosto de 2015). Es decir, según las personas entrevistadas hoy los programas se organizan a partir de objetivos, relacionados con la producción en términos de impacto y además buscan involucrar activamente a los beneficiarios. Los ingenios buscan que su efecto no esté enfocado en "regalar por regalar, es porque ya se ha hecho un estudio, es porque ya sabemos que vamos a impactar no a una [persona], sino a una comunidad" (Miriam Salazar: 4 de agosto de 2015. Cursivas agregadas). A diferencia de lo que sucedía en las fiestas descritas donde se hacían diferentes actividades que no respondían necesariamente a temas productivos, como lo describe Humberto Sánchez:

Hace unos 27 años las empresas tanto El Centenario, como otras, [... no daban] unos auxilios, sino unos regalos a los trabajadores, entonces nosotros teníamos la idea de que eso era muy bueno. El Centenario llegó a dar hasta carros para los trabajadores en las fiestas que hace en diciembre [...] de despedida para todos sus colaboradores, entonces digamos que de un tiempo para acá ha cambiado. [...] ¿En qué sentido?, ya no volvieron a rifar carros, ya no volvieron a dar esas comidas tan grandotas, por qué, porque yo fui uno de los que digamos me arrepentí y me arrepiento de haber cogido, por ejemplo, la comida y haberla dejado por allá tirada (Humberto Sánchez: 16 de octubre de 2015. Cursivas agregadas).

Antes se otorgaban beneficios de manera indiscriminada, hoy se distingue a partir del tipo de vinculación con la empresa. Hay un cambio de vocabulario pero se identifican confusiones con los viejos términos. La instalación del área de relaciones industriales marca una transición del viejo orden tradicional al nuevo orden tecnocrático de configuración de las organizaciones. Dichos cambios obedecen a lógicas de productividad, ordenamiento de la 
organización y control de la fuerza laboral. En el caso analizado por Valero (2013) la reestructuración tenía el propósito de "asumir una relación más directa con los empleados, evitando el protagonismo del sindicato, como dispensador de beneficios arrancados a la empresa; la gerencia procuraba mostrarse como el principal ente promotor de mejoras, destinada a satisfacer sus expectativas". En el marco de estos cambios se establecen programas con las familias, vivienda y educación.

Se evidencia una superposición entre el antiguo paternalismo y la nueva RSE en términos de prácticas similares y sobretodo en la permanencia de la forma de nombrar a los trabajadores directos, pues aún hoy no está naturalizado el uso de la palabra colaborador para nombrar a este grupo de trabajadores. De hecho, la directora del área de bienestar social continúa llamándolos trabajadores y no colaboradores como se establece desde la RSE. Aun no se internalizan por completo los lineamientos estrictos y burocratizados en los ingenios, por el contrario, quedan vestigios de prácticas paternalistas instaladas en los mismos que son difíciles de cambiar.

Antes en la relación ingenio - comunidades vecinas el ingenio cumplía el rol de suplir al estado como lo afirman Alejandro Rengifo y David Campo. No obstante, hoy en día El Dorado, por ejemplo, busca que al trabajar con las comunidades aledañas al ingenio todo el mundo ponga algo: "la comunidad pone la mano de obra, nosotros colocamos materiales [...] la relación funcionó: que era comunidad-ingenio, no, papá ingenio deme, que así era antes” (Alejandro Rengifo: 8 de julio de 2015). Para los administradores del ingenio, si la gente que vive alrededor del ingenio está bien se previene que haya "malandros. Se ha mantenido así porque se les atiende, prestándoles servicio, limpiando las carreteras, dándoles para que arranquen, repartiendo azúcar para que la gente esté bien y contratando a los hijos en el ingenio" (Julián Lorza: 22 de julio de 2015. Cursivas agregadas).

Anteriormente no se presentaban los resultados de los programas realizados, hoy en cambio se hace de manera sistemática, anualmente y siguiendo protocolos de presentación del Global Reporting Initiave (GRI) y el Pacto Global así como el uso de la publicidad como herramienta fundamental de la RSE. No obstante no todo se presenta en dichos en informes. "Es que no todo es material. Muchas cosas son de apoyo moral o apoyo cívico. Pero si hay bienestar en la región, la empresa está bien” (Alejandro Rengifo: 8 de julio de 2015). El 
Dorado, brinda cierto tipo de apoyo que excede la planificación de los programas de RSE y su reporte en los informes de sostenibilidad. En este caso según el gerente la idea es que las comunidades que están en los territorios que rodean los ingenios no vean a la empresa como un enemigo. "Todo eso es rentabilidad. Eso es jugar al gana-gana. Si la gente está bien, uno está bien. Y eso no significa que los dejés hacer lo que se les dé la gana” (Alejandro Rengifo: 8 de julio de 2015).

Esto mismo sucede con la comunidad, hay muchas acciones que se llevan a cabo que no quedan registradas de manera sistemática, ni están siendo evaluadas a partir de indicadores como los programas oficiales de los ingenios. "La gente ve al ingenio como mi único salvador [...] Qué pensará, ¿que aquí se soluciona todo? y aquí te traen servicios públicos, aquí se traen hijos que no han conseguido empleo, aquí que los hijos quieren estudiar, todo, todo" (Miriam Salazar: 4 de agosto de 2015). En El Dorado por ejemplo, "yo he regalado sillas de ruedas y camas para enfermos, a gente que no tiene absolutamente nada que ver con los ingenios, pero lo hacemos súper callados la boca, porque si no te llegan 20 peticiones más y todas graves" (Alejandro Rengifo: 8 de julio de 2015). Un ejemplo de esto fue la carta de una niña que vive en los alrededores de El Dorado, dirigida al gerente donde le pedía una cama:

Se fueron y llegaron allá sin avisar y qué fue lo que nos motivó, que la niña estaba muy aseada, no era sucia, no era mal criada, no era mal llevada, era una niña supremamente aseada en unas condiciones de pobreza tenaces, pero llama la atención que la mamá preocupada por la niña cuando vos ves otros sitios que tienen mejores modos y los niños son sucios. Y por eso le regalamos la cama con todos los juguetes, colchón con todos los juguetes [...] Pero nos quedamos callados, bien ah eso es muy verraco, porque eso es un límite que no existe. Existe en tu cabeza. Pero si ves esa ayuda de la niña es una vaina que favorece a la compañía porque la gente va a hablar de la compañía, pero nosotros no hablamos de eso [...] De eso no decimos nada, porque eso puede ser usado en tu contra por el abuso de la gente. La gente abusa [... Esto] lo hacemos por voluntad propia. Pero eso al final si es RSE (Alejandro Rengifo: 8 de julio de 2015).

"Si vos ves los informes que nosotros presentamos son limitados a la comunidad en general y a los trabajadores en general, pero no al trabajador específico, ni a la ayuda específica. Esa no la nombramos, no decimos nada" (Alejandro Rengifo: 8 de julio de 2015). 
Es decir, el antiguo paternalismo se superpone con las nuevas prácticas de RSE. En El Centenario son mucho más estrictos al momento de implementar los protocolos y las normas, porque esperan que sus acciones impacten a más de una familia.

Por ejemplo "arreglarle la casa a la familia Pérez [... que] está en malas condiciones ahí si no podemos intervenir. Porque nuestra intervención es comunitaria" (Stella Galvis: 6 de agosto de 2015). Según Stella sí se hacen acciones dirigidas a personas específicas se pueden generar conflictos para el ingenio, así no se publique en documentos, ni se difunda en medios de comunicación, el voz a voz en la comunidad es muy fuerte. Para prevenir estos conflictos, se busca que los programas "beneficien al grupo poblacional determinado, no para personas y puede sonar duro, puede sonar indolente, pero es muy serio" (Stella Galvis: 6 de agosto de 2015).

No obstante, no todo lo que no se registra en los informes se justifica por la necesidad de impactar a muchas personas y no a una sola familia o porque se sale de los objetivos específicos de uno u otro programa. De hecho, en ocasiones se deja por fuera información que puede afectar la empresa, como las enfermedades ocasionadas por el trabajo. En El Centenario, según Miriam Salazar, estos informes no contienen la información de "cuánta gente usted ha atendido esta semana con problemas de manguito rotador ${ }^{19}$ en el corte de caña, no pues pueden ser alrededor de unos 50 ó 60, pero uno no los reporta, porque es el día a día” (Miriam Salazar: 4 de agosto de 2015). Reportar estas cifras de manera sistemática y organizada sería aceptar que el trabajo en el ingenio causa problemas de salud.

Antes con las relaciones personalizadas de dueños, sus familiares o gerentes del ingenio los trabajadores podían acercarse a sus oficinas a pedir ayuda en determinadas situaciones. Situación similar sucede hoy en día con los trabajadores pues ellos buscan al ingenio para

\footnotetext{
${ }^{19}$ Según la ARL Sura (2017), el manguito rotador "es un conjunto de músculos y tendones que están ubicados en medio de los dos huesos más grandes que tiene el hombro, sosteniendo toda esta parte del cuerpo y permitiéndonos hacer movimientos como estirar, doblar o mover los brazos, sin que se desencajen los hombros". El manguito rotador se enferma "literalmente por el uso y el abuso".

Aleyda Patricia Chacón, abogada laboralista, al respecto afirma que en ocasiones los movimientos repetitivos asociados a algún trabajo con una alta carga física pueden terminar en lesiones del manguito rotador. No obstante este tipo de enfermedades laborales no siempre se les da el reconocimiento debido ni por medio de la EPS ni de la ARL (El País 2014). Esto es problemático en un escenario donde son atendidos entre 50 y 60 trabajadores por semana.
} 
que los apoye y en ocasiones les ayude a solucionar problemas que exceden los vínculos laborales, estrictamente hablando. Esto es una evidencia de que las prácticas paternalistas donde priman las relaciones personalizadas, con vínculos directos definidos por la costumbre y al arbitrio de los empleados asociados a las áreas de relaciones industriales aún existen en la práctica y en el día a día.

Miriam Salazar cuenta que en el desarrollo normal de su trabajo un trabajador le dice a uno "mire doctora es que a mí, la cita me la dieron para dentro de seis meses y esto es urgente" [...] "no, el copago no me da" y entonces préstenos para la cirugía" (Miriam Salazar: 4 de agosto de 2015). Ella explica que esto está justificado desde los programas de RSE porque se busca promover un buen ambiente laboral y que los trabajadores se sientan bien. Esto muestra como por un lado hay programas dirigidos a los trabajadores directos que se miden, se controlan, se reportan al mismo tiempo que se sigue ayudando a cada uno por separado cuando la ocasión lo amerita. "Porque lo social que haga la empresa impacta al trabajador directamente" (Jaime Salazar: 9 de julio de 2015).

Trabajadores directos de El Centenario narran que, "si tiene problemas con su señora, la doctora le colabora a uno, y [...] cuando hay problemas en el trabajo uno le pregunta a ella y ella le colabora a uno. Ella es una persona muy cordial con uno" (Francisco Castro: 16 de octubre de 2015). En ocasiones le ayudan, hasta a quienes no están contratados directamente por el ingenio. Estas dádivas a discreción de los encargados de las áreas de Relaciones Industriales, se extiende incluso a trabajadores indirectos o tercerizados, y esto también está por fuera de los informes y del accionar que se reporta anualmente.

"La doctora la otra vez le prestó a un pelado de Adecco yo vi cuando le dio el dinero al pelado, o sea que si les solucionan algún problema aquí no son egoístas aquí se portan bien" (Esteban Salazar: 16 de octubre de 2015). Esto demuestra que a pesar de todas las medidas adoptadas con las instalación de las áreas de Relaciones Industriales desde donde se aboga por unas relaciones impersonales, regidas por normas y reglamentos se siguen presentando relaciones personalizadas y al "arbitrio personal de los jefes" (Valero 2013) incluso en una época donde, supuestamente, todas las actividades que realiza la empresa quedan registradas por medio de los informes anuales de sostenibilidad. 
El problema es que por un lado desde la RSE se refuerza la fragmentación del conjunto de trabajadores y por el otro da beneficios que no constituyen un derecho de los trabajadores directos ni tercerizados. Puesto que constituyen prerrogativas que la empresa da pero que no están atadas a negociaciones con los sindicatos o respaldadas por pactos colectivos, por lo tanto no representan un derecho adquirido por los trabajadores, entonces no hay derecho de reclamar legalmente cuando el ingenio decida retirarla (Valero 2013).

Estamos hasta la coronilla de eso, eso se vuelve abuso. Desafortunadamente, pero más sano para donde. Porque vos a veces querés ayudar, pero la ayuda te la revierten. Vos trabajás en la compañía y no te cobró los almuerzos y te liquidaron, $\mathrm{y}$ te echaron lo que sea, entonces vos demandás y finalmente en la demanda te ponen que la liquidación está mal hecha porque no te incluyeron el valor de los almuerzos que la compañía te daba. De esas demandas nos han llegado. ¿Vos le volvés a dar almuerzo a alguien? Yo no. Pague su almuerzo. Si ves vos decís ay pero eso es ridículo, pero multiplicá un almuerzo por diez años. Entonces vos decís pues que cada quien traiga su almuercito. Son vainas absurdas (Alejandro Rengifo: 8 de julio de 2015).

Esto está asociado a lo que Subhabrata Banerjee (2008) explica, que se promueven las condiciones para que se mantenga la preferencia de los empresarios de libertad empresarial a través de iniciativas voluntarias en vez de la coerción regulatoria o normativa. Dichas prácticas producen una ilusión de transparencia puesta en escena a través del performance y las prácticas coreográficas que evidencian tanto como ocultan. Esto se logra mostrando sus corporaciones como sostenibles o responsables con el fin de evadir controles regulatorios desde el estado. Para el caso de los ingenios de caña de azúcar, los programas de RSE canalizan las demandas de los corteros a través de programas dirigidos a sus grupos de interés en este caso a la sociedad civil hacia un nuevo escenario en la cual, el estado en sus distintas ramas y niveles no interviene. Así la sociedad civil y los trabajadores quedan expuestos a los caprichos de la empresa. 


\section{D.1.2. Los efectos adversos que dejan las distintas formas de relación entre el ingenio y sus grupos de interés}

Las definiciones que se muestran a continuación evidencian que desde las áreas asociadas a la RSE se tiene claro que los programas de RSE deben facilitar a la compañía la generación de ingresos. Asimismo, quienes manejan las áreas de RSE tienen definidas las diferencias y los límites entre el grupo de trabajadores directos, los tercerizados y la comunidad. Esto refuerza la fragmentación del grupo de corteros, sobre todo de aquellos trabajadores que están contratados por medio de las empresas de corte.

En ese sentido, desde la nueva lógica de RSE se plantean programas dirigidos a la gestión de cada grupo de interés ${ }^{20}$ de manera diferenciada. No solo se dividen los programas para cada grupo, sino que también se abren espacios dentro de las empresas dirigidos a cada uno, con sus propios programas y canales de comunicación. Según el informe anual de sostenibilidad de El Dorado (2015) “son considerados grupos de interés todos aquellos que se involucran o impactan los diferentes procesos de la empresa o son impactados por las acciones de esta. En este se incluye a los colaboradores, familia de colaboradores, proveedores, accionistas, clientes, comunidad, sindicato, gremios, gobierno, comunidad y medio ambiente" (23). Para El Centenario en cambio solo hacen parte de sus grupos de interés: los accionistas, colaboradores, clientes, comunidad y proveedores.

Según el Informe de Sostenibilidad El Dorado (2015) los colaboradores son aquellos con un contrato laboral directo que configura una relación laboral regulada por el código sustantivo del trabajo. Los proveedores son "personas naturales o jurídicas que abastecen al ingenio con materia prima, productos o servicios necesarios para el funcionamiento del mismo" (Informe de sostenibilidad El Dorado 2015, 22). Los accionistas son personas naturales o jurídicas que tienen al menos una acción en la empresa. Los clientes son organizaciones nacionales o internacionales que realizan alguna transacción comercial con el ingenio por un producto o un servicio a cambio de una contraprestación. La comunidad se define como los "grupos de personas y entornos del área de influencia con las cuales la organización se interrelaciona y frente a los cuales genera impactos y oportunidades" (Informe de sostenibilidad El Dorado 2015, 22). Por último, el sindicato es la asociación o

\footnotetext{
${ }^{20}$ Cursivas utilizadas para marcar el lenguaje utilizado desde la RSE
} 
asociaciones internas y externas que representan "ante la empresa, los intereses de los colaboradores" (Informe de sostenibilidad El Dorado 2015, 23).

Ahora bien, las entrevistas a los empleados de las áreas de relaciones industriales evidencian que los programas de RSE le permiten a las compañías generar ingresos, al mismo tiempo que les demuestran a las comunidades que están cumpliendo con estándares de cuidado ambiental, social y económico. "Entonces desde esta perspectiva se considera, tiene que ser la sostenibilidad, o sea lo económico, lo ambiental la estrategia para que la empresa opere, funcione y sea exitosa" (Stella Galvis: 6 de agosto de 2015). "Acá en el ingenio el programa con las familias de los trabajadores es muy interesante porque al invertir en el bienestar de los trabajadores estos se vuelven más productivos. Que es lo que al final le importa a la compañía" (David Campo: 11 de agosto de 2015). El bienestar de las parejas de los trabajadores y en general el bienestar de la familia es fundamental para que el trabajador directo esté bien, y así sea más productivo para el ingenio.

La productividad, según David Campo, se mide en términos de disminución de ausentismo laboral, menor consumo de alcohol y/o sustancias psicoactivas. Y dado que los trabajadores, en su mayoría tienen familias, el ingenio le apunta a lo que Miriam Salazar llama el "efecto multiplicador", donde con poco dinero por trabajador se impacta a toda su familia. “¿Usted hizo esto con 2.000.000, con 3.000.000? ¿A cómo le sale cada persona?, porque así es que se dan los indicadores: lo que invierto versus lo que gano. Entonces, pienso yo, que los recursos son muy bien utilizados” (Miriam Salazar: 4 de agosto de 2015). Por ejemplo este programa dirigido a los colaboradores:

A ver yo tengo un programa que se llama La empresa en tu casa. [...] Un programa que yo creé hace un año, es esta casita [...] Entonces en esta casa hice un contenido que si tú lo abres acá vas a encontrar unas tarjetas, 36 tarjetas encuentras, con una enseñanza y atrás con una tarea. Entonces si yo llego a tu casa y veo que no tienes hijos y que solo eres tu esposo y tú, entonces yo saco la tarjeta verde que habla de la pareja. Entonces aquí dice, ejemplo, "ambos miembros de la pareja deben aprender a ser tolerantes, respetuosos y pacientes entre sí". Entonces cuál es la tarea, "si queremos vivir felices en pareja hay que empezar por aceptar al otro con sus debilidades y fortalezas" [...] Yo hago una plantilla que levanto una información [...] les digo tu qué consideras que cuál es el problema que tienen ustedes acá, "que él no me deja salir, porque es muy celoso". Entonces, inmediatamente, yo hago una intervención en lo que es el 
manejo de la confianza [...] y adicional refuerzo con sentido de pertenencia en la empresa (Miriam Salazar: 4 de agosto de 2015).

Otro programa se llama La Fuerza del Hogar dirigido a los colaboradores y sus parejas. “Allí salían temas de maltrato, de cómo se conformaba la familia, de cómo se conformaba una pareja, los pros y los contras de tener pareja, los errores que hacemos cuando nos casamos [...] se puede ir minimizando mucho el maltrato" (Miriam Salazar: 4 de agosto de 2015). De esta forma no se atendía uno a uno, sino que a través de un programa, la empresa empezó a atender problemas de familia que eran comunes en todos los trabajadores. Esto es otro ejemplo de cómo el bienestar del trabajador y el de su pareja es fundamental para el beneficio de la empresa. Además, porque así no tienen que lidiar con problemas de violencia intrafamiliar, que Miriam afirma, eran tan comunes cuando empezó a trabajar en El Centenario. Francisco Castro, un operador de tractomula, opina del programa la Fuerza del Hogar:

[...] Hasta lo hacen llorar a uno. Pues la doctora le preguntó a mi señora: ¿qué es lo que más anhela usted? y entonces ella salió al frente y dijo: casarme con él. Entonces ella le preguntó por qué y ella le contó por qué y ahí mejor dicho todo el mundo salió llorando, porque cada cual salía a contar su historia, entonces ya la doctora dijo que de las historias que había contado ella iba a escoger las tres mejores (Francisco Castro: 16 de octubre de 2015).

En El Dorado los programas de RSE dirigidos a los colaboradores están enfocados en la celebración de los días importantes. Y se implementa desde la reestructuración de los programas con la llegada de Alejandro Rengifo y busca que los trabajadores directos se sientan motivados.

Celebramos el día del padre con un $m u g^{21}$ o con un pastel o el día de la madre se hacen reuniones con todas las mamás y se les da un detalle y se les da un concierto. $\mathrm{O}$ sea son celebraciones que hacemos, no gigantescas, pero si con las mamás y algo muy bonito de vea nos acordamos de ustedes, los tenemos presentes. Con las trabajadoras mujeres y con las esposas de los trabajadores. Porque el ingenio tiene un porcentaje de mujeres altísimo. Este es el único

\footnotetext{
${ }^{21}$ Pocillo o taza, en español.
} 
ingenio que tiene gerente financiero y gerente comercial mujer ${ }^{22}$. Los demás ingenios todos son hombres (Alejandro Rengifo: 8 de julio de 2015).

Sin embargo, como señalan Banerjee (2008) y Benson et al. (2010), una vez que estos beneficios son suspendidos, los trabajadores y distintos beneficiarios no tienen forma de reclamar por los derechos que perdieron, puesto que nunca fueron derechos adquiridos solo dádivas que entregaban los ingenios siguiendo un plan específico de productividad. Además, siguiendo a Sydow (2016), los tecnicismos con los que se definen los beneficios y programas de la RSE oculta la dimensión política de estas decisiones, y por lo tanto la posibilidad de reclamar los derechos perdidos. Así, en el momento en que las agendas del ingenio cambien los beneficios se pierden. Estos beneficios hacen parte de programas que se implementan desde las empresas donde se calcula todo desde la RSE. Esa es una de las características más importantes de la RSE los beneficios se disfrutan mientras la compañía quiere.

Liberalidad es a criterio de nuestro ordenador de gastos. O sea si a mí, mi ordenador de gastos me dice este programa deportivo quítelo, o sea eso no le da para demanda [por parte del trabajador] ni nada, porque es el criterio de él. Pero mi papel es poderle decir a él: doctor eso debemos hacerlo, porque nos arroja esto, esto, esto y esto y permitir que el departamento que yo dirijo siempre esté allí presente en la recordación del trabajador, porque a veces es como cuando uno tiene una relación que la tiene allí y está contenta, pero vaya y que le quiten el novio a ver usted cómo se pone (Miriam Salazar: 4 de agosto de 2015).

Carolina, trabajadora social de El Dorado, afirma que no es una contradicción el tema de la productividad y el de la inversión en sus grupos de interés es "una relación win-win ${ }^{23}$ en la cual, por ejemplo, el ingenio debe asumir menos gastos en seguridad" (Carolina Trujillo: 30 de junio de 2015). Porque la filosofía de los dueños de El Dorado, donde dos familias son dueñas del $76 \%$ del ingenio, es que "hay que colaborarle a la comunidad, pero pues el ingenio tiene que ser rentable [...] Yo tengo que mejorar la producción para poder

\footnotetext{
${ }^{22}$ A diferencia de la opinión expresada por el gerente de El Dorado en la entrevista, para el año 2015, según el informe de sostenibilidad, en este ingenio trabajaban 58 mujeres de 706 trabajadores en total, es decir, el 8,2\%. Para el año 2015, en El Centenario el 9,5\% eran mujeres, 171 de 1832 trabajadores en total.

${ }^{23}$ Relación gana-gana
} 
hacer una casa o no [...] La comunidad puede estar bien y la rentabilidad de la compañía es negativa" (Alejandro Rengifo: 8 de julio de 2015). Y al igual que en los programas dirigidos a los trabajadores directos e indirectos continúan siendo iniciativas voluntarias con todo lo que esto significa:

El mejor exponente de la RSE en Colombia es Luis Carlos Sarmiento Angulo. Él dijo una vez que lo que la empresa tiene que hacer es generar rentabilidad para los accionistas y empleo, al mismo tiempo que minimizo el impacto de mis operaciones. Porque quiero hacerlo. Y así su marca se volvió deseable para el mercado que es lo que al final importa. Porque si usted no es sostenible o responsable está quedando por fuera del mercado (David Campo: 11 de agosto de 2015).

La RSE refuerza la fragmentación entre trabajadores directos e indirectos lograda por medio de distintas modalidades y/o formas de contratación. En cuanto a los trabajadores directos en El Centenario se ha mantenido el colegio del cual se hizo referencia en el capítulo anterior y que está asociado a un proceso civilizatorio que comenzó en las épocas clásicas de paternalismo y que continua hoy como uno de los programas dirigido a los hijos de los colaboradores del ingenio. En este colegio existen diferentes categorías para el cobro de la matrícula (Stella Galvis: 6 de agosto de 2015). En el caso de Francisco, él paga por la mensualidad de su hijo 24 mil pesos (Francisco Castro: 16 de octubre de 2015).

Los hijos de Humberto han estudiado todos en el colegio de la empresa y hoy en día su hija es ingeniera agrónoma y está haciendo la pasantía en el ingenio. Él espera que su hija sea contratada por el ingenio, "sí, a mí en ese proceso me fue bien con el ingenio, yo estoy convencido de que Centenario también continúe con ella. Que es una exalumna del colegio. Entonces estoy confiado de que sí, cuando termine sus pasantías" (Humberto Sánchez: 16 de octubre). Como los hijos de Humberto, de los cuatro hijos que tiene Hernando, tres de ellos trabajan en El Centenario uno en la fábrica, el otro en el colegio y el último en cosecha (Hernando Galeano: 16 de octubre). El hijo de Héctor asiste a la escuela de fútbol dos veces por semana y su esposa ha hecho tres cursos brindados por el ingenio (Héctor Vaca: 16 de 
octubre). Los programas de RSE dirigidos a los trabajadores directos y a sus familias representan un beneficio adicional a su salario.

En el tema de los proveedores El Centenario existe el área de suministros, la cual se encarga del seguimiento y verificación del estado de sus cadenas de suministro. Allí se encargan "de identificación, de comisiones, de cómo están los proveedores, las certificaciones que tienen y están pendientes" (Stella Galvis: 6 de agosto de 2015). Hay específicamente "un área de atención a corteros, que pues como su nombre lo indica, tiene digamos el contacto con la empresa que se creó que es El Centenario Corte y con los corteros internos que hay en la empresa" (Stella Galvis: 6 de agosto de 2015).

Un antiguo trabajador del ingenio El Dorado que hoy es contratista, afirma que a través de los programas de RSE "hasta los corteros los sacaron bachilleres" (Henry Parra: 10 de julio de 2015). Esto nuevamente, remite al tema de la construcción de narrativas de otredad basadas en imaginaros de raza y clase. Pero esta vez atados a los programas de RSE donde, como en la época clásica paternalista, justifican la intervención en términos educativos de esta población, porque son leídos como analfabetas y necesitan de los programas y la guía de los ingenios en su vida.

En ese sentido, la RSE se proyecta como incluyente, pero en la práctica es excluyente, puesto que privilegia a ciertos actores, agendas e intereses mientras margina a otros (Dolan y Rajak, 2016, 18). Y esto no solo sucede con los corteros que son el grupo de proveedores de mano de obra más representativos sino con otras personas que trabajan en el ingenio como contratistas como es el caso de Adecco. De hecho como lo narra Mario Riveros las relaciones entre distintos trabajadores del ingenio con status laborales diferentes deja en evidencia las conflictividades al interior del ingenio:

Yo pienso que más que todo, $[. .$.$] no es lo mismo trabajar con contratista que una$ persona completa, nosotros somos personas que nos metimos a la empresa, somos de El Centenario. Nosotros es la forma y actividad de nosotros y no un contrato porque es diferente, porque nos manda otra persona una constancia y entonces ellos uno no puede entrar a chocar con ellos en una cosa [...] porque lo que ellos tenían era un conocimiento básico era de bajo perfil [...] Nosotros 
manejamos normas en la empresa que son de nosotros, los contratistas manejan normas que son ellos aparte [...] hay contratistas que uno lo que hace es que él quien manda, él que los dirige a ellos. El Centenario tiene algo de que le pueden decir y ellos acceden a eso, yo no puedo tocar con una persona así perfil [...] Porque nosotros o sea cada uno es por su propia parte no (Mario Riveros: 16 de octubre).

Estos trabajadores están sujetos a un doble patrón (Basualdo \& Morales 2014) uno continúa siendo el ingenio y otro quien los contrata directamente. A lo anterior, Mario Riveros añade:

Integraciones que es la de año, es una en diciembre, entonces se les manda a esos eventos pero había un choque cuando la gente se encontraba allá [...] Qué forma es como decir él es contratista y yo soy de la empresa, vos sos una mujer acomodada y él es un muchacho que no es acomodado y la está molestando y ahí otro que sí es acomodado entonces ahí lo que va haber es bulla porque tiene que ser acomodado, esas son cosas que pasaban [...] Si, o sea en ciertas partes con nosotros teníamos como diferencias y es un choque con gente así yo digo que nosotros somos iguales, no tenemos porque la otra persona venga a menospreciarnos esa es un arma que siempre he manejado, pues porque convive mucho con ellos, entonces yo digo que hay personas iguales que uno (Mario Riveros: 16 de octubre).

Además de la preocupación por el entorno del ingenio y la productividad asociado a la ganancia de los accionistas, hay un programa en particular del ingenio El Centenario dirigido a los líderes comunitarios de las comunidades aledañas a sus terrenos que merece especial atención porque puede ser visto como una forma de cooptación de los liderazgos sociales (Benson y Kirsch 2010). Puesto que el reclutamiento de los líderes sociales es una de las tres fases ${ }^{24}$ que adoptan las empresas al atravesar por una crisis. El objetivo de esta medida es lograr que los líderes sociales hagan parte de la compañía o que a través de sus

\footnotetext{
${ }^{24}$ La primera fase es la negación la cual lleva a no responder públicamente a las críticas que en muchas lo cual en muchas ocasiones genera confusiones que terminan en un ambiente de resignación que a su vez es utilizado por las empresas para frenar la crítica (Benson y Kirsh 2010,464). La fase dos de respuesta a las críticas es cuando la compañía acepta que es cierto, que están causando algún daño, sin embargo en esta fase se hacen compensaciones sobre todo simbólicas como una forma de evitar pagar el costo completo del daño causado, pero menguando la crisis. La tercera fase, da respuesta a las críticas es cuando hay una amenaza de una crisis irreversible como bancarrota, colapso o perdida de legitimidad ante la comunidad, es ahí cuando las compañías se ven obligadas tomar medidas drásticas las cuales pueden ir variando según cada caso particular.
} 
programas puedan cooptarlos para así frenar sus críticas (Benson y otros, 2010, 466).

En el informe de Sostenibilidad de El Centenario (2015) se explica que el propósito de este programa es formar a líderes comunitarios (dignatarios de Juntas de Acción Comunal, asociaciones, fundaciones, consejos comunitarios y grupos de adultos mayores) de su zona de influencia (municipios del departamento del Cauca y del Valle) "para que promuevan el desarrollo social y económico de sus comunidades y fortalezcan la relación con la empresa" 25 (Informe de Sostenibilidad El Centenario 2015, 97). El Colegio de Liderazgos es descrito por uno de los líderes, como un espacio donde "nos enseñan asuntos públicos, formulación de proyectos, excelente, muy bueno, nos enseñan hasta Marketing político" (León Aguirre: 4 de agosto de 2015). Este Colegio de liderazgos está dividido en dos niveles por semestre:

Uno que es el componente personal el de digamos competencias personales, entonces es cómo yo me comunico como líder, cómo resuelvo los conflictos, cómo hago mediación, cómo trabajo en equipo, etcétera tenemos esos cinco grandes temas repartidos en varias opciones competencias de liderazgo, habilidades de comunicación, trabajo en equipo y mediaciones comunicativas. Y tenemos lo que ya es el asunto público manejamos tres ejes: estado social de derecho, participación ciudadanía y desarrollo [...] ¿Qué buscamos? Empoderar a estos sujetos, enseñarles, orientarlos, darles las herramientas, cómo funciona el estado todo [...] el tema del estado, cómo son los mecanismos de participación, el desarrollo local, cómo ellos tienen que empoderarse para poder ser" (Stella Galvis: 6 de agosto de 2015).

El acceso a este Colegio de liderazgo se hace a través de la invitación por parte del ingenio, incluso para continuar en el curso cada semestre el ingenio debe aprobar la entrada de los líderes. "¿A quién invitamos a repetir? Al que hace las tareas, al que asiste, al que participa. Por eso es que nosotros llevamos estadísticas de todo, llevamos indicadores [...] a quién volvemos a invitar y a quién no" (Stella Galvis: 6 de agosto de 2015).

A través de estas dinámicas asociadas a la RSE las empresas refuerzan la fragmentación del grupo de trabajadores (directos vs. tercerizados), además deciden mostrar y ocultar ciertos datos de sus informes de sostenibilidad que van acorde a sus cálculos de costo beneficio; es

\footnotetext{
${ }^{25}$ Según este informe en el año 2015 se capacitaron 116 personas y el total de inversión fue de 69 millones 500 mil pesos (Informe de Sostenibilidad El Centenario 2015, 97).
} 
decir se subordinan los programas de bienestar de los grupos de interés a la productividad de las empresas. Estos cálculos se hacen a través de protocolos y personas especializadas en estas áreas, que a pesar de regirse bajo estándares y lineamientos, continúan propiciando un trato personalizado con sus grupos de interés.

Los principios del GRI, utilizados por ambos ingenios para el reporte de sus actividades, abogan por un trato especializado a través de indicadores y protocolos establecidos y aceptados por empresas de todo el mundo. Desde el GRI se propone la divulgación de información como una forma de "ayudar a identificar y gestionar riesgos" (GRI 2017). Esta identificación y gestión pretende proteger el medio ambiente y mejorar la sociedad, mientras que al mismo tiempo le dan la oportunidad a las empresas de prosperar económicamente, mejorar la gobernanza y la relación con sus grupos de interés, optimizar su reputación y generar confianza (GRI 2017).

No obstante, en este caso en particular se observa que el sello del GRI y del Pacto Global sirven para mostrar a la compañía como transparente, que cumple con todos los estándares, que se relaciona de tal manera que tiene impactos favorables en el bienestar social, en el trabajo, en el medio ambiente, en la igualdad de género, entre otras (GRI 2017). Pero lo que vemos es que ambos sellos han sido utilizados de tal forma que las empresas se muestran como responsables y en favor de los derechos laborales, mientras la tercerización se establece como una forma de relación entre los ingenios y los corteros. Es decir, que la aplicación de ambos estándares no necesariamente repercute de manera positiva en la protección de los derechos laborales de los trabajadores de los ingenios.

\section{D.2. La RSE una arena en disputa}

El objetivo de este subcapítulo es entender cómo la RSE se configura como una arena en disputa por los contenidos de los programas y los beneficios a los que puede acceder cada grupo de interés. En primer lugar, la RSE de los ingenios fortalece la división entre trabajadores directos e indirectos al organizar los programas según grupos de interés. Los trabajadores de las empresas de corte no pueden acceder a los programas diseñados para los trabajadores directos de los ingenios; mientras que las empresas de corte, no ofrecen programas que beneficien a sus trabajadores o a la comunidad. En segundo lugar, la RSE abre una serie de canales por medio de los cuales los trabajadores de las empresas de corte 
pueden reclamar a quien consideran su patrón, es decir a los ingenios, la pérdida de condiciones de vida y de trabajo que se da por la tercerización.

Siguiendo a Cross (2016), la organización de los programas de RSE alrededor de grupos de interés es una de las maneras en las que los códigos internacionales, protocolos, directrices y normas de la RSE operan como instrumentos políticos o ideológicos de control que, a su vez, producen individuos, personas y sociedades. De esta forma, lo que aparece como una herramienta de rendición de cuentas y auditoría termina instalando nuevas formas de gobernanza entre los empresarios, los administradores de la RSE y los trabajadores. En este sentido, los encargados de los programas de RSE de los ingenios traducen las numerosas demandas de los trabajadores de distintas áreas de los ingenios en aquello que es posible o imposible y reducen las acciones de la empresa a cuestiones medibles ajustadas a una serie de indicadores. Además, distinguen claramente a qué grupo de interés se ajusta cada actividad.

A pesar de este carácter meramente político de la RSE, Sydow (2016) advierte que la aplicación de soluciones y programas estandarizados, sin tener en cuenta el contexto, oculta el contenido político de las actividades de RSE y los convierte en temas meramente técnicos. En el caso de estudio, esto se refuerza porque las nuevas formas de la RSE se combinan con formas del paternalismo tradicional. Así los beneficios que obtienen los trabajadores y la comunidad no son derechos sino dádivas que la empresa puede quitar a voluntad. Los obstáculos que esto presupone para la organización del colectivo de los trabajadores y la negociación de convenios colectivos de trabajo permiten sostener que, aunque las modalidades de contratación sean legales, no dejan de ser precarias. En este marco, mientras los trabajadores directos obtienen beneficios adicionales por medio de programas de RSE; los corteros tercerizados utilizan los programas de RSE dirigidos a la comunidad y a los proveedores para realizar sus propias demandas.

Antes de profundizar sobre la RSE como una arena en disputa, es importante revisar la forma en que los ingenios fragmentan el conjunto de los trabajadores, se desligan de sus responsabilidades legales mientras que al mismo tiempo mantienen su rol de patrón. Los ingenios establecen un contrato comercial con las empresas de corte, las cuales establecen un contrato de tipo laboral con sus trabajadores. De esta forma, entre el ingenio y los 
trabajadores continúa existiendo una relación con contenido laboral, pero sin las obligaciones que por ley se establecen. Las empresas de corte en este caso son las que deben asumir todas las responsabilidades laborales y cualquier tipo de conflicto que se presente. Así, los ingenios se cuidan de lidiar nuevamente con protestas como las del 2005 y 2008, y al mismo tiempo disponer de los corteros cuando lo necesitan con condiciones flexibles de contratación y despido.

No obstante, el Ministerio de Trabajo reconoció que el oficio de los corteros está íntimamente ligado al ingenio porque los ingenios son los dueños de los terrenos o son lo que tienen los contratos para explotarlos, también son los dueños de las maquinarias que recogen la caña cortada, y definen los horarios y lugares de corte. Estos y otros aspectos indican que los ingenios continúan siendo los patrones. A las observaciones del Ministerio de Trabajo de suma el hecho de que los dueños de las empresas de corte, en ocasiones, son los mismos ingenios. Como El Dorado que es el dueño del 49\% de Servicios de Cosecha Dorado.

Y Centenario Corte, una empresa que en 2015 tenía 401 corteros y aportaba más del $60 \%$ de toda la materia prima que llegaba al ingenio Centenario. El otro $40 \%$ provenía del trabajo realizado por corteros contratados directamente por el ingenio, del corte mecanizado o de otro grupo de contratistas. Para el control de este grupo de trabajadores en El Centenario hay un equipo encargado de hacerle seguimiento a los proveedores. Ellos se aseguran de que empresa de corte "pague la seguridad social de sus trabajadores, les hacen visitas les caen de sorpresa, pues para mirar que haya cumplimiento de la seguridad. Que el trabajador que viene a trabajar aquí con un contratista tenga toda la normatividad laboral" (Stella Galvis: 6 de agosto de 2015).

En este contexto los ingenios utilizan sus planes, programas y directrices de RSE para reconocer a los corteros tercerizados como parte fundamental del funcionamiento del ingenio, sin dejar de marcar sus diferencias con respecto de los trabajadores directos. Asimismo, los discursos y prácticas de RSE les permiten proteger a todos los trabajadores ya sean directos o tercerizados, sin responder a las obligaciones de un contrato laboral. La distinción por la forma de contratación y el grupo de interés al que pertenece según los programas de RSE se refuerza con las narrativas de otredad que diferencian entre los corteros directos que han pasado por los procesos civilizatorios promovidos desde el ingenio, y los 
tercerizados, que aún son vistos como desordenados, vagos y borrachos. Como se evidencia en la entrevista de Salazar sobre los corteros que contrató el ingenio en el 2008 y que han pasado por diferentes etapas de procesos de formación, en comparación con aquellos que continúan tercerizados:

Es totalmente diferente, es un cortero que ya ahorra, es un cortero que ya tiene su casa arregladita, que sus hijos ya están estudiando, que saben que hay que acatar unas reglas, que si yo llego borracho me suspenden, que si yo agredo a otro compañero me despiden [...] Cuando yo empecé decía no podemos seguir atendiendo de a uno en uno, entonces cuando hicimos el levantamiento social nos dimos cuenta que estaban sumamente endeudados, que debían la casa, que debían, yo era cerros de recibos de deudas. No, no podemos seguir pagando deudas tenemos que sentarnos a cogerlos por grupos a mirar en qué es que se están gastando la plata [...] Lo que hicimos fue comprarle nosotros la cartera, ir a ordenarlos y descontarles con una cuota muy bajita para que pagaran su casa, pero sin intereses. Entonces la gente quedó saneada, ya este grupo de 250 y pico de corteros ya no le deben a nadie, ni a nosotros tampoco (Miriam Salazar: 4 de agosto de 2015).

En el caso de El Centenario la distinción se marca porque hay un área de relaciones industriales que se enfoca exclusivamente en los trabajadores tercerizados que están dentro del ingenio. Entonces, aunque acceden de manera diferenciada, los corteros tercerizados pueden disponer, y reclamar, programas o ayudas específicas de los ingenios. Por ejemplo, "les ayudan con libranzas para que tengan convenio con alguna entidad, para que salgan de todas esas deudas" (Ernesto Lopera: 28 de diciembre de 2016). Incluso, "las esposas de los trabajadores así no sean del ingenio, si tienen beneficios con el Colegio de labores. Hay muchas personas, personas que ni siquiera trabajan con el ingenio" (Humberto Sánchez: 16 de octubre de 2015). En ese sentido, los trabajadores tercerizados y sus familias consiguen mejoras en sus condiciones de vida al participar en los programas de RSE dirigidos a los proveedores o a la comunidad.

Sin embargo, los corteros de Centenario Corte van un paso más allá y demandan mejores condiciones laborales ante los encargados de la RSE, resignificando este espacio para poder tramitar sus reclamos. Ellos acuden a las oficinas de Relaciones Industriales del 
ingenio para exigir condiciones similares a las de los trabajadores directos en términos de dotación, de programas y demás servicios que se brindan desde la RSE. Desde el ingenio se observan cierta resistencia, ya que frente a este escenario de disputa Miriam afirma que "ese es el desgaste. Que entiendan que no puede ser igual porque no es la empresa directamente, pero ellos no quieren cambiar" (Miriam Salazar: 4 de agosto de 2015).

Una tercera forma en que los corteros convierten la RSE en una arena en disputa se da con el sindicato de esta empresa de corte, el cual hace demandas para mejorar las condiciones de vida y de trabajo por medio del pliego de peticiones. Así, el sindicato de Servicios de Cosecha Dorado incluyó en su pliego de peticiones al ingenio El Dorado un coliseo cubierto para el municipio donde el ingenio tiene mayor influencia. En ese sentido, las demandas en el marco de los programas de RSE se dirigen a la mejora de las condiciones de vida de la comunidad.

En síntesis, el manejo tecnocrático de la RSE genera un conjunto de los obstáculos a la exigencia de ciertas demandas, a su vez la RSE incide en la despolitización de la relación entre los ingenios y los corteros. En tercer lugar, la división de los programas de RSE según grupo de interés y las narrativas de otredad asociadas a dichos programas refuerzan la distinción de la forma de contratación. No obstante, los corteros tercerizados, y sus familias, logran disputar mejoras en sus condiciones de vida y de trabajo en la misma arena de la RSE. 


\section{E. Conclusiones}

Como se ha visto a lo largo de este trabajo se puede concluir que los ingenios han experimentado diversas formas de tercerización laboral. A su vez, los ingenios estudiados, han manejado la relación con los trabajadores y la comunidad por medio de prácticas paternalistas que limitaron la creación de sindicatos independientes (o con capacidades fuertes de negociación que representen mejoras sustanciales para los trabajadores). Estas prácticas sostuvieron una relación salarial restringida que no permitía al trabajador independizarse del ingenio en el sentido de cubrir por sus propios medios, o por medio de un sistema de seguridad social independiente del ingenio, sus necesidades y deseos y los de su familia (por ejemplo, alimentación, salud, educación, recreación, etc.).

Desde los ingenios se sostuvieron narraciones acerca del otro que legitimaron esa relación salarial restringida, al tiempo que justificaba la intromisión del ingenio en la vida privada de los trabajadores y reducía su capacidad de organización. A pesar de todo esto, hubo dos paros de larga duración, alto impacto y grado de conflictividad en 2005 y 2008. Después de los paros, pero sobre todo tras la entrada en vigencia del TLC, hubo transformaciones que permitieron ciertas mejoras pero no generaron cambios significativos en otros aspectos como la tercerización. La tercerización laboral se combinó con nuevas formas de pensar la relación de las empresas con sus grupos de interés, la RSE, el GRI y el Pacto Global. Los procesos de tercerización también transforman la relación entre los corteros y las empresas, y obstaculizan los reclamos laborales. Ya sin la protección de la legislación laboral, estos deben realizarse en el marco del derecho comercial.

Estas nuevas formas de relación obrero-patronal traen novedades en cuanto al tema de la productividad, de programas que vayan acorde con planes y objetivos que se ciñan a análisis de costos-beneficios, así como la sistematización de las acciones realizadas por las compañías (a pesar de dejar a propósito otras sin sistematizar). Pero al mismo tiempo continúa la arbitrariedad en cuanto a la aplicación de ciertos aspectos, permite que haya una relación directa entre los trabajadores y los empleados de la RSE. No obstante los efectos despolitizadores y de refuerzo de las diferencias y la fragmentación entre los denominados "grupos de interés" (los directos y los tercerizados). El paternalismo al viejo estilo continúa 
y se superpone con otras formas de atención mucho más burocráticas enfocadas en la rentabilidad

No obstante los corteros no asumieron esto así, sino que lo están utilizando para hacer reclamos por mejores condiciones de vida y de trabajo al resignificar los programas y los espacios de RSE. A través del acceso de sus familias a los programas de RSE, las reclamaciones antes la oficina de relaciones industriales y la inclusión del ingenio (que es reconocido como patrón) en el pliego de petición del sindicato de la empresa de corte, por ser el municipio de mayor influencia de la compañía. De esta forma la RSE en el contexto de la tercerización laboral, principalmente de la mano de empresas de corte, se convierte en una arena en disputa.

Cabe resaltar que la RSE opera de manera diferenciada en los dos ingenios analizados. Por un lado, en El Centenario, está muy internalizado el discurso burocrático y mediado por protocolos, directrices e indicadores como mediadores de la relación obrero-patronal. No obstante, como queda en evidencia en el último capítulo, aún persisten antiguas prácticas paternalistas de discrecionalidad, no reporte de todo lo que hacen o nombrar a los trabajadores como tal y no como colaboradores siguiendo los lineamiento de la jerga técnica propia de la RSE.

Por otro lado, en El Dorado queda en evidencia que es aún muy paternalista, que el gerente incluso mantiene la potestad de dar regalos a personas que viven en las comunidades aledañas y que acuden a él, para pedir ayuda. Aun los discursos de RSE no se utilizan con tanta regularidad y se continúan haciendo programas más sencillos como celebraciones de días importantes, en comparación con El Centenario que tiene montados programas especializados de atención a los trabajadores directos y sus familias. Así como una fundación para hacer inversiones que propendan por el desarrollo de la educación en los municipios donde tiene alta incidencia.

La RSE además surge como respuesta a los conflictos entre la empresa y la sociedad puesto que en su accionar las empresas generan una serie de externalidades, de manera directa o indirecta por medio de sus redes de valor, que afectan a la sociedad, por ejemplo impactos ambientales, atracción de migrantes, afectación a los derechos humanos, incumplimiento de la regulación laboral, trabajo infantil, prácticas antisindicales, discriminación y acoso laboral. 
No obstante, esta respuesta es manejada desde el sector empresarial, y se implementa de manera voluntaria para evitar regulaciones vinculantes por parte del estado.

Por último, esta investigación además deja nuevos campos de indagación, asociados al control que los empleados de la RSE adquieren sobre las poblaciones objetivo, como un efecto adverso de la puesta en marcha de dichos programas. Estos efectos adversos que dejan la puesta en marcha de la RSE, son similares a los efectos de la máquina anti-política de Ferguson (1994). La cual, no tiene como fin último alcanzar de manera exitosa el objetivo de entrada del proyecto de desarrollo, pero si los efectos adversos que deja dicho proyecto. Estos efectos adversos, aprueban un ejercicio de poder sobre las poblaciones objetivo que se ejercen a través de la burocracia generada en la administración de los proyectos de desarrollo. Aunque no en todos los casos, pues a pesar de su fuerza las poblaciones objetivo encuentran espacios y formas de ejercer agencia.

La RSE puede actuar, no solo en espacios geográficos sino en otros ámbitos como el jurídico. Ya que, en primera instancia la RSE entra a mediar las relaciones entre las corporaciones y los trabajadores en forma de programas específicos de mejoras de su calidad de vida y la de sus familias y terminan, en algunos casos, dejando efectos como el ensanchamiento del control, por parte de los encargados de los programas, en la vida de los trabajadores. Esta profundización del control se logra a través del ejercicio de la burocracia. 


\section{E. Referencias}

Alacevich, M. (2010). La economía política del Banco Mundial: los primeros años. Bogotá: Mayol Ediciones.

Arbeláez, M., Estacio, A., \& Olivera, M. (2010). Impacto Socioeconómico del sector azucarero colombiano en la economía nacional y regional. Bogotá: La imprenta editores.

Aricarpa, A. R. (2006). Las cooperativas de trabajo asociado en el sector azucarero: Flexibilización o salvajismo laboral. Medellín: Escuela Nacional Sindical.

Basualdo, V. \& Esponda, M, In Morales, D. R., \& Basualdo, V. (2014). La expansión de la tercerización a nivel global a mediados de los años setenta, sus antecedentes históricos y su alcance actual en La tercerización laboral: Orígenes, impacto y claves para su análisis en América Latina. Argentina: Siglo XXI editores.

Basualdo, V. \& Esponda, M, In Morales, D. R., \& Basualdo, V. (2014). La tercerización laboral: Orígenes, impacto y claves para su análisis en América Latina. Argentina: Siglo XXI editores.

Benson, P., \& Kirsch, S. (January 01, 2010). Corporate oxymorons. Dialectical Anthropology, 34, 1, 45-48.

Benson, P., Kirsch, S., Frynas, J., Hann, C., Ribeiro, G., Schoenberger, E., \& Subramanian, A. (1 de January de 2010). Capitalism and the politics of resignation. Current Anthropology, 51(4), 459-486.

Brenner, N., \& Theodore, N. (2002). Cities and the geographies of "actually existing neoliberalism". Antipode, 34 (3), 349-379.

Centro Nacional de Productividad (Colombia), United Nations., \& Unidad de Desarrollo Industrial y Tecnológico. (2002). El conglomerado del azúcar del Valle del Cauca, Colombia. Santiago de Chile: Red de Reestructuración y Competitividad, Unidad de Desarrollo Industrial y Tecnológico, División de Desarrollo Productivo y Empresarial. 
Cross, J. (2016). Detachment as corporate ethic: materializing CSR in the diamond supply The anthropology of corporate social responsibilty. Oxford : Berghahn Books Ltd.

Dolan, C., \& Rajak, D. (2016). The anthropology of corporate social responsibilty. Oxford: Berghahn Books Ltd.

Escuela Nacional Sindical (Colombia). \& Friedrich-Ebert-Stiftung in Kolumbien. (2014). La precariedad laboral en Colombia: Crónicas y reportajes. Bogotá.

Ferguson, J. (1994) The Anti-politics machine. Development and bureaucratic power in Lesotho. The Ecologist, 24, 5, 176-181.

González, F. E. G. (2016 [2014]). Poder y violencia en Colombia. Editorial Pontificia Universidad Javeriana.

Herrera, R. W. (01 de Julio de 2011). Critica del modelo liberal de empresa: Un análisis de la RSE desde la idea de Estado social de derecho. Cuadernos De Administración (Santafé De Bogotá), 24, 43, 157-176

Hurtado, T. \& Urrea-Giraldo, F. (2004). Políticas y Movimiento social negro agrario en el norte del Cauca en Gente negra en Colombia (359-391). Cali: Editorial Lealon.

Kirsch, S. (2014). Coliding Ecologies en Mining capitalism: The relationship between corporations and their critics. California: University of California Press.

Ministerio de Minas y Energía y el Banco Interamericano de Desarrollo (2012). Evaluación del ciclo de vida de la cadena de producción de biocombustible. Medellín: Consorcio CUE.

Mintz, S. W. (1974). Worker in the cane: A Puerto Rican life history. New York: W.W. Norton.

Mintz, S. W. (1985). Sweetness and power: The place of sugar in modern history. New York: Sifton.

Misas, G. (2002). La ruptura de los 90 del gradualismo al colapso. Univ. Nacional de Colombia. 
Observatorio del mercado de trabajo y la seguridad social (2007). Las cooperativas de trabajo asociado en Colombia en Boletín número 10. Universidad Externado de Colombia, Bogotá 10 (1- 29).

Posada, F., \& Posada, J. (1966). La CVC: Un reto al subdesarrollo y al tradicionalismo. Bogotá: Ed. Tercer Mundo.

Ramos, O. G. (1996). Historia de la cultura empresarial en el Valle del Cauca. Cali: Corporación Financiero del Valle.

Ronderos, C. (2011). Responsabilidad social empresarial en la industria de la caña de azúcar en el Valle del río Cauca. Universidad Sergio Arboleda, Bogotá.

Sala de presa Universidad del Rosario (2016). Sala de Prensa Universidad del Rosario. Obtenido de Universidad del Rosario: http://www.urosario.edu.co/sala_de_prensa/Economia/En-Colombia-lainformalidad-laboral-1lega-al-70-en/

Schreier, M. (2014). Qualitative content analysis en U. Flick The SAGE handbook of qualitative data analysis, London: Sage, 170-183.

Restrepo, E. (2002). Políticas de la alteridad: Etnización de "comunidad negra" en el Pacifico sur colombiano. Journal of Latin American Anthropology, 7, 2, 34-58.

Rojas, A. (2006). Poblaciones negras viejas realidades, nuevos desafíos en Deshacer el embrujo alternativas a las políticas del gobierno de Álvaro Uribe Vélez.

Rojas, A. (2014). De la salvación al desarrollo: gente negra, evangelización y extractivismo en el suroccidente colombiano en Revista de Historia comparada. V8 N1 (59-95).

Rojas, A. (2017). Estrategia de localización. Desarrollo, capital y comunidades negras en la región del norte del Cauca. Bogotá: Observatorio de territorios étnicos.

Ronderos, C. (2011). Responsabilidad social empresarial en la industria de la caña de azúcar en el Valle del río Cauca. Universidad Sergio Arboleda, Bogotá.

Scott, James C. Seeing like a state: How certain schemes to improve the human condition have failed. Yale University Press, 1998. 
Subhabrata Banerjee (2008), Corporate Social Responsibility: The Good, the bad and the ugly. Critical Sociology, 34, 1, 51-79.

Sydow, J. (2016). Global Concepts in local concepts: CSR as "Anti-Politics Machine" in the Extractive Sector in Ghana and Perú. En C. Dolan, \& D. Rajak, The anthropology of corporate social responsibilty. Oxford: Berghahn Books Ltd.

Taussig, M. T. (2010). The devil and commodity fetishism in South America. Chapel Hill: University of North Carolina Press.

Urrea Giraldo, F. (2007) La Rápida expansión de las cooperativas de trabajo asociado en Revista Controversia. 188 (119-169)

Urrea Giraldo, F. (2010). Dinámicas de reestructuración productiva- cambios institucionales y políticos y procesos de desregulación de las relaciones asalariadas- el caso colombiano. Series de la Escuela Nacional Sindical

Valero, E.A. (2013) Paternalismo empresarial en la industrialización de Colombia y Venezuela (Doctoral dissertation, Universidad Nacional de Colombia).

Vejar, D. J. (Diciembre 01, 2014). La precariedad laboral, modernidad y modernización capitalista: Una contribución al debate desde América Latina. Trabajo Y Sociedad, 23, 147-168.

Welker, M. (Enero 01, 2009). Corporate Security begins with the community. Mining, the Corporate Social Responsibility Industry, and Environmental Advocacy in Indonesia. Cultural Anthropology Washington-, 24, 1, 142-179.

Willmot, H. (2007). La fuerza es la ignorancia, la esclavitud es la libertad: la gestión de la cultura en las organizaciones modernas en Vigilar y Organizar. Madrid: Siglo XXI.

\section{Referencias legales}

Congreso de la República de Colombia (1931). Ley 134 de 1931. "Sobre sociedades cooperativas". Diario Oficial no. 21866.

Congreso de la República de Colombia (1950). Ley 2663 de 1950. “Sobre Código Sustantivo del Trabajo". Diario Oficial no. 27407. 
Congreso de la República de Colombia (1988). Ley 79 de 1988. "Por la cual se actualiza la Legislación Cooperativa”. Diario Oficial no. 38648.

Congreso de la República de Colombia (1990). Decreto 468 de 1990. "Por la cual se reglamenta la Ley 79 de 1988”.

Congreso de la República de Colombia (1990). Ley 50 de 1990. "Por la cual se introducen reformas al Código Sustantivo del Trabajo y se dictan otras disposiciones”.

Congreso de la República de Colombia (1992). Decreto 1100 de 1992. "Por la cual se reglamenta la Ley 10 de 1991”. Diario Oficial no. 40492.

Congreso de la República de Colombia (2010). Ley 1429 de 2010. "Por la cual se expide la Ley de Formalización y Generación de Empleo”. Diario Oficial no. 47937.

Ministerio del Trabajo (2016). Resolución 583 de 2016. "Por el cual se adiciona al título 3 de la parte 2 del libro 2 del Decreto 1072 de 2015, Decreto Único Reglamentario del Sector Trabajo, un capítulo 2 que reglamenta el artículo 63 de la Ley 1429 de 2010 y el artículo 74 de la Ley 1753 de 2015”.

Ministerio del Trabajo (2016). Resolución 5670 de 2016. "Por el cual se establecen los lineamiento respecto de la inspección, vigilancia y control que se adelante frente al contenido de los artículos 74 de la ley 1753 de 2015 y 63 de la ley 1429 de 2010, así como sus decretos reglamentarios".

Ministerio del Trabajo (2017). Resolución 2468 de 2017. Coordinadora Unidad de investigaciones especiales: Katly Jinett Copete Hidalgo.

Ministerio del Trabajo (2016). Resolución 5670 de 2016. "Por el cual se establecen lineamientos respecto de la inspección, vigilancia y control que se adelante frente al contenido de los artículos 74 de la ley 1753 de 2015 y 63 de la ley 1429 de 2010, así como sus decretos reglamentarios".

\section{Otras Referencias}

Asocaña (2014). El Sector Azucarero Colombiano, más que azúcar, una fuente de energía renovable para el país. Asocaña, Cali. 
Asocaña (2017). Informe anual Asocaña 2016 - 2017. Anual, Asocaña, Cali.

Asocaña (2017). Más que azúcar, una fuente de energía renovable para el país. Asocaña, Cali

Asocaña (2016). Aspectos Generales del Sector Azucarero Colombiano 2015-2016. Anual, Asocaña, Cali.

Asocaña (2015). Aspectos generales del sector azucarero: el dulce sabor del azúcar de Colombia es progreso 2013-2014. Anual, Asocaña, Cali.

El Centenario (2015). Informe de Sostenibilidad 2015. El Centenario. Candelaria: Departamento de Comunicaciones y Publicidad El Centenario.

El Centenario (2014). Informe de Sostenibilidad 2014. El Centenario. Candelaria: Departamento de Comunicaciones y Publicidad El Centenario.

El Centenario (2013). Informe de Sostenibilidad 2013. El Centenario. Candelaria: Departamento de Comunicaciones y Publicidad El Centenario.

El Centenario (2012). Informe de Sostenibilidad 2012. El Centenario. Candelaria: Departamento de Comunicaciones y Publicidad El Centenario.

El Centenario (2011). Informe de Sostenibilidad 2011. El Centenario. Candelaria: Departamento de Comunicaciones y Publicidad El Centenario.

El Dorado (2015). Informe de Sostenibilidad 2015. Ingenio Dorado. Guacarí.

El Dorado (2014). Informe de Sostenibilidad 2014. Ingenio Dorado. Guacarí.

El Dorado (2013). Informe de Sostenibilidad 2014. Ingenio Dorado. Guacarí.

El Dorado (2012). Informe de Sostenibilidad 2014. Ingenio Dorado. Guacarí.

El Dorado (2011). Informe de Sostenibilidad 2014. Ingenio Dorado. Guacarí.

El Dorado (2010). Informe de Sostenibilidad 2014. Ingenio Dorado. Guacarí. 
Global Reporting Initiave (2017). KPMG Survey of Corporate Responsibility Reporting 2017. Tomado de https://www.globalreporting.org/information/aboutgri/Pages/default.aspx el 19 de marzo de 2018.

Procaña (SD). Historia de Procaña. Tomado de http://www.procana.org/new/quienessomos/historia-de-proca\%C3\%B1a.html el 14 de noviembre de 2017.

\section{Prensa}

ARL Sura (2017). Pilas con el manguito rotador. Tomado de https://www.arlsura.com/index.php/noticias/173-noticias/2020-pilas-con-elmanguito-rotador el 25 de septiembre de 2017.

El País Cali (2017) Fiscalía tiene la lupa sobre 5 mil casos de corrupción en el Valle. Tomado de http://www.elpais.com.co/judicial/fiscalia-tiene-la-lupa-sobre-5-mil-casos-decorrupcion-en-el-valle.html el 25 de septiembre de 2017

El País Cali (2016) Proyecto de ley busca que se deje de usar el préstamo conocido como 'gota a gota'. Tomado de http://www.elpais.com.co/economia/proyecto-de-leybusca-que-se-deje-de-usar-el-prestamo-conocido-como-gota-a-gota.html el 25 de septiembre de 2017

El País Cali (2014) Las ARL desconocen las enfermedades laborales: Abogada laboral. Tomado de http://www.elpais.com.co/colombia/las-arl-desconocen-lasenfermedades-laborales-abogada-laboral.html el 25 de septiembre de 2017

El Tiempo (2017). Bioetanol de caña. Tomado de http://www.eltiempo.com/opinion/columnistas/juan-carlos-mira/bioetanol-de-canajuan-carlos-mira-86808 el 25 de septiembre de 2017

La FM (2017). Nueva Tasa de Usura. Tomado de http://www.lafm.com.co/economia/nueva-

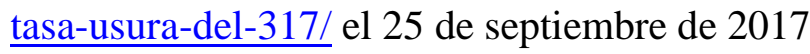

Portafolio (2016). El Agro se está quedando sin gente que trabaje en la finca. Tomado de http://www.portafolio.co/economia/el-agro-se-esta-quedando-sin-gente-que-trabaje$\underline{\text { en-la-finca-49943 }} 9$ el 25 de septiembre de 2017 
Portafolio (2012). Etanol en Colombia es uno de los más caros del mundo. Tomado de http://www.portafolio.co/economia/finanzas/etanol-colombia-caros-mundo-98874 el 25 de septiembre de 2017

Superintendencia de industria y comercio (2015) Superindustria ratifica sanciones a empresas y directivos del sector azucarero por cartelización empresarial. Tomado de http://www.sic.gov.co/noticias/superindustria-ratifica-sanciones-a-empresas-ydirectivos-del-sector-azucarero-por-cartelizacion-empresarial 